QA: QA

000-30R-MGR0-00400-000-001

March 2005

\title{
Nuclear Safety Design Bases for License Application
}

Prepared for:

U.S. Department of Energy

Office of Civilian Radioactive Waste Management

Office of Repository Development

1551 Hillshire Drive

Las Vegas, Nevada 89134-6321

Prepared by:

Bechtel SAIC Company, LLC

1180 Town Center Drive

Las Vegas, Nevada 89144

Under Contract Number

DE-AC28-01RW12101 


\section{DISCLAIMER}

This report was prepared as an account of work sponsored by an agency of the United States Government. Neither the United States Government nor any agency thereof, nor any of their employees, nor any of their contractors, subcontractors or their employees, makes any warranty, express or implied, or assumes any legal liability or responsibility for the accuracy, completeness, or any third party's use or the results of such use of any information, apparatus, product, or process disclosed, or represents that its use would not infringe privately owned rights. Reference herein to any specific commercial product, process, or service by trade name, trademark, manufacturer, or otherwise, does not necessarily constitute or imply its endorsement, recommendation, or favoring by the United States Government or any agency thereof or its contractors or subcontractors. The views and opinions of authors expressed herein do not necessarily state or reflect those of the United States Government or any agency thereof. 
Originator:

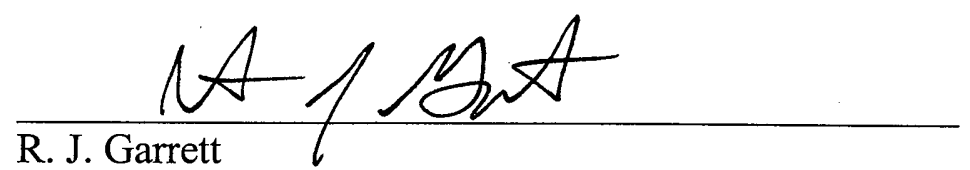

R. J. Garrett

Preclosure Safety Engineer

Checker:

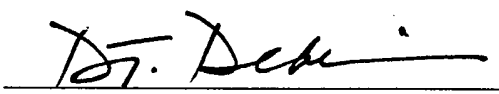

D. T. Dexheimer

Preclosure Safety Engineer

Quality Engineering Representative:

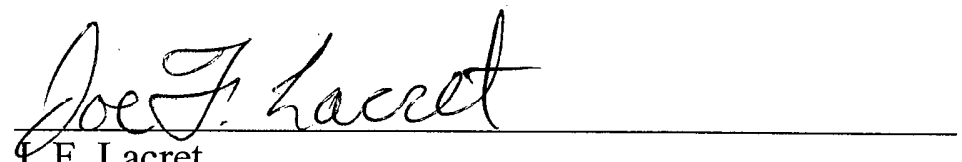

9. F. Lacret

Quality Assurance Engineer

Responsible Manager:

For Chen

D. C. Richardson

Manager, Preclosure Safety Analysis
$03 / 08 / 05$

Date

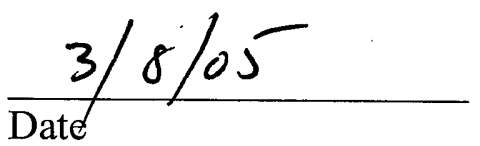

$3 / 08 / 2005$

Date

000-30R-MGR0-00400-000-001

iii

March 2005 


\section{INTENTIONALLY LEFT BLANK}




\section{CHANGE HISTORY}

\section{Revision Interim Effective Number Change No. Date}

00

N/A N/A

N/A N/A

\section{Description of Change}

Initial issue as 000-30R-MGR0-00400-000-000. This initial issue supersedes TDR-MGR-RL-000006. The document identifier was changed to conform to the document numbering methodology for engineering documents. This document is a complete revision of TDR-MGR-RL-000006.

Complete revision to incorporate design changes to the existing repository design. These design changes resulted in additions and deletions to the list of structures, systems, and components classified as important to safety. These structures, systems, and components that are important to safety require nuclear safety design bases or changes to the existing design bases. 


\section{INTENTIONALLY LEFT BLANK}




\section{CONTENTS}

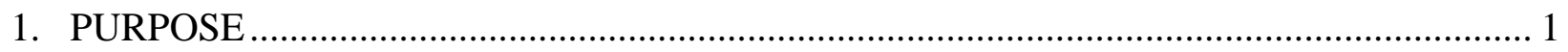

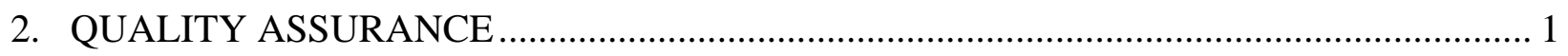

3. USE OF SOFTWARE ………………………….................................................. 1

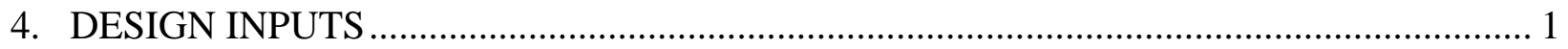

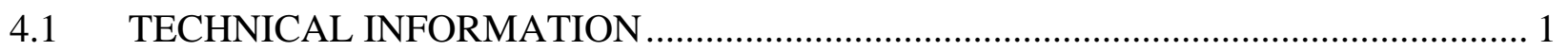

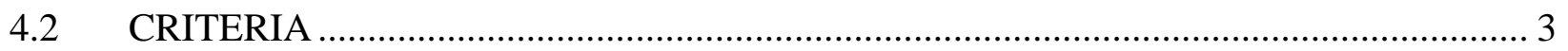

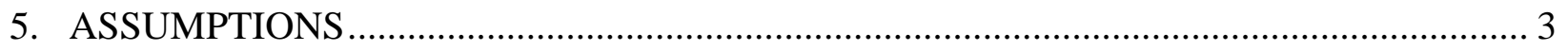

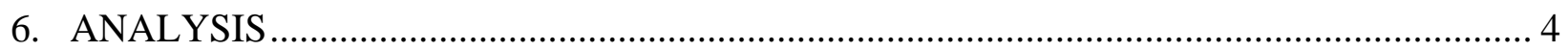

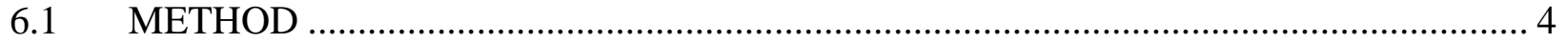

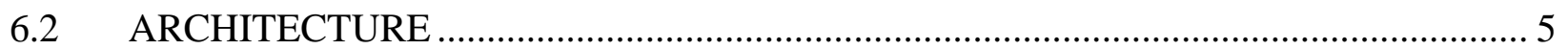

6.3 CATEGORIZATION OF EVENT SEQUENCES ……............................................... 7

6.4 CLASSIFICATION OF STRUCTURES, SYSTEMS, AND COMPONENTS.................. 7

6.5 EVENT SEQUENCE CONSEQUENCE ANALYSIS .................................................... 7

6.6 DEVELOPMENT OF DESIGN BASES .................................................................. 7

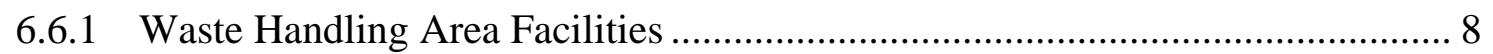

6.6.1.1 Balance of Plant Facility ………………………………………..... 8

6.6.1.2 Canister Handling Facility............................................................... 8

6.6.1.3 Dry Transfer Facility ……………………………………………. 8

6.6.1.4 Fuel Handling Facility ..................................................................... 9

6.6.1.5 Subsurface Facility ………………………………...................... 9

6.6.1.6 Transportation Cask Receipt/Return Facility ..................................... 10

6.6.1.7 Warehouse and Non-Nuclear Receipt Facility ……............................ 10

6.6.2 Waste Process and Infrastructure Systems .......................................................... 10

6.6.2.1 Cask/MSC/WP Preparation System ............................................... 10

6.6.2.2 Cask Receipt and Return System ................................................. 11

6.6.2.3 Communications System ................................................................. 11

6.6.2.4 Digital Control and Management Information System ....................... 11

6.6.2.5 DOE and Commercial Waste Package System ................................... 11

6.6.2.6 Electrical Power System...................................................................... 11

6.6.2.7 Electrical Support System .......................................................... 12

6.6.2.8 Emplacement and Retrieval System................................................... 12

6.6.2.9 Environmental/Meteorological Monitoring System............................ 12

6.6.2.10 Fire Protection System ……………………………......................... 13

6.6.2.11 HVAC Plant Heating and Cooling System ......................................... 13

6.6.2.12 Low-Level Radioactive Waste Generating System.............................. 13

6.6.2.13 Low-Level Radioactive Waste Management System........................... 13

6.6.2.14 Naval Spent Nuclear Fuel Waste Package System ............................. 13 
6.6.2.15 Non-Nuclear Handling System .......................................................... 14

6.6.2.16 Non-Radiological Waste Management System................................... 14

6.6.2.17 Plant Services System ................................................................... 14

6.6.2.18 Radiation/Radiological Monitoring System....................................... 14

6.6.2.19 Remediation System...................................................................... 14

6.6.2.20 Safeguards and Security System ………………............................. 15

6.6.2.21 SNF Aging System ........................................................................ 15

6.6.2.22 SNF/HLW Transfer System ......................................................... 15

6.6.2.23 Subsurface Ventilation System ........................................................ 15

6.6.2.24 Surface Industrial HVAC System ................................................... 15

6.6.2.25 Surface Nuclear HVAC System .................................................... 16

6.6.2.26 Waste Package Closure System ......................................................... 16

6.7 OTHER ITEMS IMPORTANT TO SAFETY …………………………...................... 16

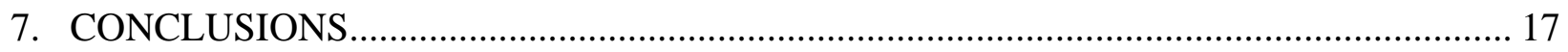

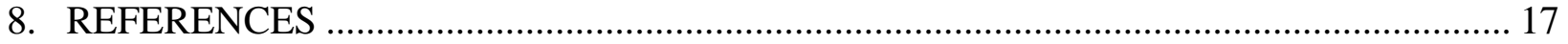

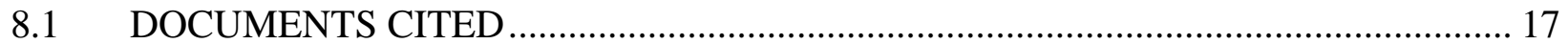

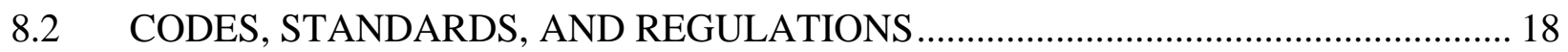

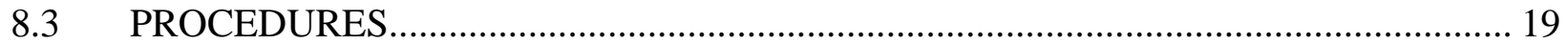

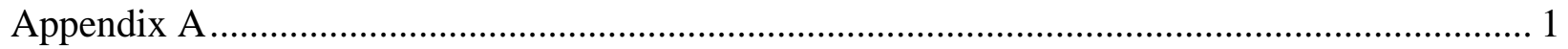

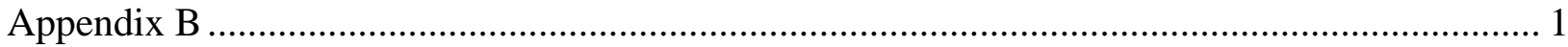

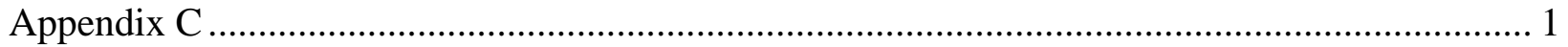




\section{TABLES}

Page

A-I. Nuclear Safety Design Bases of Facilities .................................................................. A-1

A-II. Nuclear Safety Design Bases of Systems and Subsystems ........................................ A-13

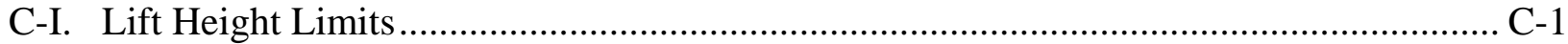




\section{INTENTIONALLY LEFT BLANK}




\section{ACRONYMS}

CHF Canister Handling Facility

DOE U.S. Department of Energy

DTF Dry Transfer Facility

FHF Fuel Handling Facility

HEPA high-efficiency particulate air

HLW high-level radioactive waste

HVAC heating, ventilation, and air-conditioning

ITS important to safety

ITWI important to waste isolation

MCO multicanister overpack

MSC monitored geologic repository site-specific cask

SC safety category

SNF spent nuclear fuel

SSC structure, system, or component

SSCs structures, systems, and components

TCRRF Transportation Cask Receipt and Return Facility

WNNRF Warehouse and Non-Nuclear Receipt Facility

WP waste package 


\section{INTENTIONALLY LEFT BLANK}




\section{PURPOSE}

The purpose of this report is to identify and document the nuclear safety design requirements that are specific to structures, systems, and components (SSCs) of the repository that are important to safety (ITS) during the preclosure period and to support the preclosure safety analysis and the license application for the high-level radioactive waste (HLW) repository at Yucca Mountain, Nevada. The scope of this report includes the assignment of nuclear safety design requirements to SSCs that are ITS and does not include the assignment of design requirements to SSCs or natural or engineered barriers that are important to waste isolation (ITWI).

These requirements are used as input for the design of the SSCs that are ITS such that the preclosure performance objectives of 10 CFR 63.111 [DIRS 156605] are met. The natural or engineered barriers that are important to meeting the postclosure performance objectives of 10 CFR 63.113 [DIRS 156605] are identified as ITWI. Although a structure, system, or component (SSC) that is ITS may also be ITWI, this report is only concerned with providing the nuclear safety requirements for SSCs that are ITS to prevent or mitigate event sequences during the repository preclosure period.

\section{QUALITY ASSURANCE}

As established using information presented in Section 2 of Quality Assurance Requirements and Description (DOE 2004 [DIRS 171539]), this report is subject to quality assurance program requirements because the design bases that are identified are applicable to items classified as ITS as defined by 10 CFR 63.2 [DIRS 156605]. This report was developed in accordance with procedures LP-3.11Q-BSC, Technical Reports and AP-3.13Q, Design Control. Input data are identified and tracked in accordance with LP-3.15Q-BSC, Managing Technical Product Inputs.

\section{USE OF SOFTWARE}

No software required to be qualified under LP-SI.11Q-BSC, Software Management, was used for any part of this analysis. The text of this report is printed using Microsoft Word and is exempted from the requirements of LP-SI.11Q-BSC per Section 2.1.1 of the procedure.

\section{DESIGN INPUTS}

\subsection{TECHNICAL INFORMATION}

4.1.1. In this analysis the acronym for the Dry Transfer Facility (DTF) represents both DTF 1 and DTF 2 and implies that the same systems and components are located within both DTF 1 and DTF 2. Basis: Two identical DTFs are planned. Initially, only one will be constructed and operated. Throughput requirements will determine the timing of construction and operation of the second DTF (BSC 2004e [DIRS 167232], Section 1.1).

4.1.2 Safety Classification of SSCs and Barriers (BSC 2005a [DIRS 171668], Table A-1) establishes the safety classification of the SSCs that are ITS. Basis: This input is appropriate for use because it represents the latest safety classification information available for this report. 
4.1.3 Categorization of Event Sequences for License Application (BSC 2005b [DIRS 171429], Section 7) establishes the categorization (as Category 1, Category 2, or Beyond Category 2) of the internal and external event sequences that may occur before permanent closure of the repository at Yucca Mountain. Basis: This input is appropriate for use because it represents the latest event sequence categorization information available for this report.

4.1.4 Preclosure Consequence Analyses for License Application (BSC 2005c [DIRS 171607], Section 7) describes the SSCs relied upon for prevention or mitigation of identified event sequences. Basis: This input is appropriate for use because it provides the consequences of potential event sequences and identifies the SSCs required to mitigate the consequences of event sequences in order to comply with the performance objectives of 10 CFR Part 63 [DIRS 156605].

4.1.5 Fire-Induced Event Sequence Analysis (BSC 2004c [DIRS 171488], Section 5) describes the SSCs relied upon for prevention or mitigation of identified fire-induced event sequences. Basis: This input is appropriate for use because it provides the basis for design requirements that are required to mitigate the consequences of fire-induced event sequences in order to comply with the performance objectives of 10 CFR Part 63 [DIRS 156605].

4.1.6 Extreme Wind/Tornado/Tornado Missile Hazard Analysis (BSC 2004d [DIRS 171471], Section 9) describes the SSCs relied upon for prevention or mitigation of identified event sequences. Basis: This input is appropriate for use because it provides the basis for design requirements that are required to mitigate the consequences of event sequences associated with extreme winds, tornadoes, and tornado missile hazards in order to comply with the performance objectives of 10 CFR Part 63 [DIRS 156605].

4.1.7 Monitored Geologic Repository External Events Hazards Screening Analysis (BSC 2004b [DIRS 167266], Section 6) describes the SSCs relied upon for prevention or mitigation of identified event sequences. Basis: This input is appropriate for use because it provides the basis for design requirements that are required to mitigate the consequences of event sequences associated with external events in order to comply with the performance objectives of 10 CFR Part 63 [DIRS 156605].

4.1.8 Frequency Analysis of Aircraft Hazards for License Application (BSC 2005d [DIRS 171786], Section 5) describes the SSCs relied upon for prevention or mitigation of identified event sequences. Basis: This input is appropriate for use because it provides the basis for the design requirements associated with aircraft hazards that are required to prevent or mitigate the consequences of event sequences associated with aircraft hazards in order to comply with the performance objectives of 10 CFR Part 63 [DIRS 156605].

4.1.9 Reliability Analysis of the Electrical Power Distribution System to Selected Portions of the Nuclear HVAC System (BSC 2004f [DIRS 171490], Table 9) describes the SSCs relied upon for prevention or mitigation of identified event sequences. Basis: This input is appropriate for use because it provides the basis for the design requirements 
that are required to prevent or mitigate the consequences of event sequences associated with the electrical power system in order to comply with the performance objectives of 10 CFR Part 63 [DIRS 156605].

4.1.10 Seismic Analysis for Preclosure Safety (BSC 2004a [DIRS 171470], Section 4) describes the functions of SSCs relied upon for prevention or mitigation of identified event sequences. Basis: This input is appropriate for use because it provides the basis for the design requirements that are required to prevent or mitigate the consequences of event sequences associated with seismic events in order to comply with the performance objectives of 10 CFR Part 63 [DIRS 156605].

4.1.11 SNF Aging System Safety Study (Cogema. 2004 [DIRS 171793], Section 6) describes the functions of SSCs relied upon for prevention or mitigation of identified event sequences. Basis: This input is appropriate for use because it provides the basis for the design requirements that are required to prevent or mitigate the consequences of event sequences associated with the SNF Aging System in order to comply with the performance objectives of 10 CFR Part 63 [DIRS 156605].

\subsection{CRITERIA}

\section{Federal Regulations}

The safety classification criteria used in this report are based on the performance objectives stated in 10 CFR 63.111 [DIRS 156605]. Transportation casks received at the repository comply with requirements of 10 CFR 71.55 [DIRS 104091], which states that casks are to be subcritical even with most reactive credible configuration of fissile material and moderation to the most reactive credible extent, and the design bases of 10 CFR 71.73 [DIRS 104091]. Event sequence categorization methodology is based on the 10 CFR 63.2 definition of event sequence.

\section{ASSUMPTIONS}

5.1 System architecture is established by "Facility, Equipment and System Names for Use in the SAR” (Lucas 2004 [DIRS 170073]). Rationale: This input is appropriate for use because it represents the latest design information and system architecture available for this report.

5.2 Although the Remediation Facility is included in the system architecture provided in Lucas (2004 [DIRS 170073]), it is assumed to be included as an integral part of the DTF and will not exist as a separate facility. Rationale: The Remediation Facility is integrated within the DTF and provides the space, layout, structures, and embedded systems needed to recover from off-normal conditions during waste-handling operations (e.g., a damaged transportation cask, fuel form, or waste package [WP]). 


\section{ANALYSIS}

\subsection{METHOD}

A distinction is made between the repository design bases and the 10 CFR 63.2 [DIRS 156605] design bases for SSCs that are ITS. All SSCs have design bases; however, only SSCs that are ITS have design bases as defined by 10 CFR 63.2. These 10 CFR 63.2 design bases are required, pursuant to 10 CFR 63.112 [DIRS 156605], to be included in the preclosure safety analysis of the license application for a repository at Yucca Mountain.

The preclosure safety analysis of the license application provides a safety assessment of the 10 CFR 63.2 repository design bases. The 10 CFR 63.2 design bases and the supporting design information are subjected to design control and the other quality assurance criteria of 10 CFR 63.142 [DIRS 156605].

The methodology for developing the 10 CFR 63.2 design bases are summarized in the following paragraphs.

The Category 1, Category 2, and Beyond Category 2 event sequences derived from the internal, external, and other applicable hazards analyses (such as fire hazards analysis, aircraft crash hazards analysis, etc.) are identified. The list of Category 1, Category 2, and Beyond Category 2 event sequences form a part of the repository licensing bases and appear in the license application. Each Category 1, Category 2, and Beyond Category 2 event sequence involves SSCs that are evaluated within the preclosure safety analysis to assess the likelihood and consequences of an event sequence leading to a dose that exceeds the 10 CFR Part 63 [DIRS 156605] preclosure performance objectives. These SSCs may change as the design matures. Changes in the list of event sequences result in a reassessment of affected SSCs and associated 10 CFR 63.2 design bases. Design iterations, design improvements, or design modifications could potentially lead to changes in the list of event sequences and associated SSCs throughout the licensing process and beyond.

Compliance with the 10 CFR Part 63 performance objectives for Category 1 and Category 2 event sequences is significantly different for each category. Category 1 event sequence compliance assessments are based on annual performance requirements that require an aggregation of releases. A Category 2 event sequence compliance assessment is made on a perevent basis. No aggregation of releases is made for Category 2 event sequences. Because of these compliance differences, the design bases for SSCs that are ITS involved in Category 2 event sequences are developed before the design bases associated with the Category 1 event sequences. ITS SSCs may be required to ensure that an event sequence is categorized as Beyond Category 2.

The set of SSCs that has been classified as ITS based on the Category 1 and Category 2 event sequences is identified. In addition, those SSCs credited for ensuring that an event sequence is categorized as Beyond Category 2 are identified. These SSCs that have been classified as ITS require 10 CFR 63.2 design bases to be established. 
A single SSC is then chosen from the set of SSCs classified as ITS and the Category 1, Category 2, and Beyond Category 2 event sequences that credit the function of that SSC are identified from the applicable supporting analyses.

For the selected SSC that is ITS, the Category 2 and Beyond Category 210 CFR 63.2 design bases are developed. This selection process is repeated until the SSCs that are ITS have 10 CFR 63.2 design bases developed for each of the Category 2 and Beyond Category 2 event sequences.

After the design bases for the Category 2 and Beyond Category 2 event sequences are identified, an SSC that is ITS for meeting the Category 1 performance objective is selected. The 10 CFR 63.2 design bases for the SSC that is ITS that meet the 10 CFR Part 63 preclosure performance objectives for Category 1 event sequences are then selected. This process is repeated until 10 CFR 63.2 design bases are established for the SSCs that are ITS in the Category 1 event sequences.

\subsection{ARCHITECTURE}

The repository is comprised of the following facilities (Lucas 2004 [DIRS 170073]):

1. $\quad$ Balance of Plant Facility

2. Canister Handling Facility (CHF)

3. DTF

4. $\quad$ Fuel Handling Facility (FHF)

5. Subsurface Facility

6. Transportation Cask Receipt and Return Facility (TCRRF)

7. Warehouse and Non-Nuclear Receipt Facility (WNNRF).

Although the Remediation Facility is included in the system architecture provided in "Facility, Equipment and System Names for Use in the SAR" (Lucas 2004 [DIRS 170073]), it has since been included as an integral part of the DTF and does not exist as a separate facility (Assumption 5.2).

Repository systems are subdivided into process systems and infrastructure systems. Process systems include systems that involve primary processes in the waste handling and waste isolation systems while the infrastructure systems are those systems that are needed to provide support to the process systems and the facilities. Process and infrastructure systems exist and operate in multiple facilities.

The repository waste handling systems are evaluated to determine the applicability of Category 1, Category 2, and Beyond Category 2 event sequences associated with preclosure operations (BSC 2005b [DIRS 171429]). The Balance of Plant facilities have no Category 1, Category 2, or Beyond Category 2 event sequences associated with preclosure operations (BSC 2005b [DIRS 171429]). The remaining repository facilities and the repository process systems that are present in these facilities include the following (Lucas 2004 [DIRS 170073]):

- Transportation Cask Receipt/Return Facility

- Cask Receipt/Return System 
- Warehouse and Non-Nuclear Receipt Facility

- DOE and Commercial Waste Package System

- Naval Spent Nuclear Fuel Waste Package System

- Non-Nuclear Handling System

- Dry Transfer Facility

- DOE and Commercial Waste Package System

- Naval Spent Nuclear Fuel Waste Package System

- Cask Receipt/Return System

- Non-Nuclear Handling System

- Cask/MSC/WP Preparation System

- SNF/HLW Transfer System

- Waste Package Closure System

- Remediation System

- Emplacement and Retrieval System

- SNF Aging System

- Canister Handling Facility

- DOE and Commercial Waste Package System

- Naval Spent Nuclear Fuel Waste Package System

- Cask Receipt/Return System

- Non-Nuclear Handling System

- Cask/MSC/WP Preparation System

- SNF/HLW Transfer System

- Waste Package Closure System

- Emplacement and Retrieval System

- SNF Aging System

- Fuel Handling Facility

- DOE and Commercial Waste Package System

- Naval Spent Nuclear Fuel Waste Package System

- Cask Receipt/Return System

- Non-Nuclear Handling System

- Cask/MSC/WP Preparation System

- SNF/HLW Transfer System

- Waste Package Closure System

- Emplacement and Retrieval System

- SNF Aging System

- Subsurface Facility

- DOE and Commercial Waste Package System

- Naval Spent Nuclear Fuel Waste Package System

- Emplacement and Retrieval System

- SNF Aging System 
The applicable repository facility and process system SSCs provided in this report are presented with their corresponding 10 CFR 63.2 design bases.

\subsection{CATEGORIZATION OF EVENT SEQUENCES}

An event sequence is defined by the U.S. Nuclear Regulatory Commission to be "a series of actions and/or occurrences within the natural and engineered components of a geologic repository operations area that could potentially lead to exposure of individuals to radiation” (10 CFR 63.2). Event sequences that are "expected to occur one or more times before permanent closure of the geologic repository operations area are referred to as Category 1 event sequences" (10 CFR 63.2). "Other event sequences that have at least one chance in 10,000 of occurring before permanent closure are referred to as Category 2 event sequences” (10 CFR 63.2). Less likely event sequences are considered Beyond Category 2. An event that has no potential for "exposure of individuals to radiation” is not considered an event sequence.

The initial step of the process for determining the 10 CFR Part 63.2 design bases involves determining the Category 1, Category 2, and Beyond Category 2 event sequences. These event sequences are identified in the internal, external, and other applicable hazards analyses. Categorization of Event Sequences for License Application (BSC 2005b [DIRS 171429]) establishes the categorization (as Category 1, Category 2, or Beyond Category 2) of the internal and external event sequences that may occur before permanent closure of the repository at Yucca Mountain.

\subsection{CLASSIFICATION OF STRUCTURES, SYSTEMS, AND COMPONENTS}

Safety Classification of SSCs and Barriers (BSC 2005a [DIRS 171668]) establishes the safety classification of the repository SSCs. If an SSC is determined to be ITS or ITWI, then it is classified as safety category (SC). An SSC can be ITS, ITWI, both, or neither. If an SSC is neither ITS nor ITWI, it is classified as Non-SC. The safety classifications of the repository SSCs, as established in Safety Classification of SSCs and Barriers (BSC 2005a [DIRS 171668]), are reproduced in the tables found in Appendix A of this analysis. The set of SSCs that have been classified as ITS based on the Category 1 and Category 2 event sequences, as well as those SSCs credited for ensuring that an event sequence is categorized as Beyond Category 2, are identified.

\subsection{EVENT SEQUENCE CONSEQUENCE ANALYSIS}

The worker and offsite radiation doses were calculated in Preclosure Consequence Analyses for License Application (BSC 2005c [DIRS 171607], Section 7) for the event sequences identified in Categorization of Event Sequences for License Application (BSC 2005b [DIRS 171429], Section 7). In addition, any mitigative functions performed by ITS SSCs that are credited in the dose calculations are identified (such as high-efficiency particulate air [HEPA] filters).

\subsection{DEVELOPMENT OF DESIGN BASES}

The development of the 10 CFR 63.2 design bases follows the methodology described in Section 6.1 using the inputs described in Section 4.1. 
The repository facilities, and the repository process systems that are present in these facilities, are listed in the following subsections based on the repository architecture described in Section 6.2. The facilities and systems that have Category 1 or Category 2 event sequences that require SSCs to perform prevention or mitigation functions are identified. In some instances, 10 CFR 63.2 design bases are developed for SSCs that provide prevention functions to ensure that the frequency of an event sequence is Beyond Category 2.

The 10 CFR 63.2 design bases (the nuclear safety design bases) for the repository facilities, systems, subsystems, and selected SSCs that are developed using the methodology described in Section 6.1 are presented in Tables A-I and A-II of Appendix A.

\subsubsection{Waste Handling Area Facilities}

The repository facilities include the following: the Balance of Plant Facility, CHF, DTF, FHF, Subsurface Facility, TCRRF, and the WNNRF (Lucas 2004 [DIRS 170073]). The safety categories for these facilities are shown in Attachment A of Safety Classification of SSCs and Barriers (BSC 2005a [DIRS 171668]).

\subsubsection{Balance of Plant Facility}

As established by Categorization of Event Sequences for License Application (BSC 2005b [DIRS 171429], Section 7), there are no Category 1 or Category 2 event sequences that require SSCs in the facilities that comprise the Balance of Plant Facility to perform prevention or mitigation functions. The switchgear facility contains portions of the electrical power system that are ITS. Although the structure contains ITS components, there are no event sequences identified that prevent the ITS components from performing their ITS function. No Balance of Plant facility is required to function to protect an ITS or ITWI SSC or natural or engineered barrier. The safety category of the system is Non-SC (BSC 2005a [DIRS 171668], Attachment A). There are no nuclear safety design bases associated with the Balance of Plant Facility.

\subsubsection{Canister Handling Facility}

As established by Categorization of Event Sequences for License Application (BSC 2005b [DIRS 171429], Section 7), there are Category 2 event sequences that could occur in this facility and there are features of the facility that are ITS for prevention or mitigation of event sequences. The Seismic Analysis for Preclosure Safety (BSC 2004a [DIRS 171470], Attachment III) has identified potential seismically initiated failures that could lead to undesired consequences. This facility contains SSCs that are ITS; it does not contain SSCs or natural or engineered barriers that are ITWI. The safety category of this facility is SC (BSC 2005a [DIRS 171668], Attachment A). Table A-I in Appendix A presents the nuclear safety design bases associated with the CHF.

\subsubsection{Dry Transfer Facility}

As established by Categorization of Event Sequences for License Application (BSC 2005b [DIRS 171429], Section 7) and Preclosure Consequence Analysis for License Application (BSC 2005c [DIRS 171607], Section 7), there are Category 1 and Category 2 event sequences that could occur in this facility and there are features of the facility that are ITS for prevention or mitigation of event sequences. Seismic Analysis for Preclosure Safety (BSC 2004a [DIRS 171470], 
Attachment III) has identified potential seismically initiated failures that could lead to undesired consequences. This facility contains SSCs that are ITS; it does not contain SSCs or natural or engineered barriers that are ITWI. The safety category of this facility is SC (BSC 2005a [DIRS 171668], Attachment A). Table A-I in Appendix A presents the nuclear safety design bases associated with the DTF.

\subsubsection{Fuel Handling Facility}

As established by Categorization of Event Sequences for License Application (BSC 2005b [DIRS 171429], Section 7) and the Preclosure Consequence Analysis for License Application (BSC 2005c [DIRS 171607], Section 7), there are Category 1 and Category 2 event sequences that could occur in this facility and there are features of the facility that are ITS for prevention or mitigation of event sequences. The Seismic Analysis for Preclosure Safety (BSC 2004a [DIRS 171470], Attachment III) has identified potential seismically initiated failures that could lead to undesired consequences. This facility contains SSCs that are ITS; it does not contain SSCs or natural or engineered barriers that are ITWI. The safety category of this facility is SC (BSC 2005a [DIRS 171668], Attachment A). Table A-I in Appendix A presents the nuclear safety design bases associated with the FHF.

\subsubsection{Subsurface Facility}

The Subsurface Facility consists of the emplacement drifts, subsurface development, and postemplacement subsystems (BSC 2005a [DIRS 171668], Section 6.3.1.5). In this report, the Subsurface Facility and its three component subsystems are considered separately in the development of nuclear safety design bases.

The size and layout of the emplacement drifts component of the Subsurface Facility ensure that performance complies with rockfall modeling (preclosure and postclosure) and drift modeling (postclosure) because they provide the rock properties and emplacement drifts layout and dimensions for the rockfall analysis. The size and layout of drifts is both ITS and ITWI. Nonemplacement openings of the Subsurface Facility provide the size properties consistent with rockfall modeling for preclosure. A change of the size of the nonemplacement openings may allow a larger rockfall that could breach WPs as they are transported through the openings. Thus, the nonemplacement openings component is ITS. The safety category of the Subsurface Facility is SC (BSC 2005a [DIRS 171668], Attachment A).

The emplacement drifts excavated openings component of the emplacement drift subsystem are ITS and ITWI because they provide the rock properties and emplacement drift layout dimensions for the rockfall analyses used in preclosure safety analyses and postclosure performance confirmation (BSC 2005a [DIRS 171668], Attachment A). The WP emplacement pallet component of the emplacement drift subsystem is ITS and ITWI for providing structural support to protect the WP from damage during surface handling operations and transport to, and into, an emplacement drift. During the preclosure and postclosure periods, the WP emplacement pallet provides support to the WP should a seismic event occur. The safety category of the emplacement drift subsystem is SC (BSC 2005a [DIRS 171668], Attachment A). There is no Category 1 or Category 2 event sequence that requires SSCs in the emplacement drift subsystem to perform prevention or mitigation functions (BSC 2005b [DIRS 171429], Section 7). The 
Seismic Analysis for Preclosure Safety (BSC 2004a [DIRS 171470], Attachment III) has identified potential seismically initiated failures that could lead to undesired consequences.

The postemplacement subsystem and its closure functions during postclosure are ITWI. This subsystem does not include ITS SSCs; it does include ITWI SSCs. The safety category of this subsystem is SC (BSC 2005a [DIRS 171668], Attachment A). There is no Category 1 or Category 2 event sequence that requires SSCs in the postemplacement subsystem to perform preclosure prevention or mitigation functions (BSC 2005b [DIRS 171429], Section 7).

The subsurface development subsystem does not contain spent nuclear fuel (SNF) or HLW. There is no Category 1 or Category 2 event sequence that requires SSCs in this subsystem to perform prevention or mitigation functions (BSC 2005b [DIRS 171429], Section 7). Therefore, this subsystem does not include ITS SSCs or ITWI SSCs or natural or engineered barriers. The safety category of this system is Non-SC (BSC 2005a [DIRS 171668], Attachment A).

The nuclear safety design bases associated with the Subsurface Facility and its subsystems are presented in Table A-I in Appendix A.

\subsubsection{Transportation Cask Receipt/Return Facility}

As established by Categorization of Event Sequences for License Application (BSC 2005b [DIRS 171429], Section 7), Category 2 event sequences could occur in the TCRRF and there are features of the facility that are ITS for prevention or mitigation of event sequences. The Seismic Analysis for Preclosure Safety (BSC 2004a [DIRS 171470], Attachment III) has identified potential seismically initiated failures that could lead to undesired consequences. This facility contains SSCs that are ITS; it does not contain SSCs or natural or engineered barriers that are ITWI. The safety category of this facility is SC (BSC 2005a [DIRS 171668], Attachment A). Table A-I in Appendix A presents the nuclear safety design bases associated with the TCRRF.

\subsubsection{Warehouse and Non-Nuclear Receipt Facility}

As established by Categorization of Event Sequences for License Application (BSC 2005b [DIRS 171429], Section 7), there are no Category 1 or Category 2 event sequences that require SSCs in the WNNRF to perform prevention or mitigation functions. Therefore, this facility consists of no SSCs that are ITS or SSCs or natural or engineered barriers that are ITWI. The safety category of this facility is Non-SC (BSC 2005a [DIRS 171668], Attachment A).

\subsubsection{Waste Process and Infrastructure Systems}

\subsubsection{Cask/MSC/WP Preparation System}

As established by Categorization of Event Sequences for License Application (BSC 2005b [DIRS 171429], Section 7), there are Category 2 event sequences that could occur in this system and there are features of the system that are ITS for prevention or mitigation of event sequences. The Seismic Analysis for Preclosure Safety (BSC 2004a [DIRS 171470], Attachment III) has identified potential seismically initiated failures that could lead to undesired consequences. This system contains SSCs that are ITS; it does not contain SSCs or natural or engineered barriers that are ITWI. The safety category of this system is SC (BSC 2005a [DIRS 171668] Attachment A). 
Table A-II in Appendix A presents the nuclear safety design bases associated with the Cask/MSC/WP Preparation System.

\subsubsection{Cask Receipt and Return System}

As established by Categorization of Event Sequences for License Application (BSC 2005b [DIRS 171429], Section 7), there are Category 2 event sequences that could occur in this system and there are features of the system that are ITS for prevention or mitigation of event sequences. This system consists of SSCs that are ITS; it does not contain SSCs or natural or engineered barriers that are ITWI. The safety category of this system is SC (BSC 2005a [DIRS 171668], Attachment A). Table A-II in Appendix A presents the nuclear safety design bases associated with the Cask Receipt and Return System.

\subsubsection{Communications System}

As established by Categorization of Event Sequences for License Application (BSC 2005b [DIRS 171429], Section 7), there are no Category 1 or Category 2 event sequences that require SSCs in this system to perform prevention or mitigation functions. Therefore, this system consists of no SSCs that are ITS or SSCs or natural or engineered barriers that are ITWI. The safety category of this system is Non-SC (BSC 2005a [DIRS 171668], Attachment A). There are no nuclear safety design bases associated with the Communications System.

\subsubsection{Digital Control and Management Information System}

As established by Categorization of Event Sequences for License Application (BSC 2005b [DIRS 171429], Section 7), there are no Category 1 or Category 2 event sequences that require SSCs in this system to perform prevention or mitigation functions. Therefore, this system consists of no SSCs that are ITS or SSCs or natural or engineered barriers that are ITWI. The safety category of this system is Non-SC (BSC 2005a [DIRS 171668], Attachment A). There are no nuclear safety design bases associated with the Digital Control and Management Information System.

\subsubsection{DOE and Commercial Waste Package System}

As established by Categorization of Event Sequences for License Application (BSC 2005b [DIRS 171429], Section 7), a Category 2 event sequence that requires the WP to perform prevention or mitigation functions could occur (BSC 2005b [DIRS 171429], Section 5.1.3). The Seismic Analysis for Preclosure Safety (BSC 2004a [DIRS 171470], Attachment III) has identified potential seismically initiated failures that could lead to undesired consequences. The WP functions during the preclosure and postclosure periods result in the WP being identified as ITS and ITWI, respectively (BSC 2005a [DIRS 171668], Section 6.3.2.5). The safety category of this system is SC (BSC 2005a [DIRS 171668], Attachment A). Table A-II in Appendix A presents the nuclear safety design bases associated with the DOE and Commercial Waste Package System.

\subsubsection{Electrical Power System}

As established by Categorization of Event Sequences for License Application (BSC 2005b [DIRS 171429], Section 7]), there are Category 1 or Category 2 event sequences that require a function 
or functions of the surface nuclear heating, ventilation, and air-conditioning (HVAC) system for mitigation of Category 1 event sequences (BSC 2005b [DIRS 171429], Section 7). The switchyard, normal power, and emergency power subsystems are required for operation and support of the surface nuclear HVAC system in the DTF and FHF to maintain doses within the performance objectives of 10 CFR 63.111 [DIRS 156605]. The electrical power system supports the availability of the switchyard, normal power, and emergency power to mitigate the consequences of an event sequence. It includes ITS SSCs; it does not include ITWI SSCs or natural or engineered barriers. The safety category of this system is SC (BSC 2005a [DIRS 171668], Attachment A). Table A-II in Appendix A presents the nuclear safety design bases associated with the Electrical Power System.

\subsubsection{Electrical Support System}

As described in Safety Classification of SSCs and Barriers (BSC 2005a [DIRS 171668], Section 6.3.2.7), this system provides electrical support for construction and operation of the surface and subsurface facilities, including ITS functions of the surface nuclear HVAC system. Portions of the cable raceway subsystem that support the availability of electrical power to mitigate the consequences of an event sequence are ITS. SSCs in the remaining portions of the electrical support system do not prevent or mitigate the consequences of a Category 1 or Category 2 event sequence. This system includes ITS SSCs; it does not include ITWI SSCs or natural or engineered barriers. The safety category of this system is SC (BSC 2005a [DIRS 171668], Attachment A). Table A-II in Appendix A presents the nuclear safety design bases associated with the Electrical Support System.

\subsubsection{Emplacement and Retrieval System}

As established by Categorization of Event Sequences for License Application (BSC 2005b [DIRS 171429], Section 7), there are Category 2 event sequences that could occur in this system and there are features of the system that are ITS for prevention or mitigation of event sequences. The Seismic Analysis for Preclosure Safety (BSC 2004a [DIRS 171470], Attachment III) has identified potential seismically initiated failures that could lead to undesired consequences. This system contains SSCs that are ITS; it does not contain SSCs or natural or engineered barriers that are ITWI. The safety category of this system is SC (BSC 2005a [DIRS 171668], Attachment A). Table A-II in Appendix A presents the nuclear safety design bases associated with the Emplacement and Retrieval System.

\subsubsection{Environmental/Meteorological Monitoring System}

As established by Categorization of Event Sequences for License Application (BSC 2005b [DIRS 171429], Section 7), there are no Category 1 or Category 2 event sequences that require SSCs in this system to perform prevention or mitigation functions. Therefore, this system consists of no SSCs that are ITS or SSCs or natural or engineered barriers that are ITWI. The safety category of this system is Non-SC (BSC 2005a [DIRS 171668], Attachment A). There are no nuclear safety design bases associated with the Environmental/Meteorological Monitoring System. 


\subsubsection{Fire Protection System}

As established by Categorization of Event Sequences for License Application (BSC 2005b [DIRS 171429], Section 7), there are no Category 1 or Category 2 event sequences that require SSCs in this system to perform prevention or mitigation functions. Therefore, this system consists of no SSCs that are ITS or SSCs or natural or engineered barriers that are ITWI. The safety category of this system is Non-SC (BSC 2005a [DIRS 171668], Attachment A). There are no nuclear safety design bases associated with the Fire Protection System.

\subsubsection{HVAC Plant Heating and Cooling System}

As established by Categorization of Event Sequences for License Application (BSC 2005b [DIRS 171429], Section 7), there are no Category 1 or Category 2 event sequences that require SSCs in this system to perform prevention or mitigation functions. Therefore, this system consists of no SSCs that are ITS or SSCs or natural or engineered barriers that are ITWI. The safety category of this system is Non-SC (BSC 2005a [DIRS 171668], Attachment A). There are no nuclear safety design bases associated with the HVAC Plant Heating and Cooling System.

\subsubsection{Low-Level Radioactive Waste Generating System}

As established by Categorization of Event Sequences for License Application (BSC 2005b [DIRS 171429] Section 7), there are no Category 1 or Category 2 event sequences that require SSCs in this system to perform prevention or mitigation functions. Therefore, this system consists of no SSCs that are ITS or SSCs or natural or engineered barriers that are ITWI. The safety category of this system is Non-SC (BSC 2005a [DIRS 171668], Attachment A). There are no nuclear safety design bases associated with the Low-Level Radioactive Waste Generating System.

\subsubsection{Low-Level Radioactive Waste Management System}

As established by Categorization of Event Sequences for License Application (BSC 2005b [DIRS 171429], Section 7), there are no Category 1 or Category 2 event sequences that require SSCs in this system to perform prevention or mitigation functions. Therefore, this system consists of no SSCs that are ITS or SSCs or natural or engineered barriers that are ITWI. The safety category of this system is Non-SC (BSC 2005a [DIRS 171668], Attachment A). There are no nuclear safety design bases associated with the Low-Level Radioactive Waste Management System.

\subsubsection{Naval Spent Nuclear Fuel Waste Package System}

As established by Categorization of Event Sequences for License Application (BSC 2005b [DIRS 171429], Section 7), a Category 2 event sequence that requires the WP to perform prevention or mitigation functions could occur (BSC 2005b, Section 5.1.3). The Seismic Analysis for Preclosure Safety (BSC 2004a [DIRS 171470], Attachment III) has identified potential seismically initiated failures that could lead to undesired consequences. The WP functions during the preclosure and postclosure periods result in the WP being identified as ITS and ITWI, respectively (BSC 2005a [DIRS 171668], Section 6.3.2.14). The safety category of this system is SC (BSC 2005a [DIRS 171668], Attachment A). Table A-II in Appendix A presents the nuclear safety design bases associated with the Naval Spent Nuclear Fuel Waste Package System. 


\subsubsection{Non-Nuclear Handling System}

As established by Categorization of Event Sequences for License Application (BSC 2005b [DIRS 171429], Section 7), there are no Category 1 or Category 2 event sequences that require SSCs in this system to perform prevention or mitigation functions. Therefore, this system consists of no SSCs that are ITS or SSCs or natural or engineered barriers that are ITWI. The safety category of this system is Non-SC (BSC 2005a [DIRS 171668], Attachment A). There are no nuclear safety design bases associated with the Non-Nuclear Handling System.

\subsubsection{Non-Radiological Waste Management System}

As established by Categorization of Event Sequences for License Application (BSC 2005b [DIRS 171429], Section 7), there are no Category 1 or Category 2 event sequences that require SSCs in this system to perform prevention or mitigation functions. Therefore, this system consists of no SSCs that are ITS or SSCs or natural or engineered barriers that are ITWI. The safety category of this system is Non-SC (BSC 2005a [DIRS 171668], Attachment A). There are no nuclear safety design bases associated with the Non-Radiological Waste Management System.

\subsubsection{Plant Services System}

As established by Categorization of Event Sequences for License Application (BSC 2005b [DIRS 171429], Section 7), there are no Category 1 or Category 2 event sequences that require SSCs in this system to perform prevention or mitigation functions. Therefore, this system consists of no SSCs that are ITS or SSCs or natural or engineered barriers that are ITWI. The safety category of this system is Non-SC (BSC 2005a [DIRS 171668], Attachment A). There are no nuclear safety design bases associated with the Plant Services System.

\subsubsection{Radiation/Radiological Monitoring System}

As established by Categorization of Event Sequences for License Application (BSC 2005b [DIRS 171429], Section 7), there are no Category 1 or Category 2 event sequences that require SSCs in this system to perform prevention or mitigation functions. Therefore, this system consists of no SSCs that are ITS or SSCs or natural or engineered barriers that are ITWI. The safety category of this system is Non-SC (BSC 2005a [DIRS 171668], Attachment A). There are no nuclear safety design bases associated with the Radiation/Radiological Monitoring System.

\subsubsection{Remediation System}

As established by Categorization of Event Sequences for License Application (BSC 2005b [DIRS 171429], Section 7), a Category 2 event sequence could occur in this system and there are features of the system that are ITS for prevention or mitigation of event sequences. The Seismic Analysis for Preclosure Safety (BSC 2004a [DIRS 171470], Attachment III) has identified potential seismically initiated failures that could lead to undesired consequences. This system contains SSCs that are ITS; it does not contain SSCs or natural or engineered barriers that are ITWI. The safety category of this system is SC (BSC 2005a [DIRS 171668], Attachment A). Table A-II in Appendix A presents the nuclear safety design bases associated with the Remediation System. 


\subsubsection{Safeguards and Security System}

As established by Categorization of Event Sequences for License Application (BSC 2005b [DIRS 171429], Section 7), there are no Category 1 or Category 2 event sequences that require SSCs in this system to perform prevention or mitigation functions. Therefore, this system consists of no SSCs that are ITS or SSCs or natural or engineered barriers that are ITWI. The safety category of this system is Non-SC (BSC 2005a [DIRS 171668], Attachment A). There are no nuclear safety design bases associated with the Safeguards and Security System.

\subsubsection{SNF Aging System}

As established by Categorization of Event Sequences for License Application (BSC 2005b [DIRS 171429], Section 7), a Category 2 event sequence could occur in this system and there are features of the system that are ITS for prevention or mitigation of event sequences. The Seismic Analysis for Preclosure Safety (BSC 2004a [DIRS 171470], Attachment III) has identified potential seismically initiated failures that could lead to undesired consequences. This system contains SSCs that are ITS; it does not contain SSCs or natural or engineered barriers that are ITWI. The safety category of this system is SC (BSC 2005a [DIRS 171668], Attachment A). Table A-II in Appendix A presents the nuclear safety design bases associated with the SNF Aging System.

\subsubsection{SNF/HLW Transfer System}

As established by Categorization of Event Sequences for License Application (BSC 2005b [DIRS 171429], Section 7) and Preclosure Consequence Analyses for License Application (BSC 2005c [DIRS 171607], Section 7), there are Category 1 and Category 2 event sequences that require SSCs in this system to perform prevention or mitigation functions. As established by Preclosure Consequence Analyses for License Application (BSC 2005c [DIRS 171607], Section 7), the worker radiation doses and offsite radiation doses for Category 1 and Category 2 event sequences meet the 10 CFR Part 63 [DIRS 156605] performance objectives. This system contains SSCs that are ITS; it does not contain SSCs or natural or engineered barriers that are ITWI. The safety category of this system is SC (BSC 2005a [DIRS 171668], Attachment A). Table A-II in Appendix A presents the nuclear safety design bases associated with the SNF/HLW Transfer System.

\subsubsection{Subsurface Ventilation System}

As established by Categorization of Event Sequences for License Application (BSC 2005b [DIRS 171429], Section 7), there are no Category 1 or Category 2 event sequences that require SSCs in this system to perform prevention or mitigation functions. Therefore, this system consists of no SSCs that are ITS or SSCs or natural or engineered barriers that are ITWI. The safety category of this system is Non-SC (BSC 2005a [DIRS 171668], Attachment A). There are no nuclear safety design bases associated with the Subsurface Ventilation System.

\subsubsection{Surface Industrial HVAC System}

As established by Categorization of Event Sequences for License Application (BSC 2005b [DIRS 171429], Section 5.1.2.4) there are Category 1 or Category 2 event sequences that require SSCs 
in this system to perform prevention or mitigation functions. Therefore, this system includes SSCs that are ITS; it does not include ITWI SSCs or natural or engineered barriers. The safety category of this system is SC (BSC 2005a [DIRS 171668], Attachment A). Table A-II in Appendix A presents the nuclear safety design bases associated with the Surface Industrial HVAC System.

\subsubsection{Surface Nuclear HVAC System}

As established by Categorization of Event Sequences for License Application (BSC 2005b [DIRS 171429], Section 7) and the Preclosure Consequence Analysis for License Application (BSC 2005c [DIRS 171607]), there are Category 1 event sequences that require SSCs in this system to perform prevention or mitigation functions. The Seismic Analysis for Preclosure Safety (BSC 2004a [DIRS 171470], Attachment III) has identified potential seismically initiated failures that could lead to undesired consequences. This system contains SSCs that are ITS; it does not contain SSCs or natural or engineered barriers that are ITWI. The safety category of this system is SC (BSC 2005a [DIRS 171668], Attachment A). Table A-II in Appendix A presents the nuclear safety design bases associated with the Surface Nuclear HVAC System.

\subsubsection{Waste Package Closure System}

As established by Categorization of Event Sequences for License Application (BSC 2005b [DIRS 171429], Section 7), there are no Category 1 or Category 2 event sequences that require SSCs in this system to perform prevention or mitigation functions. Therefore, this system consists of no SSCs that are ITS or SSCs or natural or engineered barriers that are ITWI. The safety category of this system is Non-SC (BSC 2005a [DIRS 171668], Attachment A). There are no nuclear safety design bases associated with the Waste Package Closure System.

\subsection{OTHER ITEMS IMPORTANT TO SAFETY}

The transportation casks, standardized U.S. Department of Energy (DOE) SNF disposable canisters, DOE HLW canisters, DOE multicanister overpacks (MCOs), the naval SNF canisters, and the dual-purpose canisters (DPCs) are ITS, but are not a part of the repository architecture (Lucas 2004 [DIRS 170073]). In the Categorization of Event Sequences for License Application analysis (BSC 2005b [DIRS 171429], Section 7) it was established that a breach of a transportation cask with impact limiters installed is a Beyond Category 2 event sequence based on the 10 CFR 71.55 [DIRS 104091] and 10 CFR 71.73 [DIRS 104091] design requirements for the transportation casks (BSC 2005b [DIRS 171429], Section 7). A breach of a DOE MCO or a standardized DOE SNF canister is a Beyond Category 2 event sequence based on the acceptance requirements of the Waste Acceptance System Requirements Document (DOE 2002 [DIRS 158873], Section 4.3.7). A breach of the DOE HLW canister, naval SNF canister, or DPC as a result of a credible fire is a Beyond Category 2 event sequence (BSC 2004c [DIRS 171488], Section 5).

To ensure that transportation casks with impact limiters installed and that standardized DOE SNF canisters are capable of withstanding drops within the design basis without breach, they have been designated as ITS and classified as SC (BSC 2005a [DIRS 171668], Attachment A). Table A-II in Appendix A presents the nuclear safety design bases associated with transportation 
casks, DOE HLW canisters, DOE MCOs, naval SNF canisters, standardized DOE SNF canisters, and DPCs.

\section{CONCLUSIONS}

The 10 CFR 63.2 design bases (nuclear safety design bases) selected in this report using the methodology presented in Section 6.1 are listed in Appendix A. These nuclear safety design bases are used as input to the design of the repository. These output results are reasonable compared to the input and are suitable for their intended use. As the design of the repository proceeds and further event sequences and consequence analyses of hazards are performed, this report will be reviewed for impact and revised as necessary.

\section{REFERENCES}

\subsection{DOCUMENTS CITED}

[DIRS 171470]

BSC (Bechtel SAIC Company) 2004a. Seismic Analysis for Preclosure Safety. 000-00CMGR0-00700-000-00B. Las Vegas, Nevada: Bechtel SAIC Company. ACC:

ENG.20041216.0031.

[DIRS 167266]

BSC 2004b. Monitored Geologic Repository External Events Hazards Screening Analysis. 00000C-MGR0-00500-000-00A. Las Vegas, Nevada: Bechtel SAIC Company. ACC:

ENG.20040712.0004.

[DIRS 171488]

BSC 2004c. Fire-Induced Event Sequence Analysis. 000-00C-MGR0-01300-000-00B. Las

Vegas, Nevada: Bechtel SAIC Company. ACC: ENG.20041208.0001.

[DIRS 171471]

BSC 2004d. Extreme Wind/Tornado/Tornado Missile Hazard Analysis. 000-00C-WHS0-

00100-000-00B. Las Vegas, Nevada: Bechtel SAIC Company. ACC: ENG.20041105.0001.

[DIRS 167232]

BSC 2004e. Dry Transfer Facility Description Document. 110-3YD-CD00-00100-000-000.

Las Vegas, Nevada: Bechtel SAIC Company. ACC: ENG.20040712.0002.

[DIRS 171490]

BSC 2004f. Reliability Analysis of the Electrical Power Distribution System to Selected Portions of the Nuclear HVAC System. 100-PSA-EE00-00100-000-00A. Las Vegas, Nevada:

Bechtel SAIC Company. ACC: ENG.20041216.0029.

[DIRS 171599]

BSC 2004g. Project Design Criteria Document. 000-3DR-MGR0-00100-000-003. Las Vegas, Nevada: Bechtel SAIC Company. ACC: ENG.20041124.0001. 
[DIRS 171668]

BSC 2005a. Safety Classification of SSCs and Barriers. 000-00C-MGR0-01000-000-001. Las Vegas, Nevada: Bechtel SAIC Company. ENG.20050215.0007.

[DIRS 171429]

BSC 2005b. Categorization of Event Sequences for License Application. 000-00C-MGR000800-000-00B. Las Vegas, Nevada: Bechtel SAIC Company. ACC: MOL.20050301.0445.

[DIRS 171607]

BSC 2005c. Preclosure Consequence Analyses for License Application. 000-00C-MGR000900-000-00B. Las Vegas, Nevada: Bechtel SAIC Company. ACC: ENG.20050112.0003.

[DIRS 171786]

BSC 2005d. Frequency Analysis of Aircraft Hazards for License Application. 000-00C-WHS000200-000-00B. Las Vegas, Nevada: Bechtel SAIC Company. ACC: ENG.20050214.0009.

[DIRS 171793]

Cogema 2004. SNF Aging System Safety Study. COGEMA-C0115-RP-04-005, Rev. 1. Las Vegas, Nevada: Cogema. ACC: ENG.20040917.0002.

[DIRS 158873]

DOE (U.S. Department of Energy) 2002. Waste Acceptance System Requirements Document. DOE/RW-0351, Rev. 4. Washington, D.C.: U.S. Department of Energy, Office of Civilian Radioactive Waste Management. ACC: MOL.20020326.0056.

[DIRS 171539]

DOE 2004. Quality Assurance Requirements and Description. DOE/RW-0333P, Rev. 16. Washington, D.C.: U.S. Department of Energy, Office of Civilian Radioactive Waste Management. ACC: DOC.20040907.0002.

[DIRS 170073]

Lucas, L. 2004. "Facility, Equipment and System Names for Use in the SAR." Interoffice memorandum from L. Lucas (BSC) to M.R. Bryan, June 24, 2004, 0521041674. ACC:

MOL.20040625.0028.

\subsection{CODES, STANDARDS, AND REGULATIONS}

[DIRS 156605]

10 CFR 63. Energy: Disposal of High-Level Radioactive Wastes in a Geologic Repository at Yucca Mountain, Nevada. Readily available.

[DIRS 104091]

10 CFR 71. Energy: Packaging and Transportation of Radioactive Material. Readily available. 


\subsection{PROCEDURES}

AP-3.13Q, Rev. 3, ICN 3. Design Control. ACC: DOC.20040202.0006.

LP-3.11Q-BSC, Rev. 0, ICN 2. Technical Reports. ACC: DOC.20050215.0009.

LP-3.15Q-BSC, Rev. 0, ICN 0. Managing Technical Product Inputs. ACC:

DOC.20050113.0002.

LP-SI.11Q-BSC, Rev. 0, ICN 1. Software Management. ACC: DOC.20040015.0008. 
INTENTIONALLY LEFT BLANK 
APPENDIX A

Table A-I. Nuclear Safety Design Bases of Facilities

\begin{tabular}{|c|c|c|c|c|}
\hline $\begin{array}{l}\text { Facility, System, or } \\
\text { Subsystem }\end{array}$ & $\begin{array}{l}\text { Component or } \\
\text { Function }\end{array}$ & $\begin{array}{l}\text { ITS or } \\
\text { ITWI }\end{array}$ & $\begin{array}{l}\text { Safety } \\
\text { Category }\end{array}$ & Nuclear Safety Design Bases \\
\hline \multicolumn{5}{|c|}{ Balance of Plant Facilities } \\
\hline $\begin{array}{l}\text { Administration, } \\
\text { Security, Utility, } \\
\text { Emergency } \\
\text { Response, Offsite, } \\
\text { Materials and } \\
\text { Consumables, Fire } \\
\text { Water, Maintenance } \\
\text { and Repair, } \\
\text { Generator, } \\
\text { Switchgear, } \\
\text { Construction } \\
\text { Support, Central } \\
\text { Control Center, and } \\
\text { Transportation } \\
\text { Facilities }\end{array}$ & Structure & N/A & Non-SC & $\begin{array}{l}\text { Not applicable. None of the SSC functions associated with these facilities are creditec } \\
\text { for the prevention or mitigation of an event sequence. }\end{array}$ \\
\hline \multicolumn{5}{|c|}{ Canister Handling Facility } \\
\hline $\mathrm{CHF}$ & Structure & ITS & SC & $\begin{array}{l}\text { - The structure shall: } \\
\text { (1) be designed for the loads associated with a design basis extreme wind speed. } \\
\text { (BSC 2004g Section 6.1.1.2 and BSC 2004d Section 9) } \\
\text { be designed for the loads associated with a design basis tornado maximum } \\
\text { wind speed with a corresponding pressure drop and rate of pressure drop. } \\
\text { (BSC 2004g Section 4.2.2.3.7 and BSC 2004d Section 9) } \\
\text { (3) not allow the penetration of Spectrum II tornado missiles, except for the } \\
\text { entrance and exit vestibules and the steel structures on top of the building. } \\
\text { (BSC 2004d Sections 6.4.4.1.1 and 9) } \\
\text { - The roof of the structure shall be designed for the loads associated with the } \\
\text { maximum observed hourly precipitation event (with a 100-year return period). (BSC } \\
\text { 2004g Section 6.1.1.1.2 and BSC 2005b Section 4.3.2) }\end{array}$ \\
\hline
\end{tabular}


Table A-I. Nuclear Safety Design Bases of Facilities

\begin{tabular}{|c|c|c|c|c|}
\hline $\begin{array}{l}\text { Facility, System, or } \\
\text { Subsystem }\end{array}$ & $\begin{array}{l}\text { Component or } \\
\text { Function }\end{array}$ & $\begin{array}{l}\text { ITS or } \\
\text { ITWI }\end{array}$ & $\begin{array}{l}\text { Safety } \\
\text { Category }\end{array}$ & Nuclear Safety Design Bases \\
\hline CHF (continued) & Structure (continued) & ITS & SC & 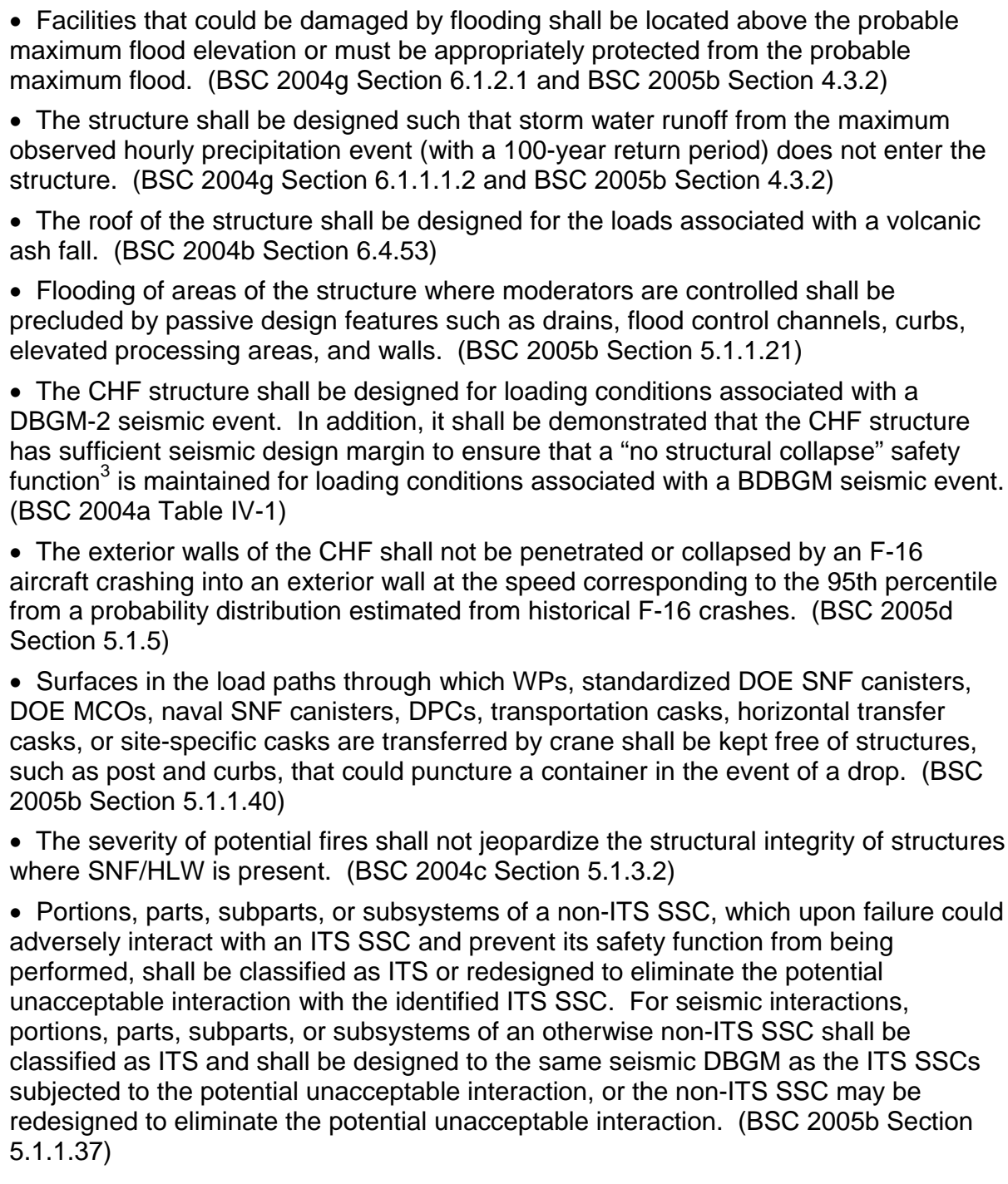 \\
\hline
\end{tabular}


Table A-I. Nuclear Safety Design Bases of Facilities

\begin{tabular}{|c|c|c|c|c|}
\hline $\begin{array}{l}\text { Facility, System, or } \\
\text { Subsystem }\end{array}$ & $\begin{array}{l}\text { Component or } \\
\text { Function }\end{array}$ & $\begin{array}{l}\text { ITS or } \\
\text { ITWI }\end{array}$ & $\begin{array}{l}\text { Safety } \\
\text { Category }\end{array}$ & Nuclear Safety Design Bases \\
\hline \multirow[t]{2}{*}{ CHF (continued) } & $\begin{array}{l}\text { Rails for Trolleys, WP } \\
\text { Transporters, and } \\
\text { SRTCs }\end{array}$ & ITS & SC & $\begin{array}{l}\text { - The rails and rail anchorages within the structure shall be designed for loading } \\
\text { conditions associated with a DBGM-2 seismic event. In addition, it shall be } \\
\text { demonstrated that the rails and rail anchorages have sufficient seismic design margin } \\
\text { to ensure that a "no derailment" safety function }{ }^{3} \text { is maintained for loading conditions } \\
\text { associated with a BDBGM seismic event. (BSC 2004a Table IV-1) }\end{array}$ \\
\hline & $\begin{array}{l}\text { Permanent Shielding } \\
\text { (including shield doors, } \\
\text { shield view ports, and } \\
\text { viewing windows) }\end{array}$ & ITS & SC & $\begin{array}{l}\text { - The CHF permanent shielding (including shield doors, shield view ports, and viewing } \\
\text { windows) shall be designed for loading conditions associated with a DBGM-1 seismic } \\
\text { event to demonstrate sufficient seismic design margin to ensure that a "shielding } \\
\text { integrity remains intact" safety function }{ }^{3} \text { is maintained. (BSC 2004a Table IV-1) } \\
\text { - Closure of airlock doors, shield doors, or other applicable doors on a trolley, SRTC, } \\
\text { WP transporter, or other conveyance shall not cause a tipover of the conveyance or } \\
\text { cause the conveyance to drop its load. (BSC } 2005 \text { bection 5.1.1.13) } \\
\text { - Radiation exposure to workers due to inadvertent actuation of doors or pit protective } \\
\text { covers shall be precluded such that this is not a Category } 1 \text { event. (BSC 2005b } \\
\text { Section 5.1.1.57) }\end{array}$ \\
\hline \multicolumn{5}{|c|}{ Dry Transfer Facility } \\
\hline DTF & Structure & ITS & SC & $\begin{array}{l}\text { - The structure shall: } \\
\text { (1) be designed for the loads associated with a design basis extreme wind speed. } \\
\text { (BSC 2004g Section 6.1.1.2 and BSC 2004d Section 9) } \\
\text { (2) be designed for the loads associated with a design basis tornado maximum } \\
\text { wind speed with a corresponding pressure drop and rate of pressure drop. } \\
\text { (BSC 2004g Section 4.2.2.3.7 and BSC 2004d Section 9) } \\
\text { (3) not allow the penetration of Spectrum II tornado missiles, except for the } \\
\text { entrance and exit vestibules and the steel structures on the DTF roof. (BSC } \\
2004 \mathrm{~d} \text { Sections 6.4.4.1.1 and 9) } \\
\text { - The roof of the structure shall be designed for the loads associated with the } \\
\text { maximum observed hourly precipitation event (with a 100-year return period). (BSC } \\
\text { 2004g Section 6.1.1.1.2 and BSC 2005b Section 4.3.2) } \\
\text { - Facilities that could be damaged by flooding shall be located above the probable } \\
\text { maximum flood elevation or must be appropriately protected from the probable } \\
\text { maximum flood. (BSC 2004g Section 6.1.2.1 and BSC 2005b Section 4.3.2) }\end{array}$ \\
\hline
\end{tabular}


Table A-I. Nuclear Safety Design Bases of Facilities

\begin{tabular}{|c|c|c|c|c|}
\hline $\begin{array}{l}\text { Facility, System, or } \\
\text { Subsystem }\end{array}$ & $\begin{array}{l}\text { Component or } \\
\text { Function }\end{array}$ & $\begin{array}{l}\text { ITS or } \\
\text { ITWI }\end{array}$ & $\begin{array}{l}\text { Safety } \\
\text { Category }\end{array}$ & Nuclear Safety Design Bases \\
\hline DTF (continued) & Structure (continued) & ITS & SC & 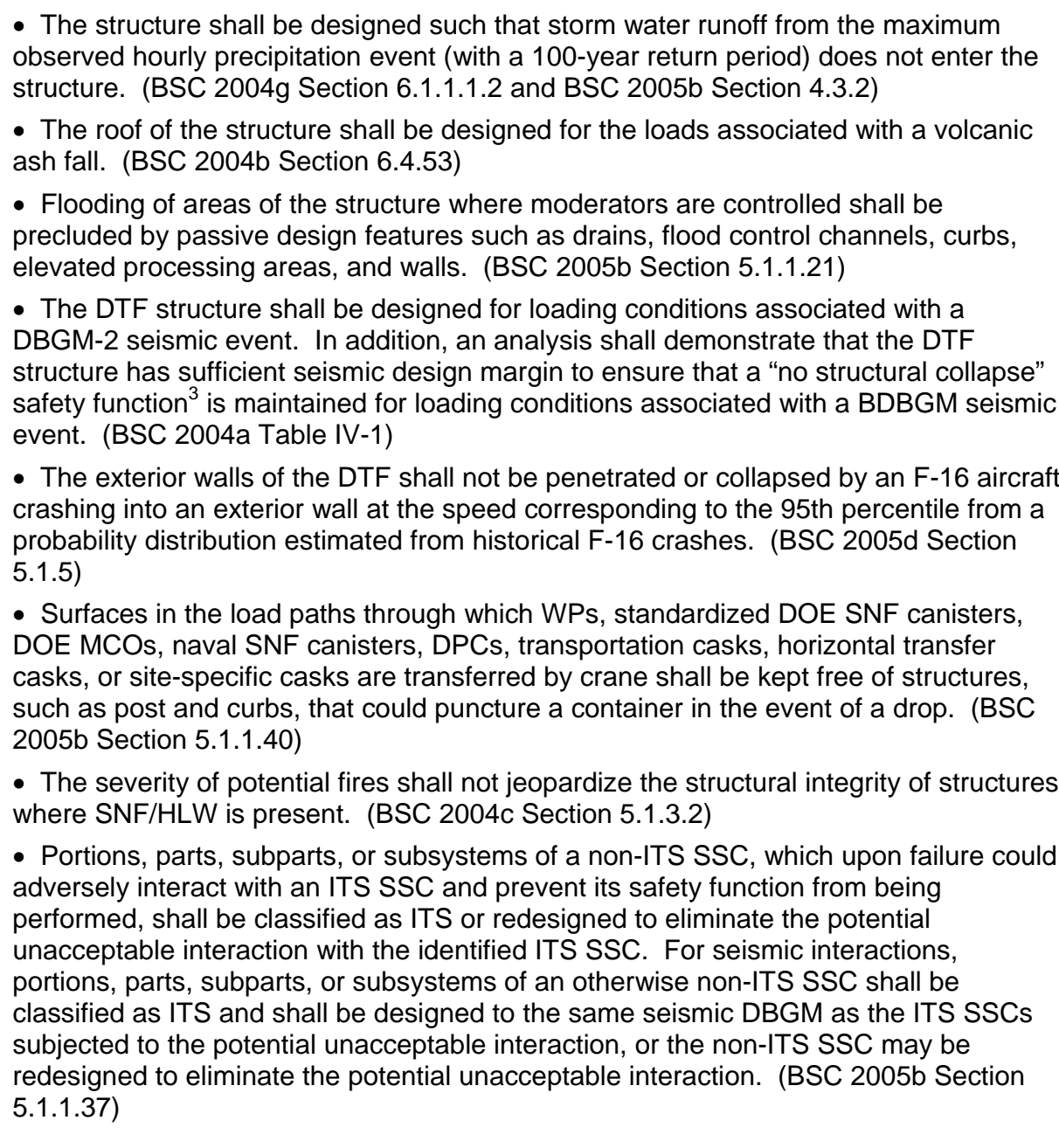 \\
\hline
\end{tabular}


Table A-I. Nuclear Safety Design Bases of Facilities

\begin{tabular}{|c|c|c|c|c|}
\hline $\begin{array}{l}\text { Facility, System, or } \\
\text { Subsystem }\end{array}$ & $\begin{array}{l}\text { Component or } \\
\text { Function }\end{array}$ & $\begin{array}{l}\text { ITS or } \\
\text { ITWI }\end{array}$ & $\begin{array}{l}\text { Safety } \\
\text { Category }\end{array}$ & Nuclear Safety Design Bases \\
\hline \multirow[t]{3}{*}{ DTF (continued) } & Remediation Pool & ITS & SC & $\begin{array}{l}\text { - The remediation pool structure shall be designed for loading conditions associated } \\
\text { with a DBGM-2 seismic event. In addition, an analysis shall demonstrate that the } \\
\text { remediation pool structure has sufficient seismic design margin to ensure that a "no } \\
\text { failure" safety function }{ }^{3} \text { is maintained for loading conditions associated with a BDBGM } \\
\text { seismic event. (BSC } 2004 a \text { Table IV-1) } \\
\text { - The pool and pool area in the remediation system shall ensure that any lost water } \\
\text { can be replaced with make-up water until the cause of the loss is corrected or waste } \\
\text { forms are removed from the pool. The minimum available rate of make-up water shall } \\
\text { be sufficient to replenish evaporation and the maximum potential leakage in the event } \\
\text { of the failure of the recirculating cooling system over the minimum time period required } \\
\text { to remove waste forms from the pool. The rate shall also be sufficient to prevent the } \\
\text { uncovering of the waste forms over this same period. (BSC 2005b Section 5.1.2.5) }\end{array}$ \\
\hline & $\begin{array}{l}\text { Rail Systems for } \\
\text { Trolleys, WP } \\
\text { Transporters, and } \\
\text { SRTCs }\end{array}$ & ITS & SC & $\begin{array}{l}\text { - The rails and rail anchorages within the structure shall be designed for loading } \\
\text { conditions associated with a DBGM-2 seismic event. In addition, it shall be } \\
\text { demonstrated that the rails and rail anchorages have sufficient seismic design margin } \\
\text { to ensure that a "no derailment" safety function }{ }^{3} \text { is maintained for loading conditions } \\
\text { associated with a BDBGM seismic event. (BSC 2004a Table IV-1) }\end{array}$ \\
\hline & $\begin{array}{l}\text { Permanent Shielding } \\
\text { (including shield doors, } \\
\text { shield view ports, and } \\
\text { viewing windows) }\end{array}$ & ITS & SC & $\begin{array}{l}\text { - The DTF permanent shielding (including shield doors, shield view ports, and viewing } \\
\text { windows) shall be designed for loading conditions associated with a DBGM-1 seismic } \\
\text { event to demonstrate sufficient seismic design margin to ensure that a "shielding } \\
\text { integrity remains intact" safety function }{ }^{3} \text { is maintained. (BSC 2004a Table IV-1) } \\
\text { - Closure of airlock doors, shield doors, or other applicable doors on a trolley, SRTC, } \\
\text { site-specific cask transporter, WP transporter, other conveyance, or transportation } \\
\text { cask or site-specific cask suspended from an overhead crane shall not cause a tipover } \\
\text { of the conveyance or cause the conveyance or crane to drop its load. (BSC 2005b } \\
\text { Section 5.1.1.13) } \\
\text { - Radiation exposure to workers due to inadvertent actuation of doors shall be } \\
\text { precluded such that this is not a Category } 1 \text { event. (BSC 2005b Section 5.1.1.57) }\end{array}$ \\
\hline \multicolumn{5}{|c|}{ Fuel Handling Facility } \\
\hline $\mathrm{FHF}$ & Structure & ITS & SC & $\begin{array}{l}\text { - The structure shall: } \\
\text { (1) be designed for the loads associated with a design basis extreme wind speed. } \\
\text { (BSC 2004g Section 6.1.1.2 and BSC 2004d Section 9) }\end{array}$ \\
\hline
\end{tabular}


Table A-I. Nuclear Safety Design Bases of Facilities

\begin{tabular}{|c|c|c|c|c|}
\hline $\begin{array}{l}\text { Facility, System, or } \\
\text { Subsystem }\end{array}$ & $\begin{array}{l}\text { Component or } \\
\text { Function }\end{array}$ & $\begin{array}{l}\text { ITS or } \\
\text { ITWI }\end{array}$ & $\begin{array}{l}\text { Safety } \\
\text { Category }\end{array}$ & Nuclear Safety Design Bases \\
\hline FHF (continued) & Structure (continued) & ITS & SC & 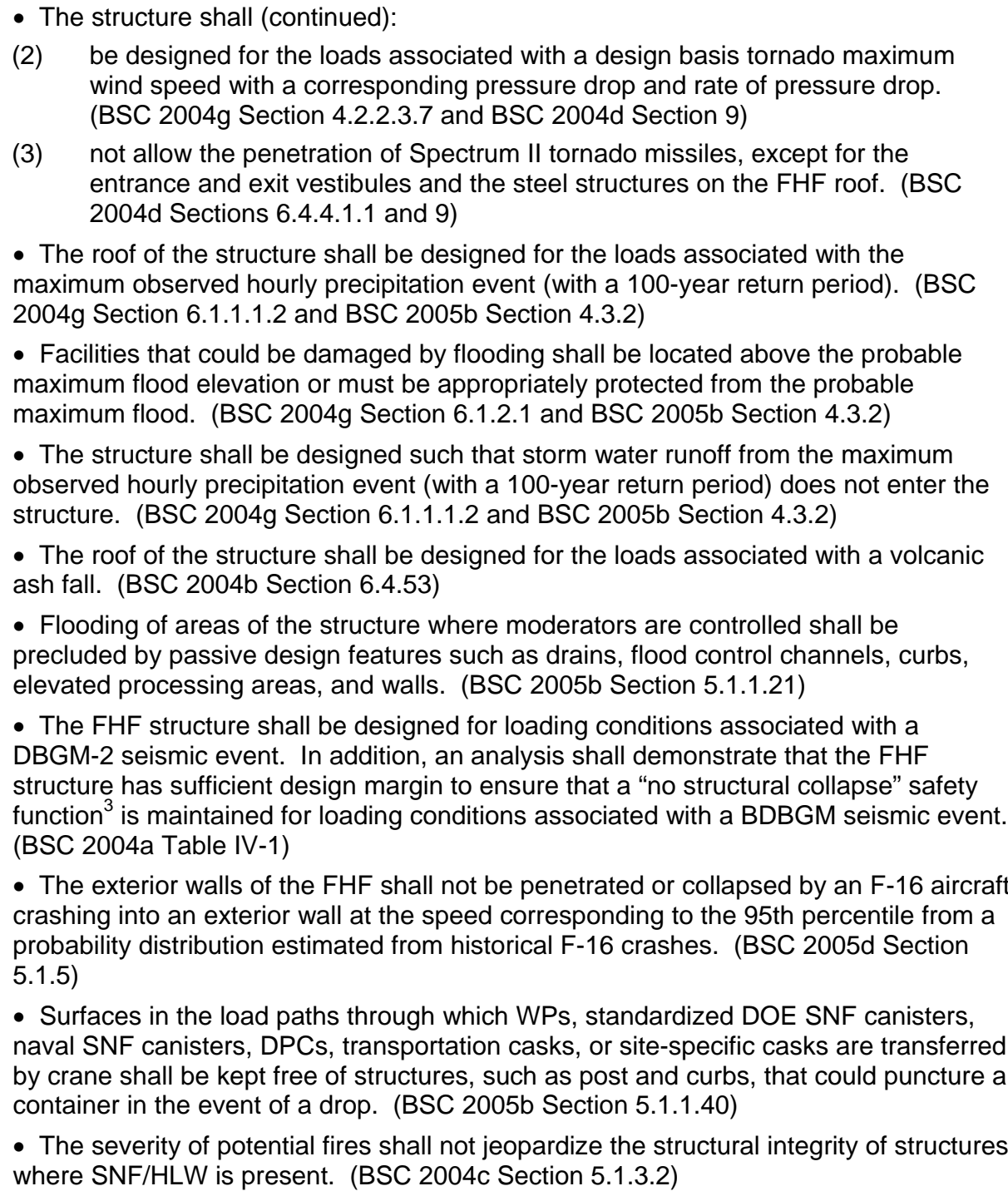 \\
\hline
\end{tabular}


Table A-I. Nuclear Safety Design Bases of Facilities

\begin{tabular}{|c|c|c|c|c|}
\hline $\begin{array}{l}\text { Facility, System, or } \\
\text { Subsystem }\end{array}$ & $\begin{array}{l}\text { Component or } \\
\text { Function }\end{array}$ & $\begin{array}{l}\text { ITS or } \\
\text { ITWI }\end{array}$ & $\begin{array}{l}\text { Safety } \\
\text { Category }\end{array}$ & Nuclear Safety Design Bases \\
\hline \multirow[t]{3}{*}{ FHF (continued) } & Structure (continued) & ITS & SC & $\begin{array}{l}\text { - Portions, parts, subparts, or subsystems of a non-ITS SSC, which upon failure could } \\
\text { adversely interact with an ITS SSC and prevent its safety function from being } \\
\text { performed, shall be classified as ITS or redesigned to eliminate the potential } \\
\text { unacceptable interaction with the identified ITS SSC. For seismic interactions, } \\
\text { portions, parts, subparts, or subsystems of an otherwise non-ITS SSC shall be } \\
\text { classified as ITS and shall be designed to the same seismic DBGM as the ITS SSCs } \\
\text { subjected to the potential unacceptable interaction, or the non-ITS SSC may be } \\
\text { redesigned to eliminate the potential unacceptable interaction. (BSC 2005b Section } \\
5.1 .1 .37 \text { ) }\end{array}$ \\
\hline & $\begin{array}{l}\text { Rail Systems for } \\
\text { Trolleys and the WP } \\
\text { Transporter }\end{array}$ & ITS & SC & $\begin{array}{l}\text { - The rails and rail anchorages within the structure shall be designed for loading } \\
\text { conditions associated with a DBGM-2 seismic event. In addition, it shall be } \\
\text { demonstrated that the rails and rail anchorages have sufficient seismic design margin } \\
\text { to ensure that a "no derailment" safety function }{ }^{3} \text { is maintained for loading conditions } \\
\text { associated with a BDBGM seismic event. (BSC 2004a Table IV-1) }\end{array}$ \\
\hline & $\begin{array}{l}\text { Permanent Shielding } \\
\text { (including shield doors, } \\
\text { shield view ports, and } \\
\text { viewing windows) }\end{array}$ & ITS & SC & $\begin{array}{l}\text { - Closure of airlock doors, shield doors, or other applicable doors on a trolley, SRTC, } \\
\text { WP transporter, or other conveyance, or a site-specific cask suspended from the } \\
\text { vestibule gantry crane, shall not cause a tipover of the conveyance or cause the } \\
\text { conveyance or crane to drop its load. (BSC 2005b Section 5.1.1.13) } \\
\text { - The FHF permanent shielding (including shield doors, shield view ports, and viewing } \\
\text { windows) shall be designed for loading conditions associated with a DBGM-1 seismic } \\
\text { event to demonstrate sufficient seismic design margin to ensure that a "shielding } \\
\text { integrity remains intact" safety function }{ }^{3} \text { is maintained. (BSC 2004a Table IV-1) } \\
\text { - Radiation exposure to workers due to inadvertent actuation of doors shall be } \\
\text { precluded such that this is not a Category } 1 \text { event. (BSC 2005b Section 5.1.1.57) }\end{array}$ \\
\hline \multicolumn{5}{|c|}{ Subsurface Facility } \\
\hline Subsurface Facility & Rails & N/A & Non-SC & $\begin{array}{l}\text { Not Applicable. None of the SSC functions associated with this subsystem are } \\
\text { credited for the prevention or mitigation of an event sequence. }\end{array}$ \\
\hline
\end{tabular}


Table A-I. Nuclear Safety Design Bases of Facilities

\begin{tabular}{|c|c|c|c|c|}
\hline $\begin{array}{l}\text { Facility, System, or } \\
\text { Subsystem }\end{array}$ & $\begin{array}{l}\text { Component or } \\
\text { Function }\end{array}$ & $\begin{array}{l}\text { ITS or } \\
\text { ITWI }\end{array}$ & $\begin{array}{l}\text { Safety } \\
\text { Category }\end{array}$ & Nuclear Safety Design Bases \\
\hline \multirow[t]{3}{*}{$\begin{array}{l}\text { Subsurface Facility } \\
\text { (continued) }\end{array}$} & $\begin{array}{l}\text { Size and Layout of } \\
\text { Drifts }\end{array}$ & $\begin{array}{l}\text { ITS } \\
\text { ITWI }\end{array}$ & SC & $\begin{array}{l}\text { - The design of the subsurface facility shall ensure that the size and layout of the } \\
\text { emplacement drifts are consistent with the drift and rockfall modeling, including the } \\
\text { evaluation of the characteristics of the credible bounding rockfalls. (BSC 2005b } \\
\text { Section 6.3.6.1.20) } \\
\text { - Portions, parts, subparts, or subsystems of a non-ITS SSC, which upon failure could } \\
\text { adversely interact with an ITS SSC and prevent its safety function from being } \\
\text { performed, shall be classified as ITS or redesigned to eliminate the potential } \\
\text { unacceptable interaction with the identified ITS SSC. For seismic interactions, } \\
\text { portions, parts, subparts, or subsystems of an otherwise non-ITS SSC shall be } \\
\text { classified as ITS and shall be designed to the same seismic DBGM as the ITS SSCs } \\
\text { subjected to the potential unacceptable interaction, or the non-ITS SSC may be } \\
\text { redesigned to eliminate the potential unacceptable interaction. (BSC 2005b Section } \\
\text { 5.1.1.37) }\end{array}$ \\
\hline & $\begin{array}{l}\text { Nonemplacement } \\
\text { Openings }\end{array}$ & ITS & SC & $\begin{array}{l}\text { - The design shall ensure size and layout of nonemplacement openings are } \\
\text { consistent with drift and rockfall modeling. (BSC 2005b Section 6.3.6.1.20) } \\
\text { - The ramp, portals, shafts, and shaft collar areas shall be protected from water inflow } \\
\text { as a result of the probable maximum flood. (BSC 2005b Section 4.3.2) } \\
\text { - Portions, parts, subparts, or subsystems of a non-ITS SSC, which upon failure could } \\
\text { adversely interact with an ITS SSC and prevent its safety function from being } \\
\text { performed, shall be classified as ITS or redesigned to eliminate the potential } \\
\text { unacceptable interaction with the identified ITS SSC. For seismic interactions, } \\
\text { portions, parts, subparts, or subsystems of an otherwise non-ITS SSC shall be } \\
\text { classified as ITS and shall be designed to the same seismic DBGM as the ITS SSCs } \\
\text { subjected to the potential unacceptable interaction, or the non-ITS SSC may be } \\
\text { redesigned to eliminate the potential unacceptable interaction. (BSC 2005b Section } \\
\text { 5.1.1.37) }\end{array}$ \\
\hline & $\begin{array}{l}\text { Ground Support for } \\
\text { Nonemplacement } \\
\text { Openings }\end{array}$ & N/A & Non-SC & $\begin{array}{l}\text { Not Applicable. None of the SSC functions associated with this subsystem are } \\
\text { credited for the prevention or mitigation of a preclosure event sequence. }\end{array}$ \\
\hline $\begin{array}{l}\text { Subsurface Facility } \\
\text { Emplacement Drift }\end{array}$ & $\begin{array}{l}\text { Emplacement Drift } \\
\text { Excavated Opening }\end{array}$ & $\begin{array}{l}\text { ITS } \\
\text { ITWI }\end{array}$ & $\mathrm{SC}$ & $\begin{array}{l}\text { - The design shall ensure size and layout of emplacement drifts are consistent with } \\
\text { drift and rockfall modeling. (BSC 2005b Section 6.3.6.1.20) }\end{array}$ \\
\hline
\end{tabular}


Table A-I. Nuclear Safety Design Bases of Facilities

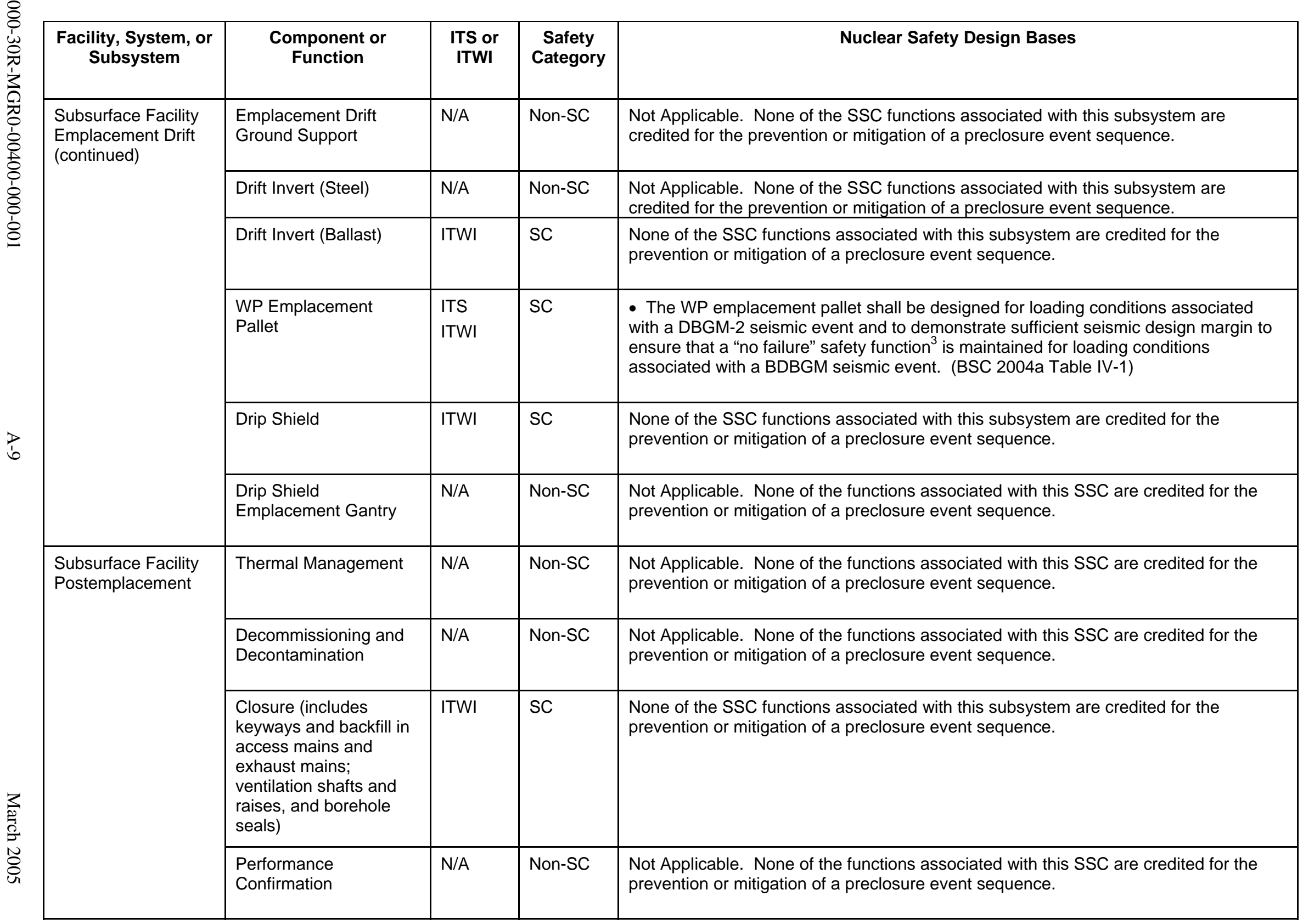


Table A-I. Nuclear Safety Design Bases of Facilities

\begin{tabular}{|c|c|c|c|c|}
\hline $\begin{array}{l}\text { Facility, System, or } \\
\text { Subsystem }\end{array}$ & $\begin{array}{l}\text { Component or } \\
\text { Function }\end{array}$ & $\begin{array}{l}\text { ITS or } \\
\text { ITWI }\end{array}$ & $\begin{array}{l}\text { Safety } \\
\text { Category }\end{array}$ & Nuclear Safety Design Bases \\
\hline $\begin{array}{l}\text { Subsurface Facility } \\
\text { Subsurface } \\
\text { Development }\end{array}$ & Excavation & N/A & Non-SC & $\begin{array}{l}\text { Not Applicable. None of the SSC functions associated with this subsystem are } \\
\text { credited for the prevention or mitigation of a preclosure event sequence. }\end{array}$ \\
\hline \multicolumn{5}{|c|}{ Transportation Cask Receipt/Return Facility } \\
\hline $\begin{array}{l}\text { Cask Receipt and } \\
\text { Return Area }\end{array}$ & Structure & ITS & $\mathrm{sc}$ & $\begin{array}{l}\text { - The load carrying members of the structure shall: } \\
\text { be designed for the loads associated with a design basis extreme wind speed. } \\
\text { (BSC 2004g Section 6.1.1.2 and BSC 2004d Section 9) } \\
\text { (2) be designed for the loads associated with a design basis tornado maximum } \\
\text { wind speed with a corresponding pressure drop and rate of pressure drop. } \\
\text { (BSC 2004g Section 4.2.2.3.7 and BSC 2004d Section 9) } \\
\text { (3) not allow the penetration of Spectrum II tornado missiles, except for the } \\
\text { entrance and exit vestibules. (BSC 2004d Section 9) } \\
\text { - The roof of the structure shall be designed for the loads associated with the } \\
\text { maximum observed hourly precipitation event (with a 100-year return period). (BSC } \\
\text { 2004g Section 6.1.1.1.2 and BSC 2005b Section 4.3.2) } \\
\text { - Facilities that could be damaged by flooding shall be located above the probable } \\
\text { maximum flood elevation or must be appropriately protected from the probable } \\
\text { maximum flood. (BSC 2004g Section 6.1.2.1 and BSC 2005b Section 4.3.2) } \\
\text { - The structure shall be designed such that storm water runoff from the maximum } \\
\text { observed hourly precipitation event (with a } 100-y e a r \text { return period) does not enter the } \\
\text { structure. (BSC 2004g Section 6.1.1.1.2 and BSC 2005b Section 4.3.2) } \\
\text { - The roof of the structure shall be designed for the loads associated with a volcanic } \\
\text { ash fall. (BSC 2004b Section 6.4.53) } \\
\text { - The TCRRF load-carrying members shall be designed for loading conditions } \\
\text { associated with a DBGM-2 seismic event. In addition, an analysis shall demonstrate } \\
\text { that the TCRRF load carrying members have sufficient seismic design margin to } \\
\text { ensure that a "no structural collapse" safety function }{ }^{3} \text { is maintained for loading } \\
\text { conditions associated with a BDBGM seismic event. (BSC 2004a Table IV-1) } \\
\text { - The severity of potential fires shall not jeopardize the structural integrity of structures } \\
\text { where SNF/HLW is present. (BSC 2004c Section 5.1.3.2) }\end{array}$ \\
\hline
\end{tabular}


Table A-I. Nuclear Safety Design Bases of Facilities

\begin{tabular}{|c|c|c|c|c|}
\hline $\begin{array}{l}\text { Facility, System, or } \\
\text { Subsystem }\end{array}$ & $\begin{array}{l}\text { Component or } \\
\text { Function }\end{array}$ & $\begin{array}{l}\text { ITS or } \\
\text { ITWI }\end{array}$ & $\begin{array}{l}\text { Safety } \\
\text { Category }\end{array}$ & Nuclear Safety Design Bases \\
\hline $\begin{array}{l}\text { Cask Receipt and } \\
\text { Return Area } \\
\text { (continued) }\end{array}$ & Structure (continued) & ITS & SC & $\begin{array}{l}\text { - Portions, parts, subparts, or subsystems of a non-ITS SSC, which upon failure could } \\
\text { adversely interact with an ITS SSC and prevent its safety function from being } \\
\text { performed, shall be classified as ITS or redesigned to eliminate the potential } \\
\text { unacceptable interaction with the identified ITS SSC. For seismic interactions, } \\
\text { portions, parts, subparts, or subsystems of an otherwise non-ITS SSC shall be } \\
\text { classified as ITS and shall be designed to the same seismic DBGM as the ITS SSCs } \\
\text { subjected to the potential unacceptable interaction, or the non-ITS SSC may be } \\
\text { redesigned to eliminate the potential unacceptable interaction. (BSC 2005b Section } \\
\text { 5.1.1.37) }\end{array}$ \\
\hline $\begin{array}{l}\text { Transportation Cask } \\
\text { Buffer Area }\end{array}$ & Structure & N/A & Non-SC & $\begin{array}{l}\text { Not Applicable. None of the SSC functions associated with this subsystem are } \\
\text { credited for the prevention or mitigation of an event sequence. }\end{array}$ \\
\hline \multicolumn{5}{|c|}{ Warehouse \& Non-Nuclear Receipt Facility } \\
\hline WNNRF & Structure & N/A & Non-SC & $\begin{array}{l}\text { Not Applicable. No function of this facility is credited for the prevention or mitigation of } \\
\text { an event sequence. }\end{array}$ \\
\hline
\end{tabular}

NOTES: $B$ DBGM = beyond design basis ground motion; CHF = Canister Handling Facility; DBGM = design basis ground motion; DTF = Dry Transfer Facility; FHF = Fuel Handling Facility; ITS = important to safety; SC = safety category; SRTC = site rail transfer cart; SSC = structure, system, or component; SSCs = structures, systems, and components; TCRRF = Transportation Cask Receipt and Return Facility; WNNRF = Warehouse and Non-Nuclear Receipt Facility. 
8
0
$\dot{d}$
0
0
1
0
0
0
0
0
0
0
0
0
0
0
0
0

$\stackrel{P}{\stackrel{D}{N}}$

INTENTIONALLY LEFT BLANK

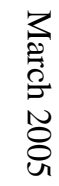


Table A-II. Nuclear Safety Design Bases of Systems and Subsystems

\begin{tabular}{|c|c|c|c|c|}
\hline $\begin{array}{l}\text { System or } \\
\text { Subsystem }\end{array}$ & $\begin{array}{l}\text { Component } \\
\text { or Function }\end{array}$ & $\begin{array}{l}\text { ITS or } \\
\text { ITWI }\end{array}$ & $\begin{array}{l}\text { Safety } \\
\text { Category }\end{array}$ & Nuclear Safety Design Bases \\
\hline \multicolumn{5}{|c|}{ Cask/MSC/WP Preparation System } \\
\hline Cask Preparation & $\begin{array}{l}\text { Cask Handling } \\
\text { Crane (CHF); } \\
200 \text { ton }\end{array}$ & ITS & SC & $\begin{array}{l}\text { - The drop rate for cranes involved in handling waste forms and their associated } \\
\text { containers shall be less than or equal to } 1 \times 10^{-5} \text { drops/transfer, regardless of cause, } \\
\text { including human error, failure of equipment such as yokes and grapples, or a combination } \\
\text { of the two. (BSC 2005b Section } 5.1 .1 .10 \text { ) } \\
\text { - Upon a loss of power, this crane shall be designed to stop, retain its load, and enter a } \\
\text { locked mode; upon a restoration of power, this crane shall stay in the locked mode until } \\
\text { operator action is taken. (BSC } 2005 b \text { Section } 5.1 .2 .1 \text { ) } \\
\text { - The conditional probability of the crane exceeding a lift-height limit, given that a drop has } \\
\text { occurred, shall be less than or equal to } 1 \times 10^{-4} \text {. (BSC 2005b Section 5.1.1.12) } \\
\text { - The lift height limits for the casks handled by this crane are provided in Table C-1 in } \\
\text { Appendix C, including the following: } \\
\text { 1. Transportation casks without impact limiters containing naval SNF canisters. } \\
\text { 2. Transportation casks without impact limiters containing standardized DOE SNF } \\
\text { canisters. } \\
\text { 3. Transportation casks without impact limiters containing DOE HLW canisters and } \\
\text { commercial SNF in vertical DPCs. } \\
\text { 4. Transportation casks without impact limiters containing a DOE MCO. } \\
\text { 5. Site specific casks with vertical DPCs. } \\
\text { - This crane and its rigging shall be designed for loading conditions associated with a } \\
\text { DBGM-2 seismic event and to demonstrate sufficient seismic design margin to ensure that } \\
\text { a "no drop" safety function is maintained for loading conditions associated with a BDBGM } \\
\text { seismic event. (BSC } 2004 a \text { Table IV-1) } \\
\text { - This crane shall not be capable of moving above a speed limit for overhead crane } \\
\text { transfers such that a collision at the speed limit would not breach a transportation cask or } \\
\text { site-specific cask. (BSC } 2005 b \text { Section } 5.1 .1 .19 \text { ) }\end{array}$ \\
\hline
\end{tabular}


Table A-II. Nuclear Safety Design Bases of Systems and Subsystems

\begin{tabular}{|c|c|c|c|c|}
\hline $\begin{array}{l}\text { System or } \\
\text { Subsystem }\end{array}$ & $\begin{array}{l}\text { Component } \\
\text { or Function }\end{array}$ & $\begin{array}{l}\text { ITS or } \\
\text { ITWI }\end{array}$ & $\begin{array}{l}\text { Safety } \\
\text { Category }\end{array}$ & Nuclear Safety Design Bases \\
\hline \multirow[t]{2}{*}{$\begin{array}{l}\text { Cask Preparation } \\
\text { (continued) }\end{array}$} & $\begin{array}{l}\text { Cask Handling } \\
\text { Crane (CHF); } \\
200 \text { ton } \\
\text { (continued) }\end{array}$ & ITS & SC & $\begin{array}{l}\text { - This crane shall not be capable of exerting sufficient force during transfer to breach a } \\
\text { cask as the result of attempts to overcome mechanical constraints. (BSC } 2005 \mathrm{~b} \text { Section } \\
5.1 .1 .20 \text { ) } \\
\text { - In the event of a credible fire in an area where waste forms are present, the temperature } \\
\text { of the crane that handles or transports SNF/HLW shall not reach a level that would make it } \\
\text { drop its load. (BSC } 2004 \mathrm{c} \text { Section } 5.1 .3 .1 \text { ) } \\
\text { - A drop of a load from a crane that handles SNF/HLW due to a spurious signal caused by } \\
\text { a fire shall have a probability of less than } 1 \times 10^{-4} \text { over the life of the facility. (BSC } 2004 \mathrm{C} \\
\text { Section 5.1.3.4; BSC } 2005 \mathrm{~b} \text { Section } 6.1 .1 .1 \text { ) }\end{array}$ \\
\hline & $\begin{array}{l}\text { Cask Handling } \\
\text { Crane (DTF); } \\
200 \text { ton }\end{array}$ & ITS & $\mathrm{SC}$ & $\begin{array}{l}\text { - The drop rate for cranes involved in handling waste forms and their associated } \\
\text { containers shall be less than or equal to } 1 \times 10^{-5} \text { drops/transfer, regardless of cause, } \\
\text { including human error, failure of equipment such as yokes and grapples, or a combination } \\
\text { of the two. (BSC } 2005 \mathrm{~b} \text { Section } 5.1 .1 .10 \text { ) } \\
\text { - Upon a loss of power, this crane shall be designed to stop, retain its load, and enter a } \\
\text { locked mode; upon a restoration of power, this crane shall stay in the locked mode until } \\
\text { operator action is taken. (BSC } 2005 \mathrm{~b} \text { Section } 5.1 .2 .1 \text { ) } \\
\text { - The conditional probability of the crane exceeding a lift-height limit, given that a drop has } \\
\text { occurred, shall be less than or equal to } 1 \times 10^{-4} \text {. (BSC } 2005 \mathrm{~b} \text { Section 5.1.1.12) } \\
\text { - The lift height limits for the casks handled by this crane are provided in Table C-1 in } \\
\text { Appendix C; these casks include: } \\
\text { 1. Transportation casks without impact limiters containing standardized DOE SNF } \\
\text { canisters, DOE HLW canisters, commercial SNF, or vertical or horizontal DPCs. } \\
\text { 2. Site-specific casks containing commercial SNF or vertical or horizontal DPCs. } \\
\text { 3. Transportation casks without impact limiters containing a DOE MCO. } \\
\text { - This crane and its rigging shall be designed for loading conditions associated with a } \\
\text { DBGM-2 seismic event and to demonstrate sufficient seismic design margin to ensure that } \\
\text { a "no drop" safety function }{ }^{3} \text { is maintained for loading conditions associated with a BDBGM } \\
\text { seismic event. (BSC } 2004 a \text { Table IV-1) }\end{array}$ \\
\hline
\end{tabular}


Table A-II. Nuclear Safety Design Bases of Systems and Subsystems

\begin{tabular}{|c|c|c|c|c|}
\hline $\begin{array}{l}\text { System or } \\
\text { Subsystem }\end{array}$ & $\begin{array}{l}\text { Component } \\
\text { or Function }\end{array}$ & $\begin{array}{l}\text { ITS or } \\
\text { ITWI }\end{array}$ & $\begin{array}{l}\text { Safety } \\
\text { Category }\end{array}$ & Nuclear Safety Design Bases \\
\hline \multirow[t]{2}{*}{$\begin{array}{l}\text { Cask Preparation } \\
\text { (continued) }\end{array}$} & $\begin{array}{l}\text { Cask Handling } \\
\text { Crane (DTF); } \\
200 \text { ton } \\
\text { (continued) }\end{array}$ & ITS & SC & $\begin{array}{l}\text { - This crane shall not be capable of moving above a speed limit for overhead crane } \\
\text { transfers such that a collision at the speed limit would not breach a transportation cask or } \\
\text { site-specific cask. (BSC } 2005 \mathrm{~b} \text { Section } 5.1 .1 .19 \text { ) } \\
\text { - This crane shall not be capable of exerting sufficient force during transfer to breach a } \\
\text { cask as the result of attempts to overcome mechanical constraints. (BSC } 2005 \mathrm{~b} \text { Section } \\
5.1 .1 .20 \text { ) } \\
\text { - In the event of a credible fire in an area where waste forms are present, the temperature } \\
\text { of the crane that handles or transports SNF/HLW shall not reach a level that would make it } \\
\text { drop its load. (BSC } 2004 \mathrm{c} \text { Section } 5.1 .3 .1 \text { ) } \\
\text { - A drop of a load from a crane that handles SNF/HLW due to a spurious signal caused by } \\
\text { a fire shall have a probability of less than } 1 \times 10^{-4} \text { over the life of the facility. (BSC } 2004 \mathrm{c} \\
\text { Section 5.1.3.4; BSC } 2005 \text { b Section } 6.1 .1 .1 \text { ) }\end{array}$ \\
\hline & $\begin{array}{l}\text { Naval Cask } \\
\text { Handling Crane } \\
\text { (DTF); } 200 \text { ton }\end{array}$ & ITS & SC & $\begin{array}{l}\text { - The drop rate for cranes involved in handling waste forms and their associated } \\
\text { containers shall be less than or equal to } 1 \times 10^{-5} \mathrm{drops} / \mathrm{transfer} \text {, regardless of cause, } \\
\text { including human error, failure of equipment such as yokes and grapples, or a combination } \\
\text { of the two. (BSC 2005b Section } 5.1 .1 .10 \text { ) } \\
\text { - Upon a loss of power, this crane shall be designed to stop, retain its load, and enter a } \\
\text { locked mode; upon a restoration of power, this crane shall stay in the locked mode until } \\
\text { operator action is taken. (BSC } 2005 \mathrm{~b} \text { Section } 5.1 .2 .1 \text { ) } \\
\text { - The conditional probability of the crane exceeding a lift-height limit, given that a drop has } \\
\text { occurred, shall be less than or equal to } 1 \times 10^{-4} \text {. (BSC } 2005 \mathrm{~b} \text { Section 5.1.1.12) } \\
\text { - The lift height limit for transportation casks without impact limiters containing a naval } \\
\text { SNF canister is provided in Table C-1 in Appendix C. } \\
\text { - This crane and its rigging shall be designed for loading conditions associated with a } \\
\text { DBGM-2 seismic event and to demonstrate sufficient seismic design margin to ensure that } \\
\text { a "no drop" safety function is maintained for loading conditions associated with a BDBGM } \\
\text { seismic event. (BSC 2004a Table IV-1) }\end{array}$ \\
\hline
\end{tabular}


Table A-II. Nuclear Safety Design Bases of Systems and Subsystems

\begin{tabular}{|c|c|c|c|c|}
\hline $\begin{array}{l}\text { System or } \\
\text { Subsystem }\end{array}$ & $\begin{array}{l}\text { Component } \\
\text { or Function }\end{array}$ & $\begin{array}{l}\text { ITS or } \\
\text { ITWI }\end{array}$ & $\begin{array}{l}\text { Safety } \\
\text { Category }\end{array}$ & Nuclear Safety Design Bases \\
\hline \multirow[t]{3}{*}{$\begin{array}{l}\text { Cask Preparation } \\
\text { (continued) }\end{array}$} & $\begin{array}{l}\text { Naval Cask } \\
\text { Handling Crane } \\
\text { (DTF); } 200 \text { ton } \\
\text { (continued) }\end{array}$ & ITS & SC & $\begin{array}{l}\text { - This crane shall not be capable of moving above a speed limit for overhead crane } \\
\text { transfers such that a collision at the speed limit would not breach a naval SNF } \\
\text { transportation cask. (BSC } 2005 \text { b Section } 5.1 .1 .19 \text { ) } \\
\text { - This crane shall not be capable of exerting sufficient force during transfer to breach a } \\
\text { naval SNF transportation cask as the result of attempts to overcome mechanical } \\
\text { constraints. (BSC } 2005 \text { b Section } 5.1 .1 .20 \text { ) } \\
\text { - In the event of a credible fire in an area where waste forms are present, the temperature } \\
\text { of the crane that handles or transports SNF/HLW shall not reach a level that would make it } \\
\text { drop its load. (BSC } 2004 \mathrm{c} \text { Section } 5.1 .3 .1 \text { ) } \\
\text { - A drop of a load from a crane that handles SNF/HLW due to a spurious signal caused by } \\
\text { a fire shall have a probability of less than } 1 \times 10^{-4} \text { over the life of the facility. (BSC } 2004 \mathrm{c} \\
\text { Section 5.1.3.4; BSC } 2005 \text { b Section } 6.1 .1 .1 \text { ) }\end{array}$ \\
\hline & $\begin{array}{l}\text { Crane Lifting } \\
\text { Yokes }\end{array}$ & ITS & $\mathrm{SC}$ & $\begin{array}{l}\text { - Crane lifting yokes shall be designed for loading conditions associated with a DBGM-2 } \\
\text { seismic event and to demonstrate sufficient seismic design margin to ensure that a "no } \\
\text { drop" safety function }{ }^{3} \text { is maintained for loading conditions associated with a BDBGM } \\
\text { seismic event. (BSC 2004a Table IV-1) }\end{array}$ \\
\hline & Turntables (DTF) & ITS & SC & $\begin{array}{l}\text { - Turntables shall be designed for stability and prevention of a tipover of any waste } \\
\text { container on the table for loading conditions associated with a DBGM- } 2 \text { seismic event. In } \\
\text { addition, an analysis shall demonstrate that the turntable has sufficient seismic design } \\
\text { margin to ensure that a "no tipover" safety function }{ }^{3} \text { is maintained for loading conditions } \\
\text { associated with a BDBGM seismic event. (BSC } 2004 \text { a Table IV-1) } \\
\text { - In the event of a credible fire in an area where waste forms are present, the temperature } \\
\text { of machinery that handles or transports SNF/HLW shall not reach a level that would cause } \\
\text { a drop of a cask while on a turntable. (BSC } 2004 \mathrm{c} \text { Section } 5.1 .3 .1 \text { ) } \\
\text { - A tipover and breach of a cask while on a turntable that handles SNF/HLW due to } \\
\text { uncontrolled movements produced by a loss of power or a spurious signal caused by a fire } \\
\text { shall have a probability of less than } 1 \times 10^{-4} \text { over the life of the facility. (BSC } 2004 \mathrm{C} \\
\text { Section 5.1.3.4; BSC 2005b Section } 6.1 .1 .1 \text { ) }\end{array}$ \\
\hline
\end{tabular}




\begin{tabular}{|c|c|c|c|c|}
\hline $\begin{array}{l}\text { System or } \\
\text { Subsystem }\end{array}$ & $\begin{array}{l}\text { Component } \\
\text { or Function }\end{array}$ & $\begin{array}{l}\text { ITS or } \\
\text { ITWI }\end{array}$ & $\begin{array}{l}\text { Safety } \\
\text { Category }\end{array}$ & Nuclear Safety Design Bases \\
\hline \multirow[t]{5}{*}{$\begin{array}{l}\text { Cask Preparation } \\
\text { (continued) }\end{array}$} & $\begin{array}{l}\text { Cask Docking } \\
\text { Rings (DTF, FHF) }\end{array}$ & $\mathrm{N} / \mathrm{A}$ & Non-SC & $\begin{array}{l}\text { Not applicable. No function of this SSC is credited for the prevention or mitigation of an } \\
\text { event sequence. }\end{array}$ \\
\hline & $\begin{array}{l}\text { Cask Pit, } \\
\text { Pedestal; } \\
\text { (CHF) }\end{array}$ & N/A & Non-SC & $\begin{array}{l}\text { Not applicable. No function of this SSC is credited for the prevention or mitigation of an } \\
\text { event sequence. }\end{array}$ \\
\hline & $\begin{array}{l}\text { Cask Pit } \\
\text { Protective Cover } \\
\text { (CHF) }\end{array}$ & ITS & SC & $\begin{array}{l}\text { - The cask pit protective cover shall be designed for loading conditions associated with a } \\
\text { DBGM-1 seismic event and demonstrate sufficient seismic design margin to a "shielding } \\
\text { integrity remains intact" safety function }{ }^{3} \text {. (BSC 2004a Table IV-1) } \\
\text { - The cask pit protective cover shall be sturdy enough to prevent a WP or site-specific } \\
\text { cask that is dropped on the pit cover from penetrating the pit cover and falling into the pit. } \\
\text { (BSC 2005b Section 5.1.6.6) } \\
\text { - Radiation exposure to workers due to inadvertent actuation of the pit protective covers } \\
\text { shall be precluded such that this is not a Category } 1 \text { event. (BSC 2005b Section 5.1.1.57) }\end{array}$ \\
\hline & $\begin{array}{l}\text { Pit Crush Pads } \\
\text { (CHF) }\end{array}$ & ITS & SC & $\begin{array}{l}\text { - Crush pads shall limit the impact energy of a dropped canister, cask, or WP to be less } \\
\text { than or equal to the impact energy associated with a drop of a canister, cask, or WP onto } \\
\text { an unyielding surface from their maximum specified drop height for the canister, cask, or } \\
\text { WP'. (BSC 2005b Section 5.1.1.18) }\end{array}$ \\
\hline & $\begin{array}{l}\text { Vestibule Gantry } \\
\text { Crane } \\
\text { (FHF); } 200 \text { ton }\end{array}$ & ITS & SC & $\begin{array}{l}\text { - The drop rate for cranes involved in handling waste forms and their associated } \\
\text { containers shall be less than or equal to } 1 \times 10^{-5} \text { drops/transfer, regardless of cause, } \\
\text { including human error, failure of equipment such as yokes and grapples, or a combination } \\
\text { of the two. (BSC 2005b Section 5.1.1.10) } \\
\text { - Upon a loss of power, this crane shall be designed to stop, retain its load, and enter a } \\
\text { locked mode; upon a restoration of power, this crane shall stay in the locked mode until } \\
\text { operator action is taken. (BSC } 2005 \mathrm{~b} \text { Section } 5.1 .2 .1 \text { ) } \\
\text { - The conditional probability of the crane exceeding a lift-height limit, given that a drop has } \\
\text { occurred, shall be less than or equal to } 1 \times 10^{-4} \text {. (BSC 2005b Section 5.1.1.12) }\end{array}$ \\
\hline
\end{tabular}




\begin{tabular}{|c|c|c|c|c|}
\hline $\begin{array}{l}\text { System or } \\
\text { Subsystem }\end{array}$ & $\begin{array}{l}\text { Component } \\
\text { or Function }\end{array}$ & $\begin{array}{l}\text { ITS or } \\
\text { ITWI }\end{array}$ & $\begin{array}{l}\text { Safety } \\
\text { Category }\end{array}$ & Nuclear Safety Design Bases \\
\hline $\begin{array}{l}\text { Cask Preparation } \\
\text { (continued) }\end{array}$ & $\begin{array}{l}\text { Vestibule Gantry } \\
\text { Crane } \\
\text { (FHF); } 200 \text { ton } \\
\text { (continued) }\end{array}$ & ITS & SC & $\begin{array}{l}\text { - The lift height limits for the transportation casks handled by this crane are provided in } \\
\text { Table C-1 in Appendix C; these casks include: } \\
\text { 1. Transportation cask without impact limiters containing naval SNF canisters. } \\
\text { 2. Transportation cask without impact limiters containing standardized DOE SNF } \\
\text { canisters or DOE HLW canisters. } \\
\text { 3. Transportation cask without impact limiters or site-specific cask containing } \\
\text { commercial SNF or DPCs. } \\
\text { - This crane and its rigging shall be designed for loading conditions associated with a } \\
\text { DBGM-2 seismic event and to demonstrate sufficient seismic design margin to ensure that } \\
\text { a "no drop" safety function }{ }^{3} \text { is maintained for loading conditions associated with a BDBGM } \\
\text { seismic event. (BSC } 2004 \text { a Table IV-1) } \\
\text { - This crane shall not be capable of moving above a speed limit for overhead crane } \\
\text { transfers such that a collision at the speed limit would not breach a transportation cask or } \\
\text { site-specific cask. (BSC 2005b Section 5.1.1.19) } \\
\text { - This crane shall not be capable of exerting sufficient force during transfer to breach a } \\
\text { cask, WP, or site-specific cask as the result of attempts to overcome mechanical } \\
\text { constraints. (BSC 2005b Section 5.1.1.20) } \\
\text { - In the event of a credible fire in an area where waste forms are present, the temperature } \\
\text { of the crane that handles or transports SNF/HLW shall not reach a level that would make it } \\
\text { drop its load. (BSC 2004c Section 5.1.3.1) } \\
\text { - A drop of a load from a crane that handles SNF/HLW due to a spurious signal caused by } \\
\text { a fire shall have a probability of less than } 1 \times 10^{-4} \text { over the life of the facility. (BSC } 2004 \mathrm{c} \\
\text { Section 5.1.3.4; BSC 2005b Section 6.1.1.1) }\end{array}$ \\
\hline & $\begin{array}{l}\text { Main Transfer } \\
\text { Room Crane } \\
\text { (FHF); } 200 \text { ton }\end{array}$ & ITS & SC & $\begin{array}{l}\text { - The drop rate for cranes involved in handling waste forms and their associated } \\
\text { containers shall be less than or equal to } 1 \times 10^{-5} \text { drops/transfer, regardless of cause, } \\
\text { including human error, failure of equipment such as yokes and grapples, or a combination } \\
\text { of the two. (BSC 2005b Section 5.1.1.10) } \\
\text { - The probability of dropping handling equipment from a crane onto a canister shall be } \\
\text { less than or equal to } 1 \times 10^{-5} \text { for each canister transferred. (BSC 2005b Section 5.1.1.11) }\end{array}$ \\
\hline
\end{tabular}




\begin{tabular}{|c|c|c|c|c|}
\hline $\begin{array}{l}\text { System or } \\
\text { Subsystem }\end{array}$ & $\begin{array}{l}\text { Component } \\
\text { or Function }\end{array}$ & $\begin{array}{l}\text { ITS or } \\
\text { ITWI }\end{array}$ & $\begin{array}{l}\text { Safety } \\
\text { Category }\end{array}$ & Nuclear Safety Design Bases \\
\hline $\begin{array}{l}\text { Cask Preparation } \\
\text { (continued) }\end{array}$ & $\begin{array}{l}\text { Main Transfer } \\
\text { Room Crane } \\
\text { (FHF); } 200 \text { ton } \\
\text { (continued) }\end{array}$ & ITS & SC & 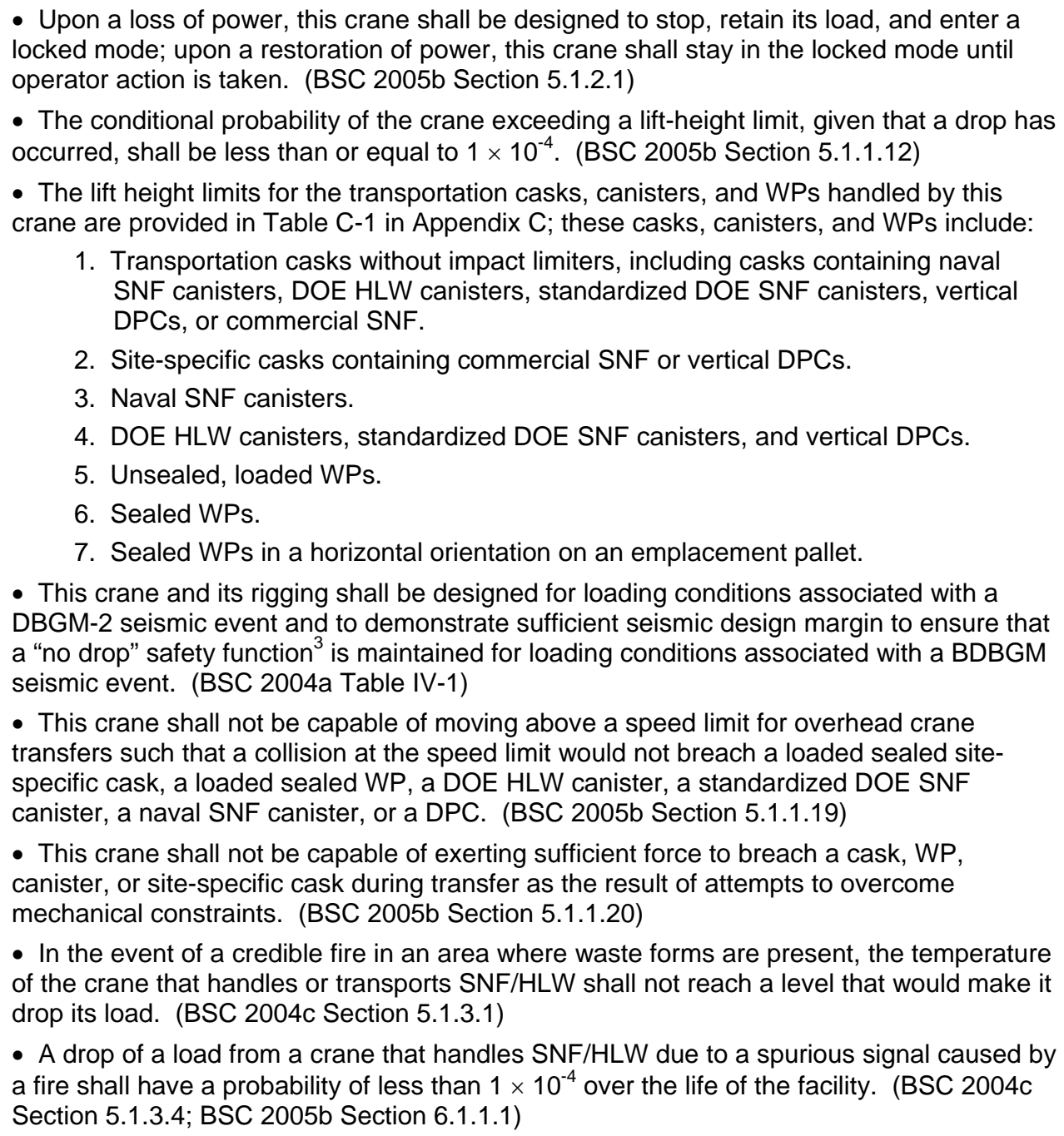 \\
\hline
\end{tabular}


Table A-II. Nuclear Safety Design Bases of Systems and Subsystems

\begin{tabular}{|c|c|c|c|c|}
\hline $\begin{array}{l}\text { System or } \\
\text { Subsystem }\end{array}$ & $\begin{array}{l}\text { Component } \\
\text { or Function }\end{array}$ & $\begin{array}{l}\text { ITS or } \\
\text { ITWI }\end{array}$ & $\begin{array}{l}\text { Safety } \\
\text { Category }\end{array}$ & Nuclear Safety Design Bases \\
\hline \multirow[t]{3}{*}{$\begin{array}{l}\text { Cask Preparation } \\
\text { (continued) }\end{array}$} & $\begin{array}{l}\text { Mobile Elevating } \\
\text { Platform }\end{array}$ & N/A & Non-SC & $\begin{array}{l}\text { Not applicable. No function of this SSC is credited for the prevention or mitigation of an } \\
\text { event sequence. }\end{array}$ \\
\hline & $\begin{array}{l}\text { Pit Movable } \\
\text { Platforms (CHF) }\end{array}$ & $\mathrm{N} / \mathrm{A}$ & Non-SC & $\begin{array}{l}\text { Not applicable. No function of this SSC is credited for the prevention or mitigation of an } \\
\text { event sequence. }\end{array}$ \\
\hline & $\begin{array}{l}\text { Cask Trolleys, } \\
\text { Pedestals, and } \\
\text { Hold-Down } \\
\text { Devices (DTF, } \\
\text { FHF) }\end{array}$ & ITS & SC & $\begin{array}{l}\text { - Upon a loss of power, this trolley shall be designed to stop, retain its load, and enter a } \\
\text { locked mode; upon a restoration of power, this trolley shall stay in the locked mode until } \\
\text { operator action is taken. (BSC } 2005 \text { b Section } 5.1 .2 .2 \text { ) } \\
\text { - The trolley system shall be designed for loading conditions associated with a DBGM-2 } \\
\text { seismic event to maintain trolley stability and prevent waste container slapdown. In } \\
\text { addition, an analysis shall demonstrate that the trolley system has sufficient seismic design } \\
\text { margin to ensure that a "no slapdown" safety function is maintained for loading conditions } \\
\text { associated with a BDBGM seismic event. (BSC } 2004 a \text { Table IV-1) } \\
\text { - Pedestals and hold-down devices shall be designed for loading conditions associated } \\
\text { with a DBGM-2 seismic event and to demonstrate sufficient seismic design margin to } \\
\text { ensure that a "no tipover" safety function is maintained for loading conditions associated } \\
\text { with a BDBGM seismic event. (BSC } 2004 \text { a Table IV-1) } \\
\text { - The trolley shall be designed with an inherent speed limit such that a collision at the } \\
\text { trolley speed limit would not cause the trolley to drop its load. (BSC } 2005 \mathrm{~b} \text { Section } \\
5.1 .1 .61 \text { ) } \\
\text { - Loaded transfer trolleys shall not derail or drop their loads. (BSC } 2005 \mathrm{~b} \text { Section } \\
5.1 .1 .36 \text { ) } \\
\text { - In the event of a credible fire in an area where waste forms are present, the temperature } \\
\text { of the machinery that handles or transports SNF/HLW shall not reach a level that would } \\
\text { make it drop its load. (BSC } 2004 \mathrm{C} \text { Section } 5.1 .3 .1 \text { ) } \\
\text { - A tipover and breach of a cask while on machinery that transports SNF/HLW due to } \\
\text { uncontrolled movements produced by a loss of power or a spurious signal caused by a fire } \\
\text { shall have a probability of less than } 1 \times 10^{-4} \text { over the life of the facility. (BSC } 2004 \mathrm{c} \\
\text { Section } 5.1 .3 .4 \text {; BSC } 2005 \mathrm{~b} \text { Section } 6.1 .1 .1 \text { ) }\end{array}$ \\
\hline
\end{tabular}




\begin{tabular}{|c|c|c|c|c|}
\hline $\begin{array}{l}\text { System or } \\
\text { Subsystem }\end{array}$ & $\begin{array}{l}\text { Component } \\
\text { or Function }\end{array}$ & $\begin{array}{l}\text { ITS or } \\
\text { ITWI }\end{array}$ & $\begin{array}{l}\text { Safety } \\
\text { Category }\end{array}$ & Nuclear Safety Design Bases \\
\hline \multirow[t]{2}{*}{ WP Preparation } & $\begin{array}{l}\text { WP Trolleys, } \\
\text { Pedestals, and } \\
\text { Hold-Down } \\
\text { Devices (DTF, } \\
\text { CHF, FHF) }\end{array}$ & ITS & SC & $\begin{array}{l}\text { - Upon a loss of power, this trolley shall be designed to stop, retain its load, and enter a } \\
\text { locked mode; upon a restoration of power, this trolley shall stay in the locked mode until } \\
\text { operator action is taken. (BSC } 2005 \text { b Section } 5.1 .2 .2 \text { ) } \\
\text { - WP trolleys shall be designed for loading conditions associated with a DBGM-2 seismic } \\
\text { event and to demonstrate sufficient seismic design margin to ensure that a "no tipover" } \\
\text { safety function }{ }^{3} \text { is maintained for loading conditions associated with a BDBGM seismic } \\
\text { event. (BSC } 2004 \text { a Table IV-1) } \\
\text { - Pedestals and hold-down devices shall be designed for loading conditions associated } \\
\text { with a DBGM-2 seismic event and to demonstrate sufficient seismic design margin to } \\
\text { ensure that a "no slapdown" safety function }{ }^{3} \text { is maintained for loading conditions } \\
\text { associated with a BDBGM seismic event. (BSC } 2004 \text { a Table IV-1) } \\
\text { - The trolley shall be designed with an inherent speed limit such that a collision at the } \\
\text { trolley speed limit would not cause the trolley to drop its load. (BSC } 2005 \text { b Section } \\
5.1 .1 .61 \text { ) } \\
\text { - Loaded transfer trolleys shall not derail or drop their loads. (BSC } 2005 b \text { Section } \\
5.1 .1 .36 \text { ) } \\
\text { - In the event of a credible fire in an area where waste forms are present, the temperature } \\
\text { of the machinery that handles or transports SNF/HLW shall not reach a level that would } \\
\text { make it drop its load. (BSC } 2004 c \text { Section } 5.1 .3 .1 \text { ) } \\
\text { - A tipover and breach of a cask while on machinery that transports SNF/HLW due to } \\
\text { uncontrolled movements produced by a loss of power or a spurious signal caused by a fire } \\
\text { shall have a probability of less than } 1 \times 10^{-4} \text { over the life of the facility. (BSC } 2004 \mathrm{c} \\
\text { Section } 5.1 .3 .4 \text {; BSC } 2005 \text { bection } 6.1 .1 .1 \text { ) }\end{array}$ \\
\hline & $\begin{array}{l}\text { WP Docking Ring } \\
\text { (DTF, FHF) }\end{array}$ & N/A & Non-SC & $\begin{array}{l}\text { Not applicable. No function of this SSC is credited for the prevention or mitigation of an } \\
\text { event sequence. }\end{array}$ \\
\hline
\end{tabular}




\begin{tabular}{|c|c|c|c|c|}
\hline $\begin{array}{l}\text { System or } \\
\text { Subsystem }\end{array}$ & $\begin{array}{l}\text { Component } \\
\text { or Function }\end{array}$ & $\begin{array}{l}\text { ITS or } \\
\text { ITWI }\end{array}$ & $\begin{array}{l}\text { Safety } \\
\text { Category }\end{array}$ & Nuclear Safety Design Bases \\
\hline $\begin{array}{l}\text { WP Preparation } \\
\text { (continued) }\end{array}$ & $\begin{array}{l}\text { WP and Canister } \\
\text { Handling Crane } \\
\text { (CHF); } 100 \text { ton }\end{array}$ & ITS & SC & 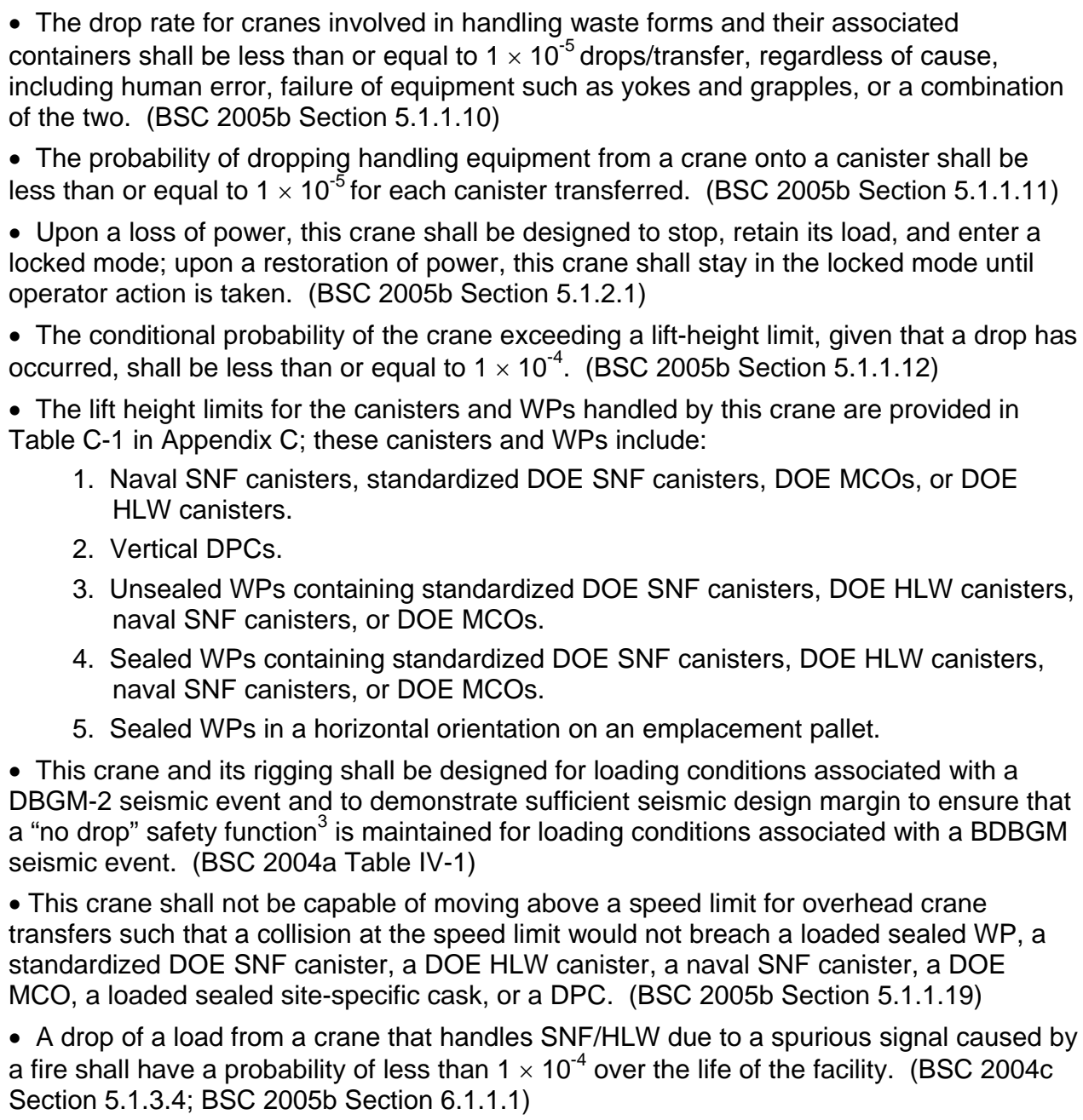 \\
\hline
\end{tabular}




\begin{tabular}{|c|c|c|c|c|}
\hline $\begin{array}{l}\text { System or } \\
\text { Subsystem }\end{array}$ & $\begin{array}{l}\text { Component } \\
\text { or Function }\end{array}$ & $\begin{array}{l}\text { ITS or } \\
\text { ITWI }\end{array}$ & $\begin{array}{l}\text { Safety } \\
\text { Category }\end{array}$ & Nuclear Safety Design Bases \\
\hline \multirow[t]{5}{*}{$\begin{array}{l}\text { WP Preparation } \\
\text { (continued) }\end{array}$} & $\begin{array}{l}\text { WP and Canister } \\
\text { Handling Crane } \\
\text { (CHF); } 100 \text { ton } \\
\text { (continued) }\end{array}$ & ITS & SC & $\begin{array}{l}\text { - This crane shall not be capable of exerting sufficient force during transfer to breach a } \\
\text { canister or WP as the result of attempts to overcome mechanical constraints. (BSC } 2005 \mathrm{~b} \\
\text { Section 5.1.1.20) } \\
\text { - In the event of a credible fire in an area where waste forms are present, the temperature } \\
\text { of the crane that handles or transports SNF/HLW shall not reach a level that would make it } \\
\text { drop its load. (BSC 2004c Section 5.1.3.1) }\end{array}$ \\
\hline & $\begin{array}{l}\text { Crane Lifting } \\
\text { Yokes }\end{array}$ & ITS & SC & $\begin{array}{l}\text { - Crane lifting yokes shall be designed for loading conditions associated with a DBGM-2 } \\
\text { seismic event and to demonstrate sufficient seismic margin to ensure that a "no drop" } \\
\text { safety function }{ }^{3} \text { is maintained for loading conditions associated with a BDBGM seismic } \\
\text { event. (BSC 2004a Table IV-1) }\end{array}$ \\
\hline & $\begin{array}{l}\text { WP/MSC Pit } \\
\text { Protective Covers } \\
\text { (CHF) }\end{array}$ & ITS & SC & $\begin{array}{l}\text { - The WP/MSC pit protective covers shall be designed for loading conditions associated } \\
\text { with a DBGM-1 seismic event and demonstrate sufficient seismic design margin to a "no } \\
\text { failure" safety function }{ }^{3} \text {. (BSC 2004a Table IV-1) } \\
\text { - Pit covers shall be sturdy enough to prevent a WP or site-specific cask that is dropped } \\
\text { on the pit cover from penetrating the pit cover and falling into the pit. (BSC 2005b Section } \\
5.1 .6 .6 \text { ) } \\
\text { - Radiation exposure to workers due to inadvertent actuation of the pit protective covers } \\
\text { shall be precluded such that this is not a Category } 1 \text { event. (BSC 2005b Section 5.1.1.57) }\end{array}$ \\
\hline & $\begin{array}{l}\text { WP/MSC Pit } \\
\text { Pedestals (CHF) }\end{array}$ & N/A & Non-SC & $\begin{array}{l}\text { Not applicable. No function of this SSC is credited for the prevention or mitigation of an } \\
\text { event sequence. }\end{array}$ \\
\hline & Crush Pad & ITS & SC & $\begin{array}{l}\text { - Crush pads shall limit the impact energy of a dropped unsealed WP to be less than or } \\
\text { equal to the impact energy associated with a drop of an unsealed WP onto an unyielding } \\
\text { surface from the maximum specified drop height for the unsealed WP6. (BSC 2005b } \\
\text { Section 5.1.1.50) }\end{array}$ \\
\hline Cask Restoration & Entire & $N / A$ & Non-SC & $\begin{array}{l}\text { Not applicable. None of the SSC functions associated with this subsystem are credited for } \\
\text { the prevention or mitigation of an event sequence. }\end{array}$ \\
\hline
\end{tabular}


Table A-II. Nuclear Safety Design Bases of Systems and Subsystems

\begin{tabular}{|c|c|c|c|c|}
\hline $\begin{array}{l}\text { System or } \\
\text { Subsystem }\end{array}$ & $\begin{array}{l}\text { Component } \\
\text { or Function }\end{array}$ & $\begin{array}{l}\text { ITS or } \\
\text { ITWI }\end{array}$ & $\begin{array}{l}\text { Safety } \\
\text { Category }\end{array}$ & Nuclear Safety Design Bases \\
\hline \multicolumn{5}{|c|}{ Cask Receipt and Return System } \\
\hline \multirow[t]{5}{*}{ SRTC Buffer } & SRTC & ITS & SC & $\begin{array}{l}\text { - In the instances when the SRTC moves a cask without impact limiters (typically only } \\
\text { within structures), the SRTC shall prevent slapdown of the cask for loading conditions } \\
\text { associated with a DBGM-2 seismic event. In addition, an analysis shall demonstrate that } \\
\text { the SRTC transporting a cask without impact limiters has sufficient seismic design margin } \\
\text { to ensure that a "no slapdown" safety function }{ }^{3} \text { is maintained for loading conditions } \\
\text { associated with a BDBGM seismic event. (BSC 2004a Table IV-1) } \\
\text { - A speed limit for which SRTCs will be pulled/pushed by the SRTC tractor shall be } \\
\text { established such that a collision with shield or airlock doors or other heavy objects does } \\
\text { not overturn the SRTC or cause it to lose its load. (BSC 2005b Section 5.1.1.38) } \\
\text { - In the instances where the SRTC moves a cask without impact limiters (typically only } \\
\text { within structures) an SRTC carrying a transportation cask or a site-specific cask shall not } \\
\text { derail and the transportation cask or site-specific cask shall not fall from the SRTC under } \\
\text { normal operating conditions or as the result of a collision. (BSC 2005b Section 5.1.1.35) }\end{array}$ \\
\hline & SRTC Rails & N/A & Non-SC & $\begin{array}{l}\text { Not applicable. No function of this SSC is credited for the prevention or mitigation of an } \\
\text { event sequence. }\end{array}$ \\
\hline & SRTC Positioner & N/A & Non-SC & $\begin{array}{l}\text { Not applicable. No function of this SSC is credited for the prevention or mitigation of an } \\
\text { event sequence. }\end{array}$ \\
\hline & $\begin{array}{l}\text { SRTC Positioner } \\
\text { Turntable }\end{array}$ & N/A & Non-SC & $\begin{array}{l}\text { Not applicable. No function of this SSC is credited for the prevention or mitigation of an } \\
\text { event sequence. }\end{array}$ \\
\hline & SRTC Tractor & N/A & Non-SC & $\begin{array}{l}\text { Not applicable. No function of this SSC is credited for the prevention or mitigation of an } \\
\text { event sequence. }\end{array}$ \\
\hline
\end{tabular}


Table A-II. Nuclear Safety Design Bases of Systems and Subsystems

\begin{tabular}{|c|c|c|c|c|}
\hline $\begin{array}{l}\text { System or } \\
\text { Subsystem }\end{array}$ & $\begin{array}{l}\text { Component } \\
\text { or Function }\end{array}$ & $\begin{array}{l}\text { ITS or } \\
\text { ITWI }\end{array}$ & $\begin{array}{l}\text { Safety } \\
\text { Category }\end{array}$ & Nuclear Safety Design Bases \\
\hline $\begin{array}{l}\text { Cask Receipt and } \\
\text { Return }\end{array}$ & $\begin{array}{l}\text { Cask Handling } \\
\text { Crane (TCRRF); } \\
250 \text { ton }\end{array}$ & ITS & $\mathrm{SC}$ & 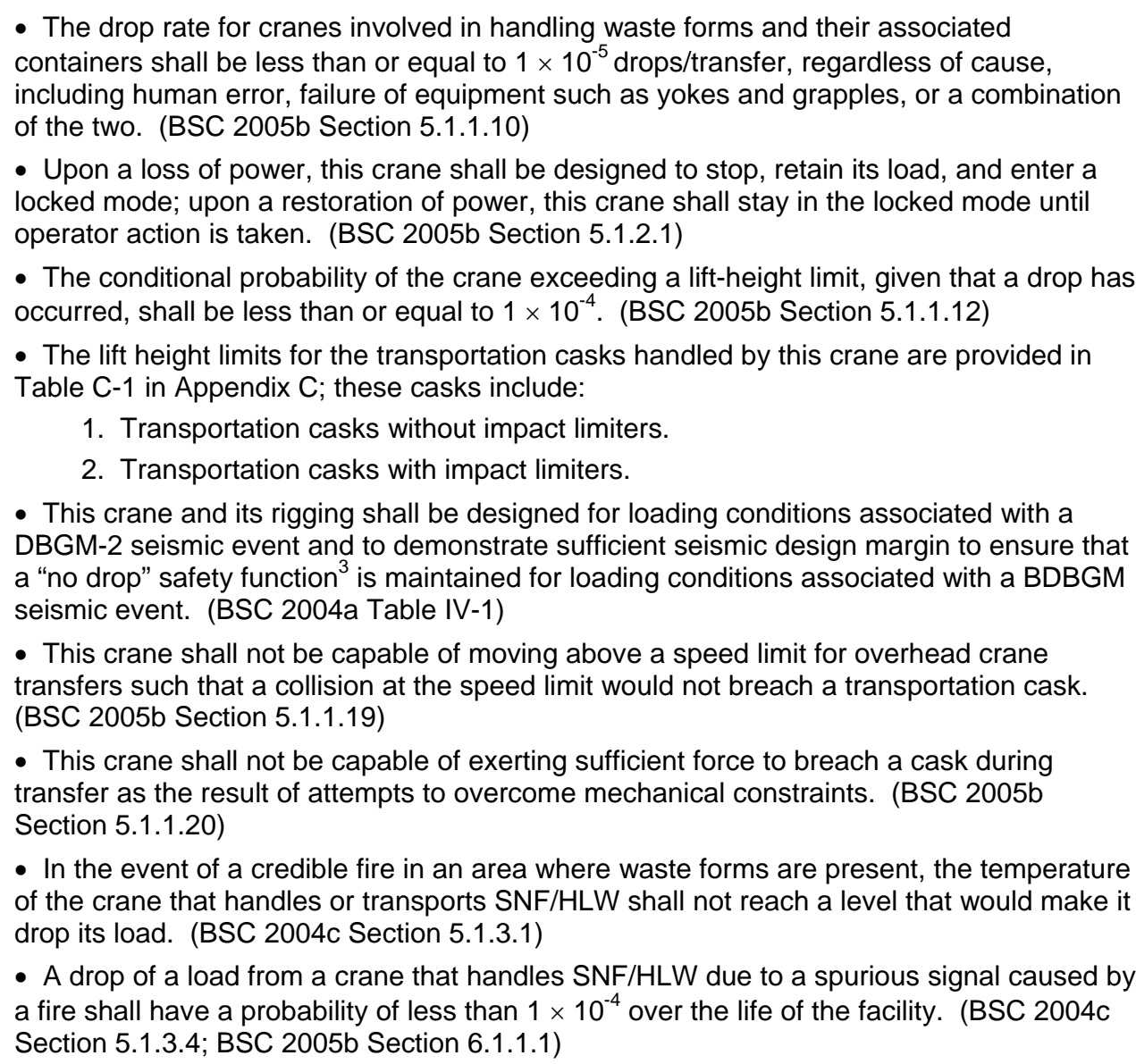 \\
\hline
\end{tabular}




\begin{tabular}{|c|c|c|c|c|}
\hline $\begin{array}{l}\text { System or } \\
\text { Subsystem }\end{array}$ & $\begin{array}{l}\text { Component } \\
\text { or Function }\end{array}$ & $\begin{array}{l}\text { ITS or } \\
\text { ITWI }\end{array}$ & $\begin{array}{l}\text { Safety } \\
\text { Category }\end{array}$ & Nuclear Safety Design Bases \\
\hline \multirow[t]{2}{*}{$\begin{array}{l}\text { Cask Receipt and } \\
\text { Return (continued) }\end{array}$} & $\begin{array}{l}\text { Crane Lifting } \\
\text { Yokes }\end{array}$ & ITS & SC & $\begin{array}{l}\text { - The crane lifting yokes shall be designed for loading conditions associated with a } \\
\text { DBGM-2 seismic event and to demonstrate sufficient seismic margin to ensure that a "no } \\
\text { drop" safety function }{ }^{3} \text { is maintained for loading conditions associated with a BDBGM } \\
\text { seismic event. (BSC 2004a Table IV-1) }\end{array}$ \\
\hline & Crush Pad & ITS & $\mathrm{SC}$ & $\begin{array}{l}\text { - Crush pads shall limit the impact energy of a dropped cask to be less than or equal to } \\
\text { the impact energy associated with a drop of a cask onto an unyielding surface from the } \\
\text { maximum specified drop height for the cask }{ }^{6} \text {. (BSC 2005b Section 5.1.1.18) }\end{array}$ \\
\hline \multicolumn{5}{|r|}{ Communications System } \\
\hline Communications & Entire & N/A & Non-SC & $\begin{array}{l}\text { Not applicable. None of the SSC functions associated with these subsystems are credited } \\
\text { for the prevention or mitigation of an event sequence. }\end{array}$ \\
\hline \multicolumn{5}{|c|}{ Digital Control and Management Information System } \\
\hline $\begin{array}{l}\text { Digital Control and } \\
\text { Management } \\
\text { Information }\end{array}$ & Entire & N/A & Non-SC & $\begin{array}{l}\text { Not applicable. No function of this SSC is credited for the prevention or mitigation of an } \\
\text { event sequence. }\end{array}$ \\
\hline \multicolumn{5}{|c|}{ DOE and Commercial WP System } \\
\hline $\begin{array}{l}\text { DOE and } \\
\text { Commercial WP }\end{array}$ & Entire & $\begin{array}{l}\text { ITS } \\
\text { ITWI }\end{array}$ & $\mathrm{SC}$ & $\begin{array}{l}\text { - Sealed WPs shall withstand without breaching the following drops: (BSC } 2005 \mathrm{~b} \text { Section } \\
\text { 5.1.3.12) } \\
\text { A. Free-drop of } 6.5 \mathrm{ft} \text { from a vertical orientation onto a horizontal surface (trunnion } \\
\text { collars installed) } \\
\text { B. Free-drop of } 7.8 \mathrm{ft} \text { from a horizontal orientation onto a horizontal surface (trunnion } \\
\text { collars installed) } \\
\text { C. Free-drop with the emplacement pallet from a horizontal orientation onto a horizontal } \\
\text { surface (trunnion collars not installed) of } 6.5 \mathrm{ft} \text { from the bottom of the emplacement } \\
\text { pallet }\end{array}$ \\
\hline
\end{tabular}


Table A-II. Nuclear Safety Design Bases of Systems and Subsystems

\begin{tabular}{|c|c|c|c|c|}
\hline $\begin{array}{l}\text { System or } \\
\text { Subsystem }\end{array}$ & $\begin{array}{l}\text { Component } \\
\text { or Function }\end{array}$ & $\begin{array}{l}\text { ITS or } \\
\text { ITWI }\end{array}$ & $\begin{array}{l}\text { Safety } \\
\text { Category }\end{array}$ & Nuclear Safety Design Bases \\
\hline $\begin{array}{l}\text { DOE and } \\
\text { Commercial WP } \\
\text { (continued) }\end{array}$ & Entire (continued) & $\begin{array}{l}\text { ITS } \\
\text { ITWI }\end{array}$ & SC & $\begin{array}{l}\text { - Sealed WPs shall withstand without breaching the following drops (continued): (BSC } \\
\text { 2005b Section 5.1.3.12) } \\
\text { D. Tip-over onto a horizontal surface from a } 6.5 \text { ft elevated surface (trunnion collars } \\
\text { installed) } \\
\text { E. Tip-over onto the tilting machine, including contact with the trunnion cradles or the } \\
\text { floor (trunnion collars installed). } \\
\text { Note: Drop and tip-over event sequences shall be evaluated for worst possible (most } \\
\text { damaging) credible conditions including initial geometric position and weight of } \\
\text { contents. An unyielding, flat horizontal surface may be used to bound the } \\
\text { consequences of a drop. Drops shall include attendant swing-down and/or slap- } \\
\text { down from the indicated position, with or without trunnion collars attached, as } \\
\text { appropriate. } \\
\text { - WPs, in a horizontal orientation on an emplacement pallet, shall be lifted in accordance } \\
\text { with the lift height limits in Table C-1 in Appendix C. } \\
\text { - WPs in a vertical orientation shall be lifted in accordance with the lift height limits in } \\
\text { Table C-1 in Appendix C. } \\
\text { - WPs shall withstand a single rockfall of } 1.2 \times 10^{5} \text { joules or less without breaching. (BSC } \\
\text { 2005b Section } 6.3 .6 .1 .20 \text { ) } \\
\text { - WPs shall withstand two consecutive rockfalls having a total kinetic energy of } 1.0 \times 10^{5} \\
\text { joules or less without breaching. (BSC } 2005 b \text { Section } 6.3 .6 .1 .20 \text { ) } \\
\text { - WPs shall be designed for loading conditions associated with a DBGM-2 seismic event } \\
\text { and to demonstrate sufficient seismic design margin to ensure that "no breach" and "no } \\
\text { criticality" safety functions are maintained for loading conditions associated with a BDBGM } \\
\text { seismic event. (BSC 2004a Table IV-1) } \\
\text { - The size of the berth in a WP shall be restricted such that a DOE MCO cannot be tilted } \\
\text { more than an angle of } 3 \text { degrees from vertical upon impact with the floor of the berth. } \\
\text { (BSC } 2005 b \text { Section } 5.1 .1 .15 \text { ) } \\
\text { - In the event of a credible fire, the wall temperature of a loaded but unsealed WP with } \\
\text { only the inner lid installed (welded or not) shall not exceed its allowable operating range } \\
\text { (BSC } 2004 \text { c Section } 5.1 .2 .10 \text { ) }\end{array}$ \\
\hline
\end{tabular}


Table A-II. Nuclear Safety Design Bases of Systems and Subsystems

\begin{tabular}{|c|c|c|c|c|}
\hline $\begin{array}{l}\text { System or } \\
\text { Subsystem }\end{array}$ & $\begin{array}{l}\text { Component } \\
\text { or Function }\end{array}$ & $\begin{array}{l}\text { ITS or } \\
\text { ITWI }\end{array}$ & $\begin{array}{l}\text { Safety } \\
\text { Category }\end{array}$ & Nuclear Safety Design Bases \\
\hline $\begin{array}{l}\text { DOE and } \\
\text { Commercial WP } \\
\text { (continued) }\end{array}$ & Entire (continued) & $\begin{array}{l}\text { ITS } \\
\text { ITWI }\end{array}$ & SC & $\begin{array}{l}\text { - In the event of a credible fire, the wall temperature of a sealed WP shall not exceed its } \\
\text { allowable operating range }{ }^{5} \text {. (BSC } 2004 \mathrm{c} \text { Section } 5.1 .2 .11 \text { ) } \\
\text { - In the event of a credible fire, the wall temperature of an open, loaded WP with a } \\
\text { docking ring installed shall not exceed its allowable operating range }{ }^{2,5} \text {. (BSC } 2004 \mathrm{c} \\
\text { Section 5.1.2.17) } \\
\text { - A WP shall not breach as a result of the credible fire } 5 \\
\text { - Sealed WPs shall be designed such that drops, collisions, and other handling impacts } \\
\text { within the WP design bases (allowing for rearrangement of container internals and without } \\
\text { credit for burnup) cannot lead to a nuclear criticality. (BSC } 2005 \mathrm{~b} \text { Section } 5.1 .3 .1 \text { ) } \\
\text { - WPs shall be designed, with credit for moderator control, such that: (BSC 2005b } \\
\text { Section 5.1.3.2) } \\
\text { A. WPs configured for commercial SNF can be loaded with any combination of } \\
\text { commercial SNF assemblies that are acceptable for disposal without leading } \\
\text { to a preclosure nuclear criticality. } \\
\text { B. DOE codisposal WPs can be loaded with any combination of DOE canisters } \\
\text { that fit in the basket positions without leading to a preclosure nuclear criticality. } \\
\text { The demonstration of criticality safety must account for the bowing of fuel rods } \\
\text { or other rearrangement of fissile material that may occur due to a drop or other } \\
\text { handling incident. } \\
\text { - A WP that is dropped from within } 2 \mathrm{ft} \text { above an essentially unyielding flat surface shall } \\
\text { not Spill its contents. (BSC } 2005 \mathrm{~b} \text { Section } 5.1 .3 .11 \text { ) }\end{array}$ \\
\hline & Trunnion Collar & ITS & SC & $\begin{array}{l}\text { - Trunnion collars shall be designed for loading conditions associated with a DBGM-2 } \\
\text { seismic event and to demonstrate sufficient seismic design margin to ensure a "no drop" } \\
\text { safety function }{ }^{3} \text { is maintained for loading conditions associated with a BDBGM seismic } \\
\text { event. (BSC 2004a Table IV-1) }\end{array}$ \\
\hline
\end{tabular}


Table A-II. Nuclear Safety Design Bases of Systems and Subsystems

\begin{tabular}{|c|c|c|c|c|}
\hline $\begin{array}{c}\text { System or } \\
\text { Subsystem }\end{array}$ & $\begin{array}{c}\text { Component } \\
\text { or Function }\end{array}$ & $\begin{array}{c}\text { ITS or } \\
\text { ITWI }\end{array}$ & $\begin{array}{c}\text { Safety } \\
\text { Category }\end{array}$ & Nuclear Safety Design Bases \\
\hline
\end{tabular}

DOE SNF Disposable Canister

\begin{tabular}{l|l|l|l|l} 
DOE SNF & $\begin{array}{l}\text { Standardized } \\
\text { Disposable }\end{array}$ & ITS & SC & $\begin{array}{l}\text { The probability that a standardized DOE SNF canister is defective such that it may } \\
\text { breach if dropped in any orientation from a height of } 23 \mathrm{ft} \text { onto an essentially unyielding }\end{array}$
\end{tabular}

Canister

DOE SNF

breach if dropped in any orientation from a height of $23 \mathrm{ft}$ onto
surface shall be $2.3 \times 10^{-4}$ or less. (BSC $2005 \mathrm{~b}$ Section 4.2.2)

- A standardized DOE SNF canister in a cask, WP, staging rack, or staging pit, shall withstand without breach a drop of a DOE HLW canister onto it from $2 \mathrm{ft}$ above the floor of the transfer cell and from $23 \mathrm{ft}$ above the floor of the cask, WP, staging rack, or staging pit. (BSC 2005b Section 5.1.1.25)

- A standardized DOE SNF canister shall not breach if lifted in accordance with the lift height limits in Table C-1 in Appendix C.

- A standardized DOE SNF canister shall be designed for loading conditions associated with a DBGM-2 seismic event and to demonstrate sufficient seismic margin to ensure that "no breach" and "no criticality" safety functions ${ }^{3}$ are maintained for loading conditions associated with a BDBGM seismic event. (BSC 2004a Table IV-1)

- A standardized DOE SNF canister shall withstand without breach a drop of another standardized DOE SNF canister drop on top of it from $23 \mathrm{ft}$ above the floor of a cask, WP, staging rack or staging pit and from $2 \mathrm{ft}$ above the floor of the transfer cell. (BSC 2005b Section 5.1.1.28)

- A drop of a standardized DOE SNF canister shall not lead to a nuclear criticality assuming that the canister is not breached and moderator control is in effect. (BSC 2005b Section 5.1.1.3)

- In the event of a credible fire, the wall temperature of a DOE standardized canister shall not exceed its allowable operating range. The operating temperature of a standardized DOE SNF canister, when it is not inside another canister, is $149{ }^{\circ} \mathrm{C}(300 \mathrm{~F})$, and $316{ }^{\circ} \mathrm{C}$ $\left(600{ }^{\circ} \mathrm{F}\right)$, after placement into another canister. Containment can be maintained for temperatures as high as $343^{\circ} \mathrm{C}\left(650^{\circ} \mathrm{F}\right)^{5}$. (BSC 2004c Section 5.1.2.5)

- A standardized DOE SNF canister shall not breach as a result of the credible fire ${ }^{5}$. 
Table A-II. Nuclear Safety Design Bases of Systems and Subsystems

\begin{tabular}{|c|c|c|c|c|}
\hline $\begin{array}{l}\text { System or } \\
\text { Subsystem }\end{array}$ & $\begin{array}{l}\text { Component } \\
\text { or Function }\end{array}$ & $\begin{array}{l}\text { ITS or } \\
\text { ITWI }\end{array}$ & $\begin{array}{l}\text { Safety } \\
\text { Category }\end{array}$ & Nuclear Safety Design Bases \\
\hline $\begin{array}{l}\text { DOE SNF } \\
\text { Disposable } \\
\text { Canister } \\
\text { (continued) }\end{array}$ & DOE MCO & ITS & SC & $\begin{array}{l}\text { - The probability that a DOE MCO is defective such that it may breach if dropped from } \\
\text { less than a height of } 23 \mathrm{ft} \text { in less than a 3-degree vertical orientation or } 2 \mathrm{ft} \text { from any } \\
\text { orientation shall be } 2.3 \times 10^{-4} \text { or less. (BSC } 2005 \mathrm{~b} \text { Section } 4.2 .2 \text { ) } \\
\text { - A DOE MCO in a cask or WP shall withstand without breach a drop of a DOE HLW } \\
\text { canister onto it from } 2 \mathrm{ft} \text { above the floor of the transfer cell and from } 23 \mathrm{ft} \text { above the floor of } \\
\text { the cask or WP. (BSC } 2005 \mathrm{~b} \text { Section } 5.1 .1 .25 \text { ) } \\
\text { - A DOE MCO shall withstand without breach a drop of another DOE MCO onto it from } 2 \mathrm{ft} \\
\text { above the floor of the transfer cell and from } 23 \mathrm{ft} \text { above the floor of the cask or WP. (BSC } \\
2005 \mathrm{~b} \text { Section } 5.1 .1 .28 \text { ) } \\
\text { - A DOE MCO shall not breach if dropped in accordance with the lift height limits in Table } \\
\text { C-1 in Appendix C. } \\
\text { - A DOE MCO shall be designed for loading conditions associated with a DBGM-2 seismic } \\
\text { event and to demonstrate sufficient seismic design margin to ensure that "no breach" and } \\
\text { "no criticality" safety functions }{ }^{3} \text { are maintained for loading conditions associated with a } \\
\text { BDBGM seismic event. (BSC } 2004 a \text { Table IV-1) } \\
\text { - A drop of a DOE MCO shall not lead to a nuclear criticality assuming that the canister is } \\
\text { not breached and moderator control is in effect. (BSC } 2005 b \text { Section } 5.1 .1 .3 \text { ) } \\
\text { - In the event of a credible fire, the wall temperature of a DOE MCO shall not exceed its } \\
\text { allowable operating range. The most restrictive temperature is the handling temperature, } \\
132{ }^{\circ} \mathrm{C}^{5} \text {. (BSC } 2004 \mathrm{C} \text { Section } 5.1 .2 .6 \text { ) } \\
\text { - A DOE MCO shall not breach as a result of the credible fire }{ }^{5} \text {. }\end{array}$ \\
\hline & $\begin{array}{l}\text { DOE HLW } \\
\text { Canister }\end{array}$ & ITS & SC & $\begin{array}{l}\text { - A DOE HLW canister shall be designed for loading conditions associated with a } \\
\text { DBGM-1 seismic event and to demonstrate sufficient seismic design margin to a "no } \\
\text { breach" safety function }{ }^{3} \text {. (BSC 2004a Table IV-1) } \\
\text { - A DOE HLW canister shall not be subjected to a temperature exceeding its allowable } \\
\text { operating range; the temperature limit of the waste form inside the canister is } 400^{\circ} \mathrm{C}^{5} \text {. } \\
\text { (BSC 2004c Section 5.1.2.7) }\end{array}$ \\
\hline
\end{tabular}




\begin{tabular}{|c|c|c|c|c|}
\hline $\begin{array}{l}\text { System or } \\
\text { Subsystem }\end{array}$ & $\begin{array}{l}\text { Component } \\
\text { or Function }\end{array}$ & $\begin{array}{l}\text { ITS or } \\
\text { ITWI }\end{array}$ & $\begin{array}{l}\text { Safety } \\
\text { Category }\end{array}$ & Nuclear Safety Design Bases \\
\hline \multirow[t]{2}{*}{$\begin{array}{l}\text { DOE SNF } \\
\text { Disposable } \\
\text { Canister } \\
\text { (continued) }\end{array}$} & $\begin{array}{l}\text { Internal Geometry } \\
\text { Control }\end{array}$ & ITS & SC & $\begin{array}{l}\text { - The DOE SNF disposable canister internal geometry control shall be designed for } \\
\text { loading conditions associated with a DBGM-2 seismic event and to demonstrate sufficient } \\
\text { seismic design margin to ensure that a "no criticality" safety function }{ }^{3} \text { is maintained for } \\
\text { loading conditions associated with a BDBGM seismic event. (BSC 2004a Table IV-1) }\end{array}$ \\
\hline & $\begin{array}{l}\text { Internal Neutron } \\
\text { Absorbers }\end{array}$ & ITWI & SC & $\begin{array}{l}\text { - No function of this SSC is credited for the prevention or mitigation of a preclosure event } \\
\text { sequence. }\end{array}$ \\
\hline \multicolumn{5}{|r|}{ Dual Purpose Canister } \\
\hline DPC & Entire & ITS & $\mathrm{SC}$ & $\begin{array}{l}\text { - In the event of a credible fire, the wall temperature of a loaded DPC, being handled or at } \\
\text { rest, shall not exceed its allowable operating range }{ }^{5} \text {. (BSC 2004c Section 5.1.2.9) } \\
\text { - A DPC shall not breach as a result of the credible fire } \text {. }^{5} \\
\text { - DPCs shall be designed to ensure nuclear criticality safety with optimum moderation and } \\
\text { the most reactive waste forms. Criticality safety will be maintained despite any geometric } \\
\text { rearrangements due to a drop or other handling incident. (BSC 2005b Section 5.1.1.4) }\end{array}$ \\
\hline \multicolumn{5}{|r|}{ Electrical Power System } \\
\hline Switchyard & $\begin{array}{l}\text { Line End } \\
\text { Transmission } \\
\text { Tower; Line Side } \\
\text { High Voltage } \\
\text { Disconnect } \\
\text { Switch; High } \\
\text { Voltage Breaker } \\
\text { (continued on next } \\
\text { page) }\end{array}$ & ITS & $\mathrm{SC}$ & $\begin{array}{l}\text { - Electrical power system components shall provide reliable power to the DTF and FHF } \\
\text { Surface Nuclear HVAC Primary Confinement Subsystem to meet the performance criteria } \\
\text { in accordance with the Surface Nuclear HVAC Primary Confinement Subsystem nuclear } \\
\text { safety design bases. (BSC 2005b Section 5.1.1.48, BSC 2004f Table 9) }\end{array}$ \\
\hline
\end{tabular}




\begin{tabular}{|c|c|c|c|c|}
\hline $\begin{array}{l}\text { System or } \\
\text { Subsystem }\end{array}$ & $\begin{array}{l}\text { Component } \\
\text { or Function }\end{array}$ & $\begin{array}{l}\text { ITS or } \\
\text { ITWI }\end{array}$ & $\begin{array}{l}\text { Safety } \\
\text { Category }\end{array}$ & Nuclear Safety Design Bases \\
\hline $\begin{array}{l}\text { Switchyard } \\
\text { (continued) }\end{array}$ & $\begin{array}{l}\text { (continued) Load } \\
\text { Side High Voltage } \\
\text { Disconnect } \\
\text { Switch; Main } \\
\text { Transformer; and } \\
\text { Nonsegmented } \\
\text { Bus to } 12.17 \mathrm{kV} \\
\text { Main Switchgear }\end{array}$ & ITS & SC & $\begin{array}{l}\text { Electrical power system components shall provide reliable power to the DTF and FHF } \\
\text { Surface Nuclear HVAC Primary Confinement Subsystem to meet the performance criteria } \\
\text { in accordance with the Surface Nuclear HVAC Primary Confinement Subsystem nuclear } \\
\text { safety design bases. (BSC 2005b Section 5.1.1.48, BSC 2004f Table 9) }\end{array}$ \\
\hline Normal Power & $\begin{array}{l}12.47 \mathrm{kV} \text { Main } \\
\text { Switchgear; } 12.47 \\
\mathrm{kV} \text { to } 4.16 \mathrm{kV} \\
\text { Distribution } \\
\text { Transformer to } \\
\text { Emergency } \\
\text { Switchgear Bus A; } \\
12.47 \mathrm{kV} \text { to } 4.16 \\
\mathrm{kV} \text { Distribution } \\
\text { Transformer to } \\
\text { Emergency } \\
\text { Switchgear Bus B }\end{array}$ & ITS & SC & $\begin{array}{l}\text { Electrical power system components shall provide reliable power to the DTF and FHF } \\
\text { Surface Nuclear HVAC Primary Confinement Subsystem to meet the performance criteria } \\
\text { in accordance with the Surface Nuclear HVAC Primary Confinement Subsystem nuclear } \\
\text { safety design bases. (BSC 2005b Section 5.1.1.48; BSC 2004f Table 9) }\end{array}$ \\
\hline & $\begin{array}{l}4.16 \mathrm{kV} \\
\text { Switchgear Bus A, } \\
\text { B, C, and D; } 12.47 \\
\mathrm{kV} \text { Switchgear C } \\
\text { and D (located at } \\
\text { South Portal), } \\
\text { Standby Diesel } \\
\text { Generators }\end{array}$ & N/A & Non-SC & $\begin{array}{l}\text { Not applicable. None of the SSC functions associated with this subsystem are credited for } \\
\text { the prevention or mitigation of an event sequence. }\end{array}$ \\
\hline
\end{tabular}




\begin{tabular}{|c|c|c|c|c|}
\hline $\begin{array}{l}\text { System or } \\
\text { Subsystem }\end{array}$ & $\begin{array}{l}\text { Component } \\
\text { or Function }\end{array}$ & $\begin{array}{l}\text { ITS or } \\
\text { ITWI }\end{array}$ & $\begin{array}{l}\text { Safety } \\
\text { Category }\end{array}$ & Nuclear Safety Design Bases \\
\hline \multirow[t]{2}{*}{ Emergency Power } & $\begin{array}{l}4.16 \mathrm{kV} \\
\text { Emergency } \\
\text { Switchgear Bus A } \\
\text { and B; Emergency } \\
\text { Load Center } \\
\text { Transformers for } \\
\text { DTF1, DTF2, and } \\
\text { FHF; Emergency } \\
\text { Load Centers and } \\
\text { MCC located in } \\
\text { DTF 1, DTF2, and } \\
\text { FHF; and Feeders } \\
\text { up to and } \\
\text { including the ITS } \\
\text { Loads }\end{array}$ & ITS & SC & $\begin{array}{l}\text { - Electrical power system components shall provide reliable power to the DTF and FHF } \\
\text { Surface Nuclear HVAC Primary Confinement Subsystem to meet the performance criteria } \\
\text { in accordance with the Surface Nuclear HVAC Primary Confinement Subsystem nuclear } \\
\text { safety design bases. (BSC 2005b Section 5.1.1.48, BSC 2004f Table 9) }\end{array}$ \\
\hline & $\begin{array}{l}\text { Emergency Diesel } \\
\text { Generators A } \\
\text { and B }\end{array}$ & N/A & Non-SC & $\begin{array}{l}\text { Not applicable. None of the SSC functions associated with this subsystem are credited for } \\
\text { the prevention or mitigation of an event sequence. }\end{array}$ \\
\hline \multicolumn{5}{|c|}{ Electrical Support System } \\
\hline Lighting & Entire & N/A & Non-SC & $\begin{array}{l}\text { Not applicable. None of the SSC functions associated with this subsystem are credited for } \\
\text { the prevention or mitigation of an event sequence. }\end{array}$ \\
\hline Grounding & Entire & N/A & Non-SC & $\begin{array}{l}\text { Not applicable. None of the SSC functions associated with this subsystem are credited for } \\
\text { the prevention or mitigation of an event sequence. }\end{array}$ \\
\hline $\begin{array}{l}\text { Lightning } \\
\text { Protection }\end{array}$ & Entire & N/A & Non-SC & $\begin{array}{l}\text { Not applicable. None of the SSC functions associated with this subsystem are credited for } \\
\text { the prevention or mitigation of an event sequence. }\end{array}$ \\
\hline $\begin{array}{l}\text { Cathodic } \\
\text { Protection }\end{array}$ & Entire & N/A & Non-SC & $\begin{array}{l}\text { Not applicable. None of the SSC functions associated with this subsystem are credited for } \\
\text { the prevention or mitigation of an event sequence. }\end{array}$ \\
\hline
\end{tabular}




\begin{tabular}{|c|c|c|c|c|}
\hline $\begin{array}{l}\text { System or } \\
\text { Subsystem }\end{array}$ & $\begin{array}{l}\text { Component } \\
\text { or Function }\end{array}$ & $\begin{array}{l}\text { ITS or } \\
\text { ITWI }\end{array}$ & $\begin{array}{l}\text { Safety } \\
\text { Category }\end{array}$ & Nuclear Safety Design Bases \\
\hline Heat Tracing & Entire & N/A & Non-SC & $\begin{array}{l}\text { Not applicable. None of the SSC functions associated with this subsystem are credited for } \\
\text { the prevention or mitigation of an event sequence. }\end{array}$ \\
\hline \multirow[t]{2}{*}{ Cable Raceway } & $\begin{array}{l}\text { The Portion of } \\
\text { Cable Raceway } \\
\text { Subsystem that } \\
\text { Supports ITS } \\
\text { Functions of the } \\
\text { Electrical Power } \\
\text { System (including } \\
\text { the switchyard, } \\
12.47 \mathrm{kV} \text { main } \\
\text { switchgear A and } \\
\mathrm{B}, 4.16 \mathrm{kV} \\
\text { emergency bus A } \\
\text { and B, } 480 \mathrm{~V} \\
\text { emergency load } \\
\text { centers and } \\
\text { MCCs, } 125 \mathrm{~V} \text { DC } \\
\text { and } 120 \mathrm{~V} \mathrm{AC} \\
\text { UPS }\end{array}$ & ITS & SC & $\begin{array}{l}\text { - The portion of the cable raceway subsystem that supports ITS functions of the } \\
\text { emergency power subsystem shall provide reliable power to the DTF and FHF Surface } \\
\text { Nuclear HVAC Primary Confinement System to meet the performance criteria in } \\
\text { accordance with the Surface Nuclear HVAC Primary Confinement System nuclear safety } \\
\text { design bases. (BSC 2005b Section 5.1.1.48) }\end{array}$ \\
\hline & $\begin{array}{l}\text { The Portion of } \\
\text { Cable Raceway } \\
\text { Subsystem that } \\
\text { Supports Non-SC } \\
\text { Functions of the } \\
\text { Electrical Power } \\
\text { System (including } \\
\text { portions of the } \\
\text { normal power } \\
\text { subsystem, } \\
\text { standby power } \\
\text { subsystem, and } \\
\text { emergency diesel } \\
\text { generators) }\end{array}$ & N/A & Non-SC & $\begin{array}{l}\text { Not applicable. None of the SSC functions associated with this subsystem are credited for } \\
\text { the prevention or mitigation of an event sequence. }\end{array}$ \\
\hline
\end{tabular}




\begin{tabular}{|c|c|c|c|c|}
\hline $\begin{array}{l}\text { System or } \\
\text { Subsystem }\end{array}$ & $\begin{array}{l}\text { Component } \\
\text { or Function }\end{array}$ & $\begin{array}{l}\text { ITS or } \\
\text { ITWI }\end{array}$ & $\begin{array}{l}\text { Safety } \\
\text { Category }\end{array}$ & Nuclear Safety Design Bases \\
\hline \multicolumn{5}{|c|}{ Emplacement and Retrieval System } \\
\hline $\begin{array}{l}\text { WP } \\
\text { Transportation }\end{array}$ & WP Transporter & ITS & $\mathrm{SC}$ & $\begin{array}{l}\text { - The WP transporter shall transport the WP in a manner such that if a collision or } \\
\text { derailment (excluding tipover) occurs, the WP impact energy will be low enough to } \\
\text { preclude a WP breach; this impact energy translates into a maximum WP transporter } \\
\text { speed of } 15 \text { mph. (BSC } 2005 \text { b Section 5.1.7.3) } \\
\text { - The WP transporter shall transport the WP in a manner such that if a collision or } \\
\text { derailment leading to a WP transporter tipover occurs, the WP impact energy will be low } \\
\text { enough to preclude a WP breach. (BSC 2005b Section 5.1.7.7) } \\
\text { - While on the surface, the WP transporter shall be designed to function in extreme } \\
\text { straight wind (90 mph). (BSC 2005b Section 4.1.13) } \\
\text { - The WP transporter and its bedplate shall not collide with a WP on the WP turntable and } \\
\text { cause a WP breach. (BSC 2005b Section 5.1.1.39) } \\
\text { - The rate of a WP transporter runaway shall be less than } 8.3 \times 10^{-9} \text { runaways per trip. } \\
\text { (BSC 2005b Section } 6.3 .6 .1 .4 \text { ) } \\
\text { - The WP transporter (together with the locomotive and coupler) shall be designed to } \\
\text { prevent runaway of the WP transporter for loading conditions associated with a DBGM-2 } \\
\text { seismic event. In addition, an analysis shall demonstrate that the WP transporter (together } \\
\text { with the locomotive and coupler) has sufficient seismic design margin to ensure that a "no } \\
\text { runaway" safety function }{ }^{3} \text { is maintained for loading conditions associated with a BDBGM } \\
\text { seismic event. (BSC 2004a Table IV-1) }\end{array}$ \\
\hline
\end{tabular}




\begin{tabular}{|c|c|c|c|c|}
\hline $\begin{array}{l}\text { System or } \\
\text { Subsystem }\end{array}$ & $\begin{array}{l}\text { Component } \\
\text { or Function }\end{array}$ & $\begin{array}{l}\text { ITS or } \\
\text { ITWI }\end{array}$ & $\begin{array}{l}\text { Safety } \\
\text { Category }\end{array}$ & Nuclear Safety Design Bases \\
\hline $\begin{array}{l}\text { WP } \\
\text { Transportation } \\
\text { (continued) }\end{array}$ & $\begin{array}{l}\text { WP Transporter } \\
\text { (continued) }\end{array}$ & ITS & SC & $\begin{array}{l}\text { - The WP transporter shall be designed for loading conditions associated with a DBGM-1 } \\
\text { seismic event and demonstrate sufficient seismic design margin to a "shielding integrity } \\
\text { remains intact" safety function }{ }^{3} \text {. (BSC } 2004 a \text { Table IV-1) } \\
\text { - The transporter shielded compartment shall withstand any fall of failed ground support } \\
\text { materials, as well as a set of rockfalls having a total mass of } 5.4 \text { MT, without jeopardizing } \\
\text { the structural integrity of the WP. (BSC } 2005 \text { b Section } 6.3 .6 .1 .9 \text { ) } \\
\text { - Movement of the WP transporter shielded enclosure doors shall not breach the WP or } \\
\text { cause it to fall from the bedplate of the transporter. (BSC 2005b Section 5.1.7.2) } \\
\text { - The restraints used to immobilize the bedplate inside the shielded compartment of the } \\
\text { WP transporter and the mechanism for locking the doors of the shielded compartment shall } \\
\text { withstand a collision or derailment (including tipover) of the transporter without resulting in } \\
\text { a Category } 1 \text { or Category } 2 \text { event sequence. (BSC 2005b Section 5.1.7.4) } \\
\text { - Spurious or operator-induced opening of the WP shielded compartment followed by a } \\
\text { bedplate roll-out shall be precluded when the transporter is in motion. (BSC } 2005 \mathrm{~b} \text { Section } \\
5.1 .7 .6 \text { ) } \\
\text { - Radiation exposure to workers due to inadvertent actuation of the WP transporter } \\
\text { shielded compartment doors shall be precluded such that this is not a Category } 1 \text { event. } \\
\text { (BSC 2005b Section 5.1.1.57) } \\
\text { - Upon a loss of power, the WP transporter shall be designed to stop, retain its load, and } \\
\text { enter a locked mode; upon a restoration of power, the WP transporter shall stay in the } \\
\text { locked mode until operator action is taken. (BSC 2005b Section 5.1.2.2) }\end{array}$ \\
\hline
\end{tabular}




\begin{tabular}{|c|c|c|c|c|}
\hline $\begin{array}{l}\text { System or } \\
\text { Subsystem }\end{array}$ & $\begin{array}{l}\text { Component } \\
\text { or Function }\end{array}$ & $\begin{array}{l}\text { ITS or } \\
\text { ITWI }\end{array}$ & $\begin{array}{l}\text { Safety } \\
\text { Category }\end{array}$ & Nuclear Safety Design Bases \\
\hline WP Emplacement & $\begin{array}{l}\text { WP Emplacement } \\
\text { Gantry }\end{array}$ & ITS & SC & $\begin{array}{l}\text { - The emplacement gantry shall have a drop rate of less than or equal to } 1 \times 10^{-5} \\
\text { drops/transfer regardless of the cause, including equipment failures, human error, or some } \\
\text { combination of the two. (BSC } 2005 \mathrm{~b} \text { Section } 5.1 .8 .1 \text { ) } \\
\text { - The lift height limit for WPs in a horizontal orientation on the emplacement pallet is } \\
\text { provided in Table C-1 in Appendix C. } \\
\text { - The WP emplacement gantry, carrying a WP, shall not be capable of running off the end } \\
\text { of the emplacement drift or transfer dock rails. (BSC } 2005 \text { b Section } 5.1 .8 .3 \text { ) } \\
\text { - If the WP emplacement gantry were to fall on the WP transporter and impact the WP, it } \\
\text { shall not cause the WP to be breached. (BSC } 2005 \mathrm{~b} \text { Section } 5.1 .8 .6 \text { ) } \\
\text { - The WP emplacement gantry shall be limited to a maximum speed of } 15 \text { mph such that a } \\
\text { collision at this speed limit shall not result in a WP breach. (BSC } 2005 \mathrm{~b} \text { Section } 5.1 .8 .7 \text { ) } \\
\text { - Upon a loss of power, the WP emplacement gantry shall be designed to stop, retain its } \\
\text { load, and enter a locked mode; upon a restoration of power, the WP emplacement gantry } \\
\text { shall stay in the locked mode until operator action is taken. (BSC } 2005 \mathrm{~b} \text { Section } 5.1 .2 .2 \text { ) } \\
\text { - The conditional probability of the WP emplacement gantry having exceeded the lift } \\
\text { height limit given that a drop occurred shall be } 10^{-4} \text { or less. (BSC } 2005 \mathrm{~b} \text { Section } 5.1 .8 .10 \text { ) } \\
\text { - In the event of a credible fire in an area where waste forms are present, the temperature } \\
\text { of machinery that handles or transports SNF/HLW shall not reach a level that would make } \\
\text { it drop its load. (BSC } 2004 \mathrm{C} \text { Section } 5.1 .3 .1 \text { ) } \\
\text { - A tipover and breach of a WP due to uncontrolled movements produced by a loss of } \\
\text { power or a spurious signal caused by a fire shall have a probability of less than } 1 \times 10^{-4} \\
\text { over the life of the facility. (BSC } 2004 \mathrm{c} \text { Section } 5.1 .3 .4 \text {; BSC } 2005 \mathrm{~b} \text { Section } 6.1 .1 .1 \text { ) }\end{array}$ \\
\hline WP Retrieval & $\begin{array}{l}\text { Components of } \\
\text { this System are } \\
\text { the same as those } \\
\text { in the WP } \\
\text { Transportation } \\
\text { and WP } \\
\text { Emplacement } \\
\text { Subsystems }\end{array}$ & ITS & SC & $\begin{array}{l}\text { The nuclear safety design bases for this system are the same as those in the WP } \\
\text { Transportation and WP Emplacement Subsystems since they share the same } \\
\text { components. }\end{array}$ \\
\hline
\end{tabular}




\begin{tabular}{|c|c|c|c|c|}
\hline $\begin{array}{l}\text { System or } \\
\text { Subsystem }\end{array}$ & $\begin{array}{l}\text { Component } \\
\text { or Function }\end{array}$ & $\begin{array}{l}\text { ITS or } \\
\text { ITWI }\end{array}$ & $\begin{array}{l}\text { Safety } \\
\text { Category }\end{array}$ & Nuclear Safety Design Bases \\
\hline \multirow[t]{2}{*}{$\begin{array}{l}\text { Support } \\
\text { Equipment }\end{array}$} & $\begin{array}{l}\text { Transport } \\
\text { Locomotive }\end{array}$ & ITS & SC & $\begin{array}{l}\text { - The transport locomotive (together with the WP transporter and coupler) shall be } \\
\text { designed to prevent the runaway of the WP transporter for loading conditions associated } \\
\text { with a DBGM-2 seismic event. In addition, an analysis shall demonstrate that the transport } \\
\text { locomotive (together with the WP transporter and coupler) has sufficient seismic design } \\
\text { margin to ensure that a "no runaway" safety function }{ }^{3} \text { is maintained for loading conditions } \\
\text { associated with a BDBGM seismic event. (BSC 2004a Table IV-1) } \\
\text { - In the event of a credible fire in an area where waste forms are present, the temperature } \\
\text { of machinery that handles or transports SNF/HLW shall not reach a level that would make } \\
\text { it drop its load. (BSC 2004c Section 5.1.3.1) }\end{array}$ \\
\hline & Gantry Carrier & N/A & Non-SC & $\begin{array}{l}\text { Not applicable. No function of this SSC is credited for the prevention or mitigation of an } \\
\text { event sequence. }\end{array}$ \\
\hline \multicolumn{5}{|c|}{ Environmental/Meteorological Monitoring System } \\
\hline $\begin{array}{l}\text { Environmental/ } \\
\text { Meteorological } \\
\text { Monitoring }\end{array}$ & Entire & N/A & Non-SC & $\begin{array}{l}\text { Not applicable. None of the SSC functions associated with this subsystem are credited for } \\
\text { the prevention or mitigation of an event sequence. }\end{array}$ \\
\hline \multicolumn{5}{|r|}{ Fire Protection System } \\
\hline Fire Protection & Entire & N/A & Non-SC & $\begin{array}{l}\text { Not applicable. None of the SSC functions associated with these subsystems are credited } \\
\text { for the prevention or mitigation of an event sequence. }\end{array}$ \\
\hline \multicolumn{5}{|c|}{ HVAC Plant Heating and Cooling System } \\
\hline $\begin{array}{l}\text { HVAC Plant } \\
\text { Heating and } \\
\text { Cooling }\end{array}$ & Entire & N/A & Non-SC & $\begin{array}{l}\text { Not applicable. None of the SSC functions associated with these subsystems are credited } \\
\text { for the prevention or mitigation of an event sequence. }\end{array}$ \\
\hline
\end{tabular}




\begin{tabular}{|c|c|c|c|c|}
\hline $\begin{array}{l}\text { System or } \\
\text { Subsystem }\end{array}$ & $\begin{array}{l}\text { Component } \\
\text { or Function }\end{array}$ & $\begin{array}{l}\text { ITS or } \\
\text { ITWI }\end{array}$ & $\begin{array}{l}\text { Safety } \\
\text { Category }\end{array}$ & Nuclear Safety Design Bases \\
\hline \multicolumn{5}{|c|}{ Low-Level Radiological Waste Management System } \\
\hline $\begin{array}{l}\text { Low-Level } \\
\text { Radiological } \\
\text { Waste } \\
\text { Management }\end{array}$ & Entire & N/A & Non-SC & $\begin{array}{l}\text { Not applicable. None of the SSC functions associated with these subsystems are credited } \\
\text { for the prevention or mitigation of an event sequence. }\end{array}$ \\
\hline \multicolumn{5}{|c|}{ Low-Level Radiological Waste Generating Systems } \\
\hline $\begin{array}{l}\text { Low-Level } \\
\text { Radiological } \\
\text { Waste Generating }\end{array}$ & Entire & N/A & Non-SC & $\begin{array}{l}\text { Not applicable. None of the SSC functions associated with these subsystems are credited } \\
\text { for the prevention or mitigation of an event sequence. }\end{array}$ \\
\hline \multicolumn{5}{|c|}{ Naval Spent Nuclear Fuel Canister } \\
\hline $\begin{array}{l}\text { Naval SNF } \\
\text { Canister Internals }\end{array}$ & $\begin{array}{l}\text { Naval SNF } \\
\text { Canister Baskets, } \\
\text { Loading Sleeves } \\
\text { and Cans; Control } \\
\text { Rods or Neutron- } \\
\text { Absorbing } \\
\text { Material, } \\
\text { Attachment } \\
\text { Hardware; SNF } \\
\text { Cladding }\end{array}$ & ITWI & $\mathrm{SC}$ & $\begin{array}{l}\text { This SSC is ITWI; no function of this SSC is credited for the prevention or mitigation of an } \\
\text { event sequence. }\end{array}$ \\
\hline $\begin{array}{l}\text { Naval SNF } \\
\text { Canister }\end{array}$ & $\begin{array}{l}\text { Naval SNF } \\
\text { Canister }\end{array}$ & $\begin{array}{l}\text { ITS } \\
\text { ITWI }\end{array}$ & $\mathrm{SC}$ & $\begin{array}{l}\text { - The naval SNF canister shall not breach as a result of the credible fire }{ }^{5,7} \text {. } \\
\text { - The naval SNF canister shall be designed for loading conditions associated with a } \\
\text { DBGM-2 seismic event and to demonstrate sufficient seismic design margin to ensure that } \\
\text { a "no breach" safety function }{ }^{3} \text { is maintained for loading conditions associated with a } \\
\text { BDBGM seismic event. (BSC 2004a Table IV-1) }\end{array}$ \\
\hline
\end{tabular}




\begin{tabular}{|c|c|c|c|c|}
\hline $\begin{array}{l}\text { System or } \\
\text { Subsystem }\end{array}$ & $\begin{array}{l}\text { Component } \\
\text { or Function }\end{array}$ & $\begin{array}{l}\text { ITS or } \\
\text { ITWI }\end{array}$ & $\begin{array}{l}\text { Safety } \\
\text { Category }\end{array}$ & Nuclear Safety Design Bases \\
\hline \multicolumn{5}{|c|}{ Naval Spent Nuclear Fuel Waste Package System } \\
\hline Naval SNF WP & Entire & \begin{tabular}{|l} 
ITS \\
ITWI
\end{tabular} & SC & $\begin{array}{l}\text { - Sealed naval SNF WPs shall withstand without breaching the following drops: (BSC } \\
\text { 2005b Section 5.1.3.12) } \\
\text { A. Free-drop of } 6.5 \mathrm{ft}(3.3 \mathrm{ft} \text { for the naval long SNF WP) from a vertical orientation onto } \\
\text { a horizontal surface (trunnion collars installed) } \\
\text { B. Free-drop of } 7.8 \mathrm{ft} \text { from a horizontal orientation onto a horizontal surface (trunnion } \\
\text { collars installed) } \\
\text { C. Free-drop with the emplacement pallet from a horizontal orientation onto a horizontal } \\
\text { surface (trunnion collars not installed) of } 6.5 \mathrm{ft} \text { from the bottom of the emplacement } \\
\text { pallet } \\
\text { D. Tip-over onto a horizontal surface from a } 6.5 \mathrm{ft} \text { (1.6 ft for the naval long SNF WP) } \\
\text { elevated surface (trunnion collars installed) } \\
\text { E. Tip-over onto the tilting machine, including contact with the trunnion cradles or the } \\
\text { floor (trunnion collars installed). } \\
\text { Note: Drop and tip-over event sequences shall be evaluated for worst possible (most } \\
\text { damaging) credible conditions including initial geometric position and weight of } \\
\text { contents. An unyielding, flat horizontal surface may be used to bound the } \\
\text { consequences of a drop. Drops shall include attendant swing-down and/or slap- } \\
\text { down from the indicated position, with or without trunnion collars attached, as } \\
\text { appropriate. } \\
\text { - A naval SNF WP in a horizontal orientation on the emplacement pallet shall be lifted in } \\
\text { accordance with the lift height limits in Table C-1 in Appendix C. } \\
\text { - A naval long SNF WP in a vertical orientation shall be lifted in accordance with the lift } \\
\text { height limits in Table C-1 in Appendix C. } \\
\text { - Naval SNF WPs shall withstand a single rockfall of } 1.2 \times 10^{5} \text { joules or less without } \\
\text { breaching. (BSC } 2005 \mathrm{~b} \text { Section } 6.3 .6 .1 .20 \text { ) }\end{array}$ \\
\hline
\end{tabular}




\begin{tabular}{|c|c|c|c|c|}
\hline $\begin{array}{l}\text { System or } \\
\text { Subsystem }\end{array}$ & $\begin{array}{l}\text { Component } \\
\text { or Function }\end{array}$ & $\begin{array}{l}\text { ITS or } \\
\text { ITWI }\end{array}$ & $\begin{array}{l}\text { Safety } \\
\text { Category }\end{array}$ & Nuclear Safety Design Bases \\
\hline $\begin{array}{l}\text { Naval SNF WP } \\
\text { (continued) }\end{array}$ & Entire (continued) & $\begin{array}{l}\text { ITS } \\
\text { ITWI }\end{array}$ & SC & 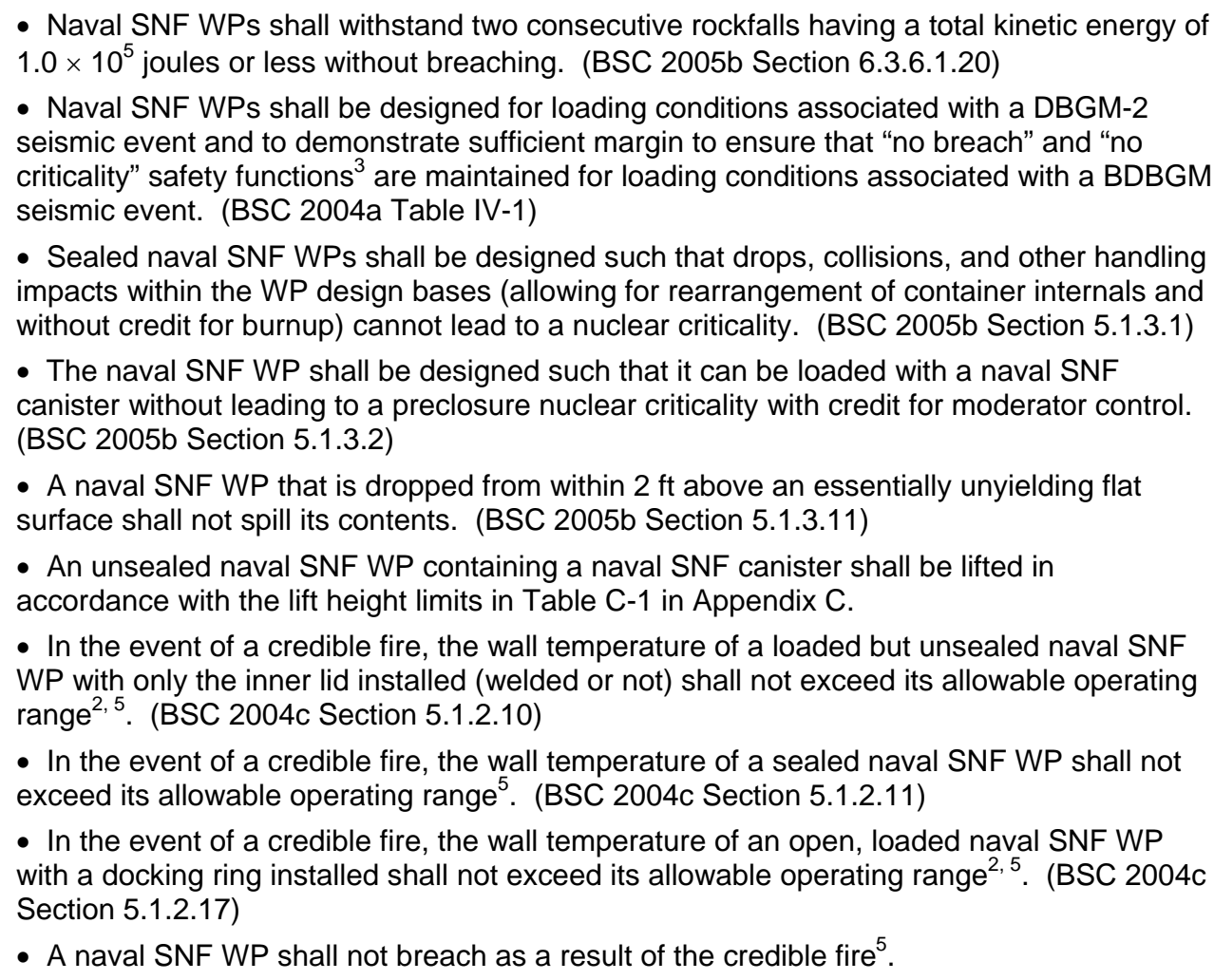 \\
\hline & Trunnion Collar & ITS & SC & $\begin{array}{l}\text { - Trunnion collars shall be designed for loading conditions associated with a DBGM-2 } \\
\text { seismic event and to demonstrate sufficient seismic design margin to ensure that a "no } \\
\text { drop" safety function }{ }^{3} \text { is maintained for loading conditions associated with a BDBGM } \\
\text { seismic event. (BSC 2004a Table IV-1) }\end{array}$ \\
\hline
\end{tabular}




\begin{tabular}{|c|c|c|c|c|}
\hline $\begin{array}{l}\text { System or } \\
\text { Subsystem }\end{array}$ & $\begin{array}{l}\text { Component } \\
\text { or Function }\end{array}$ & $\begin{array}{l}\text { ITS or } \\
\text { ITWI }\end{array}$ & $\begin{array}{l}\text { Safety } \\
\text { Category }\end{array}$ & Nuclear Safety Design Bases \\
\hline \multicolumn{5}{|c|}{ Non-Nuclear Handling System } \\
\hline $\begin{array}{l}\text { Non-Nuclear } \\
\text { Handling }\end{array}$ & Entire & N/A & Non-SC & $\begin{array}{l}\text { Not applicable. None the SSC functions associated with these subsystems are credited for } \\
\text { the prevention or mitigation of an event sequence. }\end{array}$ \\
\hline \multicolumn{5}{|c|}{ Non-Radiological Waste Management System } \\
\hline $\begin{array}{l}\text { Non-Radiological } \\
\text { Waste } \\
\text { Management }\end{array}$ & Entire & N/A & Non-SC & $\begin{array}{l}\text { Not applicable. None of the SSC functions associated with these subsystems are credited } \\
\text { for the prevention or mitigation of an event sequence. }\end{array}$ \\
\hline \multicolumn{5}{|r|}{ Plant Services System } \\
\hline Plant Services & Entire & N/A & Non-SC & $\begin{array}{l}\text { Not applicable. None of the SSC functions associated with these subsystems are credited } \\
\text { for the prevention or mitigation of an event sequence. }\end{array}$ \\
\hline \multicolumn{5}{|c|}{ Radiation/Radiological Monitoring System } \\
\hline $\begin{array}{l}\text { Radiation/ } \\
\text { Radiological } \\
\text { Monitoring }\end{array}$ & Entire & N/A & Non-SC & $\begin{array}{l}\text { Not applicable. None of the SSC functions associated with these subsystems are credited } \\
\text { for the prevention or mitigation of an event sequence. }\end{array}$ \\
\hline \multicolumn{5}{|r|}{ Remediation System } \\
\hline Dry Remediation & $\begin{array}{l}\text { Trolley, Pedestal, } \\
\text { and Hold-Down } \\
\text { Device }\end{array}$ & ITS & SC & $\begin{array}{l}\text { - Upon a loss of power, this trolley shall be designed to stop, retain its load, and enter a } \\
\text { locked mode; upon a restoration of power, this trolley shall stay in the locked mode until } \\
\text { operator action is taken. (BSC 2005b Section 5.1.2.2) }\end{array}$ \\
\hline
\end{tabular}


Table A-II. Nuclear Safety Design Bases of Systems and Subsystems

\begin{tabular}{|c|c|c|c|c|}
\hline $\begin{array}{l}\text { System or } \\
\text { Subsystem }\end{array}$ & $\begin{array}{l}\text { Component } \\
\text { or Function }\end{array}$ & $\begin{array}{l}\text { ITS or } \\
\text { ITWI }\end{array}$ & $\begin{array}{l}\text { Safety } \\
\text { Category }\end{array}$ & Nuclear Safety Design Bases \\
\hline $\begin{array}{l}\text { Dry Remediation } \\
\text { (continued) }\end{array}$ & $\begin{array}{l}\text { Trolley, Pedestal, } \\
\text { and Hold-Down } \\
\text { Device } \\
\text { (continued) }\end{array}$ & ITS & SC & $\begin{array}{l}\text { - Pedestals and hold-down devices shall be designed for loading conditions associated } \\
\text { with a DBGM-2 seismic event and to demonstrate sufficient seismic design margin to } \\
\text { ensure that a "no tipover" safety function }{ }^{3} \text { is maintained for loading conditions associated } \\
\text { with a BDBGM seismic event. (BSC } 2004 a \text { Table IV-1) } \\
\text { - The trolley system shall be designed for loading conditions associated with a DBGM-2 } \\
\text { seismic event to maintain trolley stability and prevent waste container slapdown. In } \\
\text { addition, an analysis shall demonstrate that the trolley system has sufficient seismic design } \\
\text { margin to ensure that a "no slapdown" safety function is maintained for loading conditions } \\
\text { associated with a BDBGM seismic event. (BSC } 2004 a \text { Table IV-1) } \\
\text { - The trolley shall be designed with an inherent speed limit such that a collision at the } \\
\text { trolley speed limit would not cause the trolley to drop its load. (BSC 2005b Section } \\
5.1 .1 .61 \text { ) } \\
\text { - Loaded transfer trolleys shall not derail or drop their loads. (BSC 2005b Section } \\
5.1 .1 .36 \text { ) } \\
\text { - In the event of a credible fire in an area where waste forms are present, the temperature } \\
\text { of the machinery that handles or transports SNF/HLW shall not reach a level that would } \\
\text { make it drop its load. (BSC 2004c Section } 5.1 .3 .1 \text { ) } \\
\text { - A tipover and breach of a cask while on machinery that handles or transports SNF/HLW } \\
\text { due to uncontrolled movements produced by a loss of power or a spurious signal caused } \\
\text { by a fire shall have a probability of less than } 1 \times 10^{-4} \text { over the life of the facility. (BSC } \\
2004 c \text { Section 5.1.3.4; BSC } 2005 b \text { Section } 6.1 .1 .1 \text { ) }\end{array}$ \\
\hline & Turntable & ITS & SC & $\begin{array}{l}\text { - The turntable system shall be designed for loading conditions associated with a DBGM-2 } \\
\text { seismic event to maintain turntable stability and prevent waste container tipover. In } \\
\text { addition, an analysis shall demonstrate that the turntable system has sufficient seismic } \\
\text { design margin to ensure that a "no tipover" safety function }{ }^{3} \text { is maintained for loading } \\
\text { conditions associated with a BDBGM seismic event. (BSC 2004a Table IV-1) }\end{array}$ \\
\hline
\end{tabular}




\begin{tabular}{|c|c|c|c|c|}
\hline $\begin{array}{l}\text { System or } \\
\text { Subsystem }\end{array}$ & $\begin{array}{l}\text { Component } \\
\text { or Function }\end{array}$ & $\begin{array}{l}\text { ITS or } \\
\text { ITWI }\end{array}$ & $\begin{array}{l}\text { Safety } \\
\text { Category }\end{array}$ & Nuclear Safety Design Bases \\
\hline $\begin{array}{l}\text { Dry Remediation } \\
\text { (continued) }\end{array}$ & $\begin{array}{l}\text { Turntable } \\
\text { (continued) }\end{array}$ & ITS & SC & $\begin{array}{l}\text { - In the event of a credible fire in an area where waste forms are present, the temperature } \\
\text { of machinery that handles or transports SNF/HLW shall not reach a level that would cause } \\
\text { a drop of a cask or a WP while on the turntable. (BSC } 2004 \mathrm{c} \text { Section } 5.1 .3 .1 \text { ) } \\
\text { - A tipover and breach of a cask while on a turntable that handles SNF/HLW due to } \\
\text { uncontrolled movements produced by a loss of power or a spurious signal caused by a fire } \\
\text { shall have a probability of less than } 1 \times 10^{-4} \text { over the life of the facility. (BSC } 2004 \mathrm{c} \\
\text { Section 5.1.3.4; BSC } 2005 \mathrm{~b} \text { Section 6.1.1.1) }\end{array}$ \\
\hline & Docking Station & ITS & SC & $\begin{array}{l}\text { - A drop or collision involving components associated with a docking port shall not breach } \\
\text { the lid of a transportation cask or site-specific cask situated at the docking port. (BSC } \\
2005 \text { b Section 5.1.1.17) }\end{array}$ \\
\hline Wet Remediation & $\begin{array}{l}\text { Cask Handling } \\
\text { Crane; } \\
200 \text { ton }\end{array}$ & ITS & SC & $\begin{array}{l}\text { - The drop rate for cranes involved in handling waste forms and their associated } \\
\text { containers shall be less than or equal to } 1 \times 10^{-5} \text { drops/transfer, regardless of cause, } \\
\text { including human error, failure of equipment such as yokes and grapples, or a combination } \\
\text { of the two. (BSC 2005b Section } 5.1 .1 .10 \text { ) } \\
\text { - Upon a loss of power, this crane shall be designed to stop, retain its load, and enter a } \\
\text { locked mode; upon a restoration of power, this crane shall stay in the locked mode until } \\
\text { operator action is taken. (BSC } 2005 \mathrm{~b} \text { Section } 5.1 .2 .1 \text { ) } \\
\text { - The conditional probability of the crane exceeding a lift-height limit, given that a drop has } \\
\text { occurred, shall be less than or equal to } 1 \times 10^{-4} \text {. (BSC } 2005 \mathrm{~b} \text { Section } 5.1 .1 .12 \text { ) } \\
\text { - The lift height limit for transportation casks without impact limiters or site-specific } \\
\text { casks is provided in Table C-1 of Appendix C. } \\
\text { - This crane and its rigging shall be designed for loading conditions associated with a } \\
\text { DBGM-2 seismic event and to demonstrate sufficient seismic design margin to ensure that } \\
\text { a "no drop" safety function is maintained for loading conditions associated with a BDBGM } \\
\text { seismic event. (BSC } 2004 a \text { Table IV-1) } \\
\text { - This crane shall not be capable of moving above a speed limit for overhead crane } \\
\text { transfers such that a collision at the speed limit would not breach a transportation cask or } \\
\text { site-specific cask. (BSC 2005b Section 5.1.1.19) }\end{array}$ \\
\hline
\end{tabular}




\begin{tabular}{|c|c|c|c|c|}
\hline $\begin{array}{l}\text { System or } \\
\text { Subsystem }\end{array}$ & $\begin{array}{l}\text { Component } \\
\text { or Function }\end{array}$ & $\begin{array}{l}\text { ITS or } \\
\text { ITWI }\end{array}$ & $\begin{array}{l}\text { Safety } \\
\text { Category }\end{array}$ & Nuclear Safety Design Bases \\
\hline \multirow[t]{5}{*}{$\begin{array}{l}\text { Wet Remediation } \\
\text { (continued) }\end{array}$} & $\begin{array}{l}\text { Cask Handling } \\
\text { Crane; } \\
200 \text { ton } \\
\text { (continued) }\end{array}$ & ITS & SC & $\begin{array}{l}\text { - This crane shall not be capable of exerting sufficient force during transfer to breach a } \\
\text { cask as the result of attempts to overcome mechanical constraints. (BSC } 2005 \mathrm{~b} \text { Section } \\
5.1 .1 .20 \text { ) } \\
\text { - In the event of a credible fire in an area where waste forms are present, the temperature } \\
\text { of the crane that handles or transports SNF/HLW shall not reach a level that would make it } \\
\text { drop its load. (BSC } 2004 \mathrm{c} \text { Section } 5.1 .3 .1 \text { ) } \\
\text { - A drop of a load from a crane that handles SNF/HLW due to a spurious signal caused by } \\
\text { a fire shall have a probability of less than } 1 \times 10^{-4} \text { over the life of the facility. (BSC } 2004 \mathrm{C} \\
\text { Section 5.1.3.4; BSC } 2005 \mathrm{~b} \text { Section } 6.1 .1 .1 \text { ) }\end{array}$ \\
\hline & Pit Crush Pad & ITS & SC & $\begin{array}{l}\text { - Crush pads shall limit the impact energy of a dropped canister, cask, or WP to be less } \\
\text { than or equal to the impact energy associated with a drop of a cask or WP onto an } \\
\text { unyielding surface from their maximum specified drop height for the cask or WP'. (BSC } \\
2005 \text { b Section 5.1.1.18) }\end{array}$ \\
\hline & Pool Crush Pad & ITS & SC & $\begin{array}{l}\text { - The remediation pool shall be designed with the appropriate impact-absorbing capability } \\
\text { to prevent loss of pool integrity given a drop of the most challenging transportation cask or } \\
\text { site-specific cask into the pool. (BSC 2005b Section 5.1.2.6) }\end{array}$ \\
\hline & Turntable & N/A & Non-SC & $\begin{array}{l}\text { Not applicable. No function of this SSC is credited for the prevention or mitigation of an } \\
\text { event sequence. }\end{array}$ \\
\hline & $\begin{array}{l}\text { Fuel Handling } \\
\text { Machine and } \\
\text { Grapples }\end{array}$ & ITS & SC & $\begin{array}{l}\text { - The fuel handling machine and grapples shall be designed for loading conditions } \\
\text { associated with a DBGM-1 seismic event and demonstrate sufficient seismic design } \\
\text { margin to a "maintain waste form" safety function }{ }^{3} \text {. (BSC } 2004 \text { a Table IV-1) } \\
\text { - The fuel handling machine and grapples shall be designed for loading conditions } \\
\text { associated with a DBGM-2 seismic event and to demonstrate sufficient seismic design } \\
\text { margin to ensure that a "no fall down" safety function }{ }^{3} \text { is maintained for loading conditions } \\
\text { associated with a BDBGM seismic event. (BSC } 2004 a \text { Table IV-1) } \\
\text { - The fuel handling machine shall have a drop rate of less than or equal to } 1 \times 10^{-5} \\
\text { drops/transfer, including transfers in single-assembly canisters. (BSC } 2005 \mathrm{~b} \text { Section } \\
\text { 5.1.1.7) }\end{array}$ \\
\hline
\end{tabular}


Table A-II. Nuclear Safety Design Bases of Systems and Subsystems

\begin{tabular}{|c|c|c|c|c|}
\hline $\begin{array}{l}\text { System or } \\
\text { Subsystem }\end{array}$ & $\begin{array}{l}\text { Component } \\
\text { or Function }\end{array}$ & $\begin{array}{l}\text { ITS or } \\
\text { ITWI }\end{array}$ & $\begin{array}{l}\text { Safety } \\
\text { Category }\end{array}$ & Nuclear Safety Design Bases \\
\hline \multirow[t]{3}{*}{$\begin{array}{l}\text { Wet Remediation } \\
\text { (continued) }\end{array}$} & $\begin{array}{l}\text { Fuel Handling } \\
\text { Machine and } \\
\text { Grapples } \\
\text { (continued) }\end{array}$ & $\begin{array}{l}\text { ITS } \\
1\end{array}$ & SC & $\begin{array}{l}\text { - The rate of collisions during an assembly transfer operation shall be less than or equal to } \\
1 \times 10^{-5} \text { collisions/transfer. (BSC } 2005 \text { b Section } 5.1 .1 .8 \text { ) } \\
\text { - The probability of a drop of handling equipment onto a commercial SNF assembly with } \\
\text { enough energy to breach the assembly shall be less than or equal to } 1 \times 10^{-7} \\
\text { impacts/transfer for each assembly transferred. (BSC } 2005 \text { b Section } 5.1 .1 .9 \text { ) } \\
\text { - The fuel handling machine shall not be capable of lateral movements of handling } \\
\text { equipment at a speed that could initiate an event sequence as a result of a collision with an } \\
\text { SNF assembly. (BSC } 2005 b \text { Section } 5.1 .1 .54 \text { ) } \\
\text { - Upon a loss of power, the fuel handling machine shall be designed to stop, retain its } \\
\text { load, and enter a locked mode; upon a restoration of power, this crane shall stay in the } \\
\text { locked mode until operator action is taken. (BSC } 2005 \text { b Section } 5.1 .2 .1 \text { ) } \\
\text { - In the event of a credible fire in an area where waste forms are present, the temperature } \\
\text { of the machinery that handles or transports SNF/HLW shall not reach a level that would } \\
\text { make it drop its load. (BSC } 2004 \mathrm{c} \text { Section } 5.1 .3 .1 \text { ) } \\
\text { - A drop of a load from machinery that handles SNF due to a spurious signal caused by a } \\
\text { fire shall have a probability of less than } 1 \times 10^{-4} \text { over the life of the facility. (BSC } 2004 \mathrm{c} \\
\text { Section 5.1.3.4; BSC } 2005 \mathrm{~b} \text { Section } 6.1 .1 .1 \text { ) }\end{array}$ \\
\hline & $\begin{array}{l}\text { Crane Lifting } \\
\text { Yokes and } \\
\text { Grapples }\end{array}$ & ITS & SC & $\begin{array}{l}\text { - The crane lifting yokes and grapples shall be designed for loading conditions associated } \\
\text { with a DBGM-2 seismic event. In addition, an analysis shall demonstrate that the crane } \\
\text { lifting yokes and grapples have sufficient seismic design margin to ensure that a "no drop" } \\
\text { safety function }{ }^{3} \text { is maintained for loading conditions associated with a BDBGM seismic } \\
\text { event. (BSC 2004a Table IV-1) }\end{array}$ \\
\hline & $\begin{array}{l}\text { Staging } \\
\text { Racks/Baskets in } \\
\text { Remediation Pool }\end{array}$ & ITS & SC & $\begin{array}{l}\text { - The staging racks shall be designed for loading conditions associated with a DBGM-2 } \\
\text { seismic event for stability and distortion such as to maintain assembly geometry in the } \\
\text { rack. In addition, analyses shall demonstrate that the staging racks have sufficient seismic } \\
\text { design margin to ensure that distortion of the racks is limited and stability is maintained for } \\
\text { loading conditions associated with a BDBGM seismic event. (BSC 2004a Table IV-1) }\end{array}$ \\
\hline
\end{tabular}




\begin{tabular}{|c|c|c|c|c|}
\hline $\begin{array}{l}\text { System or } \\
\text { Subsystem }\end{array}$ & $\begin{array}{l}\text { Component } \\
\text { or Function }\end{array}$ & $\begin{array}{l}\text { ITS or } \\
\text { ITWI }\end{array}$ & $\begin{array}{l}\text { Safety } \\
\text { Category }\end{array}$ & Nuclear Safety Design Bases \\
\hline $\begin{array}{l}\text { Wet Remediation } \\
\text { (continued) }\end{array}$ & \begin{tabular}{|l} 
Staging \\
Racks/Baskets in \\
Remediation Pool \\
(continued)
\end{tabular} & ITS & SC & $\begin{array}{l}\text { - Fully loaded baskets in staging racks shall be subcritical when fully flooded with pure } \\
\text { water (i.e., no credit for neutron absorbers dissolved in the water); the baskets shall have } \\
\text { sufficient criticality controls to remain subcritical under the expected range of conditions } \\
\text { resulting from handling incidents in and out of staging racks; and the baskets shall be } \\
\text { closed during handling such that a closed basket being transferred in the pool will not spill } \\
\text { SNF assemblies into the pool if the basket is dropped. (BSC 2005b Section 5.1.5.9) }\end{array}$ \\
\hline WP Remediation & $\begin{array}{l}\text { WP Remediation } \\
\text { Crane; } 100 \text { ton }\end{array}$ & ITS & SC & $\begin{array}{l}\text { - The drop rate for cranes involved in handling waste forms and their associated } \\
\text { containers shall be less than or equal to } 1 \times 10^{-5} \text { drops/transfer, regardless of cause, } \\
\text { including human error, failure of equipment such as yokes and grapples, or a combination } \\
\text { of the two. (BSC 2005b Section } 5.1 .1 .10 \text { ) } \\
\text { - The probability of dropping handling equipment from a crane onto a canister shall be } \\
\text { less than or equal to } 1 \times 10^{-5} \text { for each canister transferred. (BSC } 2005 \mathrm{~b} \text { Section } 5.1 .1 .11 \text { ) } \\
\text { - Upon a loss of power, this crane shall be designed to stop, retain its load, and enter a } \\
\text { locked mode; upon a restoration of power, this crane shall stay in the locked mode until } \\
\text { operator action is taken. (BSC } 2005 \mathrm{~b} \text { Section } 5.1 .2 .1 \text { ) } \\
\text { - The conditional probability of the crane exceeding a lift-height limit, given that a drop has } \\
\text { occurred, shall be less than or equal to } 1 \times 10^{-4} \text {. (BSC 2005b Section 5.1.1.12) } \\
\text { - The lift height limits for the WPs and canisters handled by this crane are provided in } \\
\text { Table C-1 in Appendix C; these WPs and canisters include: } \\
\text { 1. Sealed WPs containing commercial SNF, standardized DOE canisters, DOE HLW } \\
\text { canisters, naval SNF canisters, or DOE MCOs. } \\
\text { 2. Unsealed, loaded WPs containing commercial SNF, standardized DOE canisters, } \\
\text { DOE HLW canisters, naval SNF canisters, or DOE MCOs. } \\
\text { 3. Standardized DOE SNF canisters, DOE HLW canisters, DOE MCOs, sealed } \\
\text { vertical DPCs, or unsealed vertical DPCs. } \\
\text { - This crane system shall be designed for loading conditions associated with a DBGM-2 } \\
\text { seismic event and maintain its load. In addition, an analysis shall demonstrate that this } \\
\text { crane system has sufficient seismic design margin to ensure that a "no drop" safety } \\
\text { function }{ }^{3} \text { is maintained for loading conditions associated with a BDBGM seismic event. } \\
\text { (BSC 2004a Table IV-1) }\end{array}$ \\
\hline
\end{tabular}


Table A-II. Nuclear Safety Design Bases of Systems and Subsystems

\begin{tabular}{|c|c|c|c|c|}
\hline $\begin{array}{l}\text { System or } \\
\text { Subsystem }\end{array}$ & $\begin{array}{l}\text { Component } \\
\text { or Function }\end{array}$ & $\begin{array}{l}\text { ITS or } \\
\text { ITWI }\end{array}$ & $\begin{array}{l}\text { Safety } \\
\text { Category }\end{array}$ & Nuclear Safety Design Bases \\
\hline \multirow[t]{3}{*}{$\begin{array}{l}\text { WP Remediation } \\
\text { (continued) }\end{array}$} & $\begin{array}{l}\text { WP Remediation } \\
\text { Crane;100 ton } \\
\text { (continued) }\end{array}$ & ITS & SC & $\begin{array}{l}\text { - This crane shall not be capable of moving above a speed limit for overhead crane } \\
\text { transfers such that a collision at the speed limit would not breach a loaded sealed WP, a } \\
\text { DOE MCO, a standardized DOE SNF canister, a DOE HLW canister, or a DPC. (BSC } \\
2005 \mathrm{~b} \text { Section 5.1.1.19) } \\
\text { - This crane shall not be capable of exerting sufficient force to breach a WP or a canister } \\
\text { as the result of attempts to overcome mechanical constraints. (BSC 2005b Section } \\
5.1 .1 .20 \text { ) } \\
\text { - This crane, which can be used to transfer SNF assemblies, shall not be capable of } \\
\text { lateral movements of handling equipment at a speed that could initiate an event sequence } \\
\text { as a result of a collision with an SNF assembly. (BSC } 2005 \mathrm{~b} \text { Section } 5.1 .1 .54 \text { ) } \\
\text { - In the event of a credible fire in an area where waste forms are present, the temperature } \\
\text { of the crane that handles or transports SNF/HLW shall not reach a level that would make it } \\
\text { drop its load. (BSC 2004c Section 5.1.3.1) } \\
\text { - A drop of a load from a crane that handles SNF/HLW due to a spurious signal caused by } \\
\text { a fire shall have a probability of less than } 1 \times 10^{-4} \text { over the life of the facility. (BSC 2004c } \\
\text { Section 5.1.3.4; BSC 2005b Section } 6.1 .1 .1 \text { ) }\end{array}$ \\
\hline & $\begin{array}{l}\text { Crane Lifting } \\
\text { Yokes }\end{array}$ & ITS & SC & $\begin{array}{l}\text { - Crane lifting yokes shall be designed for loading conditions associated with a DBGM-2 } \\
\text { seismic event and to demonstrate sufficient seismic design margin to ensure that a "no } \\
\text { drop" safety function }{ }^{3} \text { is maintained for loading conditions associated with a BDBGM } \\
\text { seismic event. (BSC 2004a Table IV-1) }\end{array}$ \\
\hline & $\begin{array}{l}\text { WP/DPC Trolley, } \\
\text { Pedestal, and } \\
\text { Hold-Down } \\
\text { Devices }\end{array}$ & ITS & SC & $\begin{array}{l}\text { - Upon a loss of power, this trolley shall be designed to stop, retain its load, and enter a } \\
\text { locked mode; upon a restoration of power, this trolley shall stay in the locked mode until } \\
\text { operator action is taken. (BSC 2005b Section 5.1.2.2) } \\
\text { - The trolley system shall be designed for loading conditions associated with a DBGM-2 } \\
\text { seismic event to maintain trolley stability and prevent waste container slapdown. In } \\
\text { addition, an analysis shall demonstrate that the trolley system has sufficient seismic design } \\
\text { margin to ensure that a "no slapdown" safety function is maintained for loading conditions } \\
\text { associated with a BDBGM seismic event. (BSC 2004a Table IV-1) }\end{array}$ \\
\hline
\end{tabular}




\begin{tabular}{|c|c|c|c|c|}
\hline $\begin{array}{l}\text { System or } \\
\text { Subsystem }\end{array}$ & $\begin{array}{l}\text { Component } \\
\text { or Function }\end{array}$ & $\begin{array}{l}\text { ITS or } \\
\text { ITWI }\end{array}$ & $\begin{array}{l}\text { Safety } \\
\text { Category }\end{array}$ & Nuclear Safety Design Bases \\
\hline $\begin{array}{l}\text { WP Remediation } \\
\text { (continued) }\end{array}$ & $\begin{array}{l}\text { WP/DPC Trolley, } \\
\text { Pedestal, and } \\
\text { Hold-Down } \\
\text { Devices } \\
\text { (continued) }\end{array}$ & ITS & sc & $\begin{array}{l}\text { - Pedestals and hold-down devices shall be designed for loading conditions associated } \\
\text { with a DBGM-2 seismic event and to demonstrate sufficient seismic design margin to } \\
\text { ensure that a "no tipover" safety function is maintained for loading conditions associated } \\
\text { with a BDBGM seismic event. (BSC } 2004 \text { a Table IV-1) } \\
\text { - The trolley shall be designed with an inherent speed limit such that a collision at the } \\
\text { trolley speed limit would not cause the trolley to drop its load. (BSC } 2005 \mathrm{~b} \text { Section } \\
5.1 .1 .61 \text { ) } \\
\text { - Loaded transfer trolleys shall not derail or drop their loads. (BSC } 2005 \mathrm{~b} \text { Section } \\
\text { 5.1.1.36) } \\
\text { - In the event of a credible fire in an area where waste forms are present, the temperature } \\
\text { of the machinery that handles or transports SNF/HLW shall not reach a level that would } \\
\text { make it drop its load. (BSC } 2004 \mathrm{c} \text { Section } 5.1 .3 .1 \text { ) } \\
\text { - A tipover and breach of a cask while on machinery that transports SNF/HLW due to } \\
\text { uncontrolled movements produced by a loss of power or a spurious signal caused by a fire } \\
\text { shall have a probability of less than } 1 \times 10^{-4} \text { over the life of the facility. (BSC } 2004 \mathrm{c} \\
\text { Section 5.1.3.4; BSC } 2005 \mathrm{~b} \text { Section } 6.1 .1 .1 \text { ) }\end{array}$ \\
\hline \multicolumn{5}{|c|}{ Safeguards and Security System } \\
\hline $\begin{array}{l}\text { Safeguards and } \\
\text { Security }\end{array}$ & Entire & N/A & Non-SC & $\begin{array}{l}\text { Not applicable. None of the SSC functions associated with these subsystems are credited } \\
\text { for the prevention or mitigation of an event sequence. }\end{array}$ \\
\hline \multicolumn{5}{|r|}{ SNF Aging } \\
\hline Cask Transfer & Cask Tractor & ITS & SC & $\begin{array}{l}\text { - The design of the horizontal cask transfer trailer tractor shall limit the potential damage } \\
\text { caused by collisions. (Cogema } 2004 \text { No. S.23 Table 6-6) } \\
\text { - Loss of power events shall be precluded. (Cogema } 2004 \text { No. S.4 Table 6-6) } \\
\text { - Tip-over during transfer shall be precluded by ensuring that minimum tip-over } \\
\text { resistance/standards are maintained consistent with roadway design. (Cogema } 2004 \text { No. } \\
\text { S.25 Table 6-6) }\end{array}$ \\
\hline
\end{tabular}


Table A-II. Nuclear Safety Design Bases of Systems and Subsystems

\begin{tabular}{|c|c|c|c|c|}
\hline $\begin{array}{l}\text { System or } \\
\text { Subsystem }\end{array}$ & $\begin{array}{l}\text { Component } \\
\text { or Function }\end{array}$ & $\begin{array}{l}\text { ITS or } \\
\text { ITWI }\end{array}$ & $\begin{array}{l}\text { Safety } \\
\text { Category }\end{array}$ & Nuclear Safety Design Bases \\
\hline \multirow[t]{2}{*}{$\begin{array}{l}\text { Cask Transfer } \\
\text { (continued) }\end{array}$} & $\begin{array}{l}\text { Cask Tractor } \\
\text { (continued) }\end{array}$ & ITS & SC & $\begin{array}{l}\text { - The design of the horizontal cask transfer trailer tractor shall provide reliable means to } \\
\text { stop and maintain stability. (Cogema } 2004 \text { No. S.26 Table 6-6) } \\
\text { - The cask tractor system shall be designed to prevent runaway of the tractor under } \\
\text { loading conditions associated with a DBGM-2 seismic event. In addition, an analysis shall } \\
\text { demonstrate that the cask tractor system has sufficient seismic design margin to ensure } \\
\text { that a "no runaway" safety function is maintained for loading conditions associated with a } \\
\text { BDBGM seismic event. (BSC 2004a Table IV-1) }\end{array}$ \\
\hline & $\begin{array}{l}\text { Horizontal Cask } \\
\text { Transfer Trailer }\end{array}$ & ITS & SC & $\begin{array}{l}\text { - The design of the hydraulic ram shall ensure that it cannot fail or be operated in a } \\
\text { manner that can cause a DPC loss of function through excess force or ram over-travel. } \\
\text { (Cogema } 2004 \text { No. S.28 Table 6-6) } \\
\text { - The horizontal cask transfer trailer system shall be designed for stability and to retain the } \\
\text { waste container and prevent a runaway for loading conditions associated with a DBGM-2 } \\
\text { seismic event. In addition, an analysis shall demonstrate that the horizontal cask transfer } \\
\text { trailer has sufficient seismic design margin to ensure that "no slapdown" and "no runaway" } \\
\text { safety functions }{ }^{3} \text { are maintained for loading conditions associated with a BDBGM seismic } \\
\text { event. (BSC } 2004 \text { a Table IV-1) } \\
\text { - The design of the horizontal cask transfer trailer shall limit the maximum potential drop } \\
\text { height. (Cogema } 2004 \text { No. S.22 Table 6-6) } \\
\text { - The design of the horizontal cask transfer trailer/tractor shall limit potential damage to a } \\
\text { loaded SNF cask caused by collisions. (Cogema } 2004 \text { No. S.23 Table 6-6) } \\
\text { - The design of the horizontal cask transfer trailer shall preclude tip-over during transfer by } \\
\text { ensuring that the transfer equipment design precludes failure modes that could result in tip- } \\
\text { over under design basis load handling conditions and by ensuring that minimum tip-over } \\
\text { resistance/stability standards are maintained consistent with roadway design. (Cogema } \\
2004 \text { Nos. S.24 and S. 25Table 6-6) }\end{array}$ \\
\hline
\end{tabular}


Table A-II. Nuclear Safety Design Bases of Systems and Subsystems

\begin{tabular}{|c|c|c|c|c|}
\hline $\begin{array}{l}\text { System or } \\
\text { Subsystem }\end{array}$ & $\begin{array}{l}\text { Component } \\
\text { or Function }\end{array}$ & $\begin{array}{l}\text { ITS or } \\
\text { ITWI }\end{array}$ & $\begin{array}{l}\text { Safety } \\
\text { Category }\end{array}$ & Nuclear Safety Design Bases \\
\hline $\begin{array}{l}\text { Cask Transfer } \\
\text { (continued) }\end{array}$ & $\begin{array}{l}\text { Site-Specific Cask } \\
\text { Transporter }\end{array}$ & ITS & SC & $\begin{array}{l}\text { - The site-specific cask transporter system shall be designed for stability and to retain the } \\
\text { waste container and prevent a runaway for loading conditions associated with a DBGM-2 } \\
\text { seismic event. In addition, an analysis shall demonstrate that the site-specific cask } \\
\text { transporter system has sufficient seismic design margin to ensure that "no slapdown" and } \\
\text { "no runaway" safety functions } 3 \text { are maintained for loading conditions associated with a } \\
\text { BDBGM seismic event. (BSC } 2004 \text { a Table IV-1) } \\
\text { - A speed limit for the site-specific cask transporter shall be established such that a } \\
\text { collision with shield or airlock doors or other heavy objects does not overturn the site- } \\
\text { specific cask transporter or cause it to drop its load. (BSC 2005b Section 5.1.1.38) } \\
\text { - The cask transporter shall prevent the lifting of aging and transfer casks above their } \\
\text { maximum handling height. (BSC } 2005 \text { b Section } 4.1 .11 \text { ) } \\
\text { - The design of the site-specific cask transporter shall limit the maximum potential drop } \\
\text { height. (Cogema } 2004 \text { No. S.22 Table 6-6) } \\
\text { - The design of the site-specific cask transporter shall limit potential damage to a loaded } \\
\text { SNF cask caused by collisions. (Cogema } 2004 \text { No. S.23 Table 6-6) } \\
\text { - The design of the site-specific cask transporter shall preclude tip-over during transfer by } \\
\text { ensuring that the transfer equipment design precludes failure modes that could result in tip- } \\
\text { over under design basis load handling conditions and by ensuring that minimum tip-over } \\
\text { resistance/stability standards are maintained consistent with roadway design. (Cogema } \\
2004 \text { Nos. S.24 and } 25 \text { Table } 6-6 \text { ) } \\
\text { - The design of the site-specific cask transporter shall provide reliable means to stop and } \\
\text { maintain stability. (Cogema } 2004 \text { No. S.26 Table 6-6) } \\
\text { - Loss of power events shall be precluded. (Cogema 2004 No. S.4 Table 6-6) } \\
\text { - Upon a loss of power, this transporter shall be designed to stop, retain its load, and enter } \\
\text { a locked mode; upon a restoration of power, this transporter shall stay in the locked mode } \\
\text { until operator action is taken. (BSC } 2005 \text { b Section 5.1.2.2) }\end{array}$ \\
\hline
\end{tabular}




\begin{tabular}{|c|c|c|c|c|}
\hline $\begin{array}{l}\text { System or } \\
\text { Subsystem }\end{array}$ & $\begin{array}{l}\text { Component } \\
\text { or Function }\end{array}$ & $\begin{array}{l}\text { ITS or } \\
\text { ITWI }\end{array}$ & $\begin{array}{l}\text { Safety } \\
\text { Category }\end{array}$ & Nuclear Safety Design Bases \\
\hline $\begin{array}{l}\text { Cask Transfer } \\
\text { (continued) }\end{array}$ & $\begin{array}{l}\text { Site-Specific } \\
\text { Transfer Cask }\end{array}$ & ITS & SC & $\begin{array}{l}\text { - The design of the site-specific transfer casks shall ensure that they can withstand a drop } \\
\text { from the maximum handling height of a horizontal cask transfer trailer without loss of } \\
\text { function. (Cogema } 2004 \text { No. S.12 Table 6-6) } \\
\text { - The design of the site-specific transfer casks shall ensure that they can withstand a drop } \\
\text { of heavy objects handled during transfer operations; e.g., access cover plate, from the } \\
\text { maximum handling height without adverse effects. (Cogema } 2004 \text { No. S.14 Table 6-6) }\end{array}$ \\
\hline \multirow[t]{6}{*}{ Aging Pad } & $\begin{array}{l}\text { Surface Aging } \\
\text { Pad }\end{array}$ & ITS & SC & $\begin{array}{l}\text { - The aging pad shall be designed to preclude inundation during the maximum probable } \\
\text { flood. (Cogema } 2004 \text { No. S.20 Table 6-6) }\end{array}$ \\
\hline & & & & $\begin{array}{l}\text { - The aging pad shall be located to avoid placement directly over Quaternary faults with a } \\
\text { potential for significant displacement. (Cogema } 2004 \text { No. S.21 Table 6-6) }\end{array}$ \\
\hline & & & & $\begin{array}{l}\text { - The surface aging pad system shall be designed for loading conditions associated with a } \\
\text { DBGM-2 seismic event. In addition, an analysis shall demonstrate that the surface aging } \\
\text { pad system has sufficient seismic design margin to ensure that a "no significant } \\
\text { cracking/displacement" safety function is maintained for loading conditions associated } \\
\text { with a BDBGM seismic event. (BSC 2004a Table IV-1) }\end{array}$ \\
\hline & & & & $\begin{array}{l}\text { - The structure shall be designed for the loads associated with the maximum observed } \\
\text { hourly precipitation event (with a 100-year return period). (BSC 2004g Section 6.1.1.1.2 } \\
\text { and BSC 2005b Section 4.3.2) }\end{array}$ \\
\hline & $\begin{array}{l}\text { Support } \\
\text { Structures } \\
\text { (including Utility } \\
\text { Buildings and } \\
\text { Personnel } \\
\text { Barriers) }\end{array}$ & N/A & Non-SC & $\begin{array}{l}\text { Not applicable. None of the SSC functions associated with these subsystems are credited } \\
\text { for the prevention or mitigation of an event sequence. }\end{array}$ \\
\hline & $\begin{array}{l}\text { Aircraft Protection } \\
\text { Barrier that } \\
\text { Surrounds the } \\
\text { Aging Pads }\end{array}$ & ITS & SC & $\begin{array}{l}\text { - A barrier, to be at least as tall as the aging casks and to be located in proximity to the } \\
\text { fence line of the aging pads, shall be provided surrounding the aging pads such that the } \\
\text { barrier would not be breached by an F-16 aircraft crashing into the barrier at the speed } \\
\text { corresponding to the 95th percentile from a probability distribution estimated from historical } \\
\text { F-16 crashes. (BSC 2005d Section 5.1.6) }\end{array}$ \\
\hline
\end{tabular}




\begin{tabular}{|c|c|c|c|c|}
\hline $\begin{array}{l}\text { System or } \\
\text { Subsystem }\end{array}$ & $\begin{array}{l}\text { Component } \\
\text { or Function }\end{array}$ & $\begin{array}{l}\text { ITS or } \\
\text { ITWI }\end{array}$ & $\begin{array}{l}\text { Safety } \\
\text { Category }\end{array}$ & Nuclear Safety Design Bases \\
\hline Aging Cask & Site-Specific Cask & ITS & $\mathrm{SC}$ & 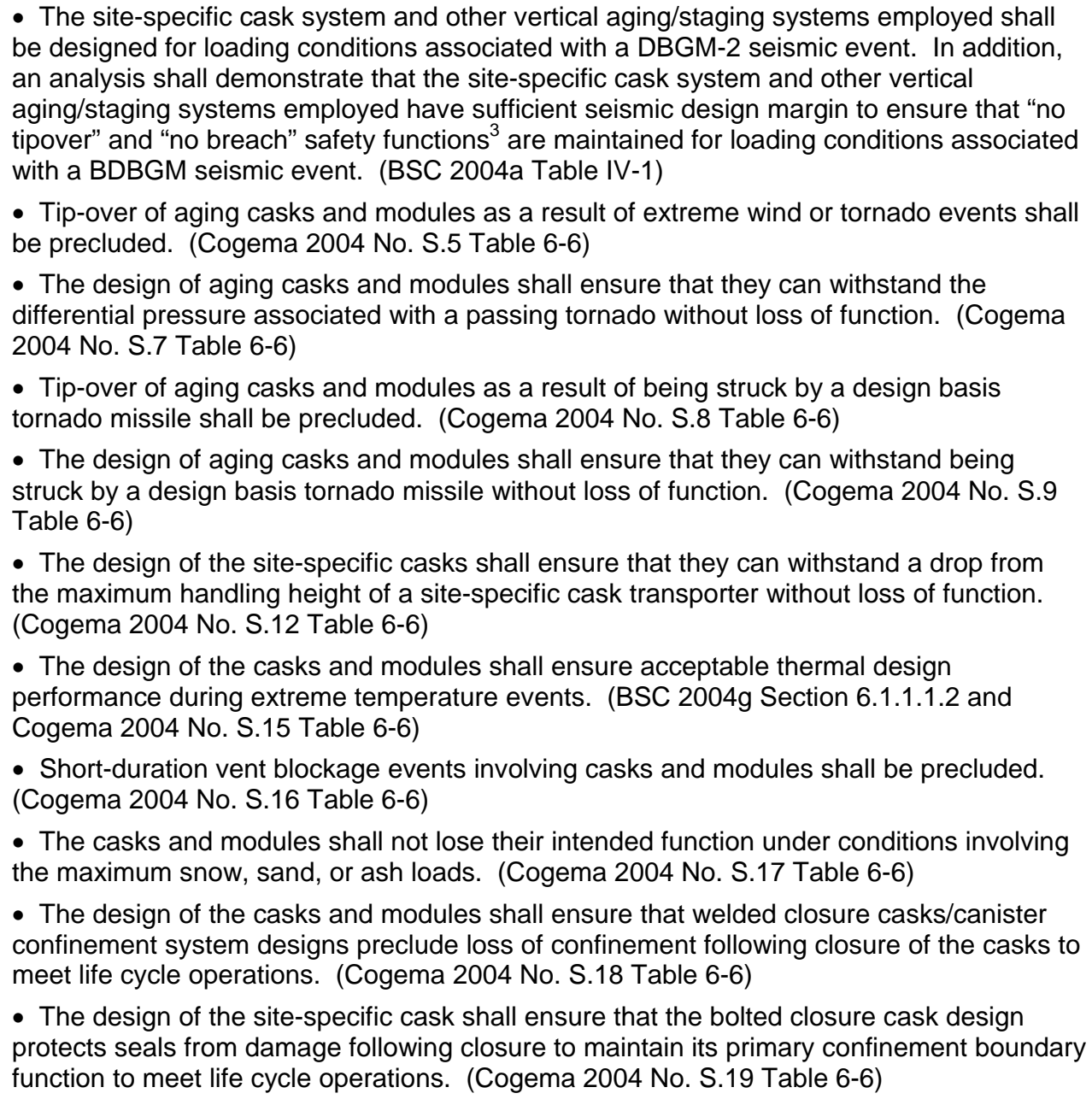 \\
\hline
\end{tabular}




\begin{tabular}{|c|c|c|c|c|}
\hline $\begin{array}{l}\text { System or } \\
\text { Subsystem }\end{array}$ & $\begin{array}{l}\text { Component } \\
\text { or Function }\end{array}$ & $\begin{array}{l}\text { ITS or } \\
\text { ITWI }\end{array}$ & $\begin{array}{l}\text { Safety } \\
\text { Category }\end{array}$ & Nuclear Safety Design Bases \\
\hline $\begin{array}{l}\text { Aging Cask } \\
\text { (continued) }\end{array}$ & $\begin{array}{l}\text { Site-Specific Cask } \\
\text { (continued) }\end{array}$ & ITS & SC & $\begin{array}{l}\text { - Site-specific casks shall be designed to ensure nuclear criticality safety with optimum } \\
\text { moderation and the most reactive waste forms. Criticality safety will be maintained despite } \\
\text { any geometric rearrangements due to a drop or other handling incident. (BSC } 2005 \mathrm{~b} \\
\text { Section 5.1.1.4) } \\
\text { - In the event of a credible fire, the wall temperature of a loaded site-specific cask, being } \\
\text { handled or at rest, shall not exceed its allowable operating range }{ }^{5} \text {. (BSC 2004c Section } \\
5.1 .2 .4 \text { ) } \\
\text { - In the event of a credible fire, the wall temperature of a loaded site-specific cask with } \\
\text { docking ring installed shall not exceed its allowable operating range } e^{2,5} \text {. (BSC 2004c } \\
\text { Section 5.1.2.15) } \\
\text { - A site-specific cask shall not breach as a result of the credible fire }{ }^{5} \text {. } \\
\text { - The design of the horizontal DPC shall ensure that it has sufficient structural design } \\
\text { margin to withstand maximum ram force events. (Cogema } 2004 \text { No. S.27 Table 6-6) }\end{array}$ \\
\hline & $\begin{array}{l}\text { Horizontal Aging } \\
\text { Module }\end{array}$ & ITS & SC & $\begin{array}{l}\text { - HAMs shall be designed for loading conditions associated with a DBGM-2 seismic event. } \\
\text { In addition, an analysis shall demonstrate that the HAMs have sufficient seismic design } \\
\text { margin to ensure that a "no collapse" safety function }{ }^{3} \text { is maintained for loading conditions } \\
\text { associated with a BDBGM seismic event. (BSC } 2004 \text { a Table IV-1) } \\
\text { - Tip-over of aging casks and modules as a result of extreme wind or tornado events shall } \\
\text { be precluded. (Cogema } 2004 \text { No. S.5 Table 6-6) } \\
\text { - The design of aging casks and modules shall ensure that they can withstand the } \\
\text { differential pressure associated with a passing tornado without loss of function. (Cogema } \\
2004 \text { No. S.7 Table 6-6) } \\
\text { - Tip-over of aging casks and modules as a result of being struck by a design basis } \\
\text { tornado missile shall be precluded. (Cogema } 2004 \text { No. S.8 Table 6-6) } \\
\text { - The design of aging casks and modules shall ensure that they can withstand being } \\
\text { struck by a design basis tornado missile without loss of function. (Cogema } 2004 \text { No. S.9 } \\
\text { Table 6-6) } \\
\text { - The design of the casks and modules shall ensure acceptable thermal design } \\
\text { performance during extreme temperature events. (BSC } 20049 \text { Section } 6.1 .1 .1 .2 \text { and } \\
\text { Cogema } 2004 \text { No. S.15 Table 6-6) }\end{array}$ \\
\hline
\end{tabular}




\begin{tabular}{|c|c|c|c|c|}
\hline $\begin{array}{l}\text { System or } \\
\text { Subsystem }\end{array}$ & $\begin{array}{l}\text { Component } \\
\text { or Function }\end{array}$ & $\begin{array}{l}\text { ITS or } \\
\text { ITWI }\end{array}$ & $\begin{array}{l}\text { Safety } \\
\text { Category }\end{array}$ & Nuclear Safety Design Bases \\
\hline $\begin{array}{l}\text { Aging Cask } \\
\text { (continued) }\end{array}$ & $\begin{array}{l}\text { Horizontal Aging } \\
\text { Module } \\
\text { (continued) }\end{array}$ & ITS & SC & $\begin{array}{l}\text { - Short-duration vent blockage events involving casks and modules shall be precluded. } \\
\text { (Cogema } 2004 \text { No. S.16 Table 6-6) } \\
\text { - The casks and modules shall not lose their intended function under conditions involving } \\
\text { the maximum snow, sand, or ash loads. (Cogema } 2004 \text { No. S.17 Table 6-6) } \\
\text { - The design of the casks and modules shall ensure that welded closure casks/canister } \\
\text { confinement system designs preclude loss of confinement following closure of the casks to } \\
\text { meet life cycle operations. (Cogema } 2004 \text { No. S.18 Table 6-6) }\end{array}$ \\
\hline \multicolumn{5}{|c|}{ SNF/HLW Transfer System } \\
\hline WP Loadout & $\begin{array}{l}\text { WP Handling } \\
\text { Crane (DTF, } \\
\text { Room 1044); } 100 \\
\text { ton }\end{array}$ & ITS & SC & $\begin{array}{l}\text { - The drop rate for cranes involved in handling waste forms and their associated } \\
\text { containers shall be less than or equal to } 1 \times 10^{-5} \mathrm{drops} / \text { transfer, regardless of cause, } \\
\text { including human error, failure of equipment such as yokes and grapples, or a combination } \\
\text { of the two. (BSC 2005b Section } 5.1 .1 .10 \text { ) } \\
\text { - Upon a loss of power, this crane shall be designed to stop, retain its load, and enter a } \\
\text { locked mode; upon a restoration of power, this crane shall stay in the locked mode until } \\
\text { operator action is taken. (BSC } 2005 \mathrm{~b} \text { Section } 5.1 .2 .1 \text { ) } \\
\text { - The conditional probability of the crane exceeding a lift-height limit, given that a drop has } \\
\text { occurred, shall be less than or equal to } 1 \times 10^{-4} \text {. (BSC 2005b Section 5.1.1.12) } \\
\text { - The lift height limits for the sealed and unsealed, loaded WPs handled by this crane are } \\
\text { provided in Table C-1 in Appendix C. These WPs include: } \\
\text { 1. Unsealed, loaded WPs containing commercial SNF, standardized DOE SNF } \\
\text { canisters, DOE HLW canisters, naval SNF canisters, or DOE MCOs. } \\
\text { 2. Sealed WPs containing commercial SNF, standardized DOE SNF canisters, DOE } \\
\text { HLW canisters, naval SNF canisters, or DOE MCOs. } \\
\text { - This crane system shall be designed for loading conditions associated with a DBGM-2 } \\
\text { seismic event and maintain its load. In addition, an analysis shall demonstrate that this } \\
\text { crane system has sufficient seismic design margin to ensure that a "no drop" safety } \\
\text { function is maintained for loading conditions associated with a BDBGM seismic event. } \\
\text { (BSC } 2004 \text { Ta Table IV-1) }\end{array}$ \\
\hline
\end{tabular}




\begin{tabular}{|c|c|c|c|c|}
\hline $\begin{array}{l}\text { System or } \\
\text { Subsystem }\end{array}$ & $\begin{array}{l}\text { Component } \\
\text { or Function }\end{array}$ & $\begin{array}{l}\text { ITS or } \\
\text { ITWI }\end{array}$ & $\begin{array}{c}\text { Safety } \\
\text { Category }\end{array}$ & Nuclear Safety Design Bases \\
\hline $\begin{array}{l}\text { WP Loadout } \\
\text { (continued) }\end{array}$ & \begin{tabular}{|l|} 
WP Handling \\
Crane (DTF, \\
Room 1044); 100 \\
ton (continued)
\end{tabular} & ITS & SC & $\begin{array}{l}\text { - This crane shall not be capable of moving above a speed limit for overhead crane } \\
\text { transfers such that a collision at the speed limit would not breach a loaded, sealed WP. } \\
\text { (BSC 2005b Section 5.1.1.19) } \\
\text { - This crane shall not be capable of exerting sufficient force to breach a WP as the result } \\
\text { of attempts to overcome mechanical constraints. (BSC } 2005 \mathrm{~b} \text { Section } 5.1 .1 .20 \text { ) } \\
\text { - In the event of a credible fire in an area where waste forms are present, the temperature } \\
\text { of the crane that handles or transports SNF/HLW shall not reach a level that would make it } \\
\text { drop its load. (BSC 2004c Section 5.1.3.1) } \\
\text { - A drop of a load from a crane that handles SNF/HLW due to a spurious signal caused by } \\
\text { a fire shall have a probability of less than } 1 \times 10^{-4} \text { over the life of the facility. (BSC } 2004 \mathrm{c} \\
\text { Section 5.1.3.4; BSC 2005b Section } 6.1 .1 .1 \text { ) }\end{array}$ \\
\hline & $\begin{array}{l}\text { WP Loadout } \\
\text { Handling Crane } \\
\text { (DTF Room } \\
\text { 1088); } 100 \text { ton }\end{array}$ & ITS & SC & $\begin{array}{l}\text { - The drop rate for cranes involved in handling waste forms and their associated } \\
\text { containers shall be less than or equal to } 1 \times 10^{-5} \text { drops/transfer, regardless of cause, } \\
\text { including human error, failure of equipment such as yokes and grapples, or a combination } \\
\text { of the two. (BSC 2005b Section } 5.1 .1 .10 \text { ) } \\
\text { - Upon a loss of power, this crane shall be designed to stop, retain its load, and enter a } \\
\text { locked mode; upon a restoration of power, this crane shall stay in the locked mode until } \\
\text { operator action is taken. (BSC } 2005 \mathrm{~b} \text { Section } 5.1 .2 .1 \text { ) } \\
\text { - The conditional probability of the crane exceeding a lift-height limit, given that a drop has } \\
\text { occurred, shall be less than or equal to } 1 \times 10^{-4} \text {. (BSC 2005b Section 5.1.1.12) } \\
\text { - This crane system shall be designed for loading conditions associated with a DBGM-2 } \\
\text { seismic event and maintain its load. In addition, an analysis shall demonstrate that the } \\
\text { crane system has sufficient seismic design margin to ensure that a "no drop" safety } \\
\text { function is maintained for loading conditions associated with a BDBGM seismic event. } \\
\text { (BSC } 2004 a \text { Table IV-1) } \\
\text { - The lift height limits for the sealed WPs handled by this crane are provided in Table C-1 } \\
\text { in Appendix C. These WPs include sealed WPs containing commercial SNF, standardized } \\
\text { DOE SNF canisters, DOE HLW canisters, naval SNF canisters, or DOE MCOs. } \\
\text { - This crane shall not be capable of moving above a speed limit for overhead crane } \\
\text { transfers such that a collision at the speed limit would not breach a loaded, sealed WP. } \\
\text { (BSC } 2005 \mathrm{~b} \text { Section 5.1.1.19) }\end{array}$ \\
\hline
\end{tabular}




\begin{tabular}{|c|c|c|c|c|}
\hline $\begin{array}{l}\text { System or } \\
\text { Subsystem }\end{array}$ & $\begin{array}{l}\text { Component } \\
\text { or Function }\end{array}$ & $\begin{array}{l}\text { ITS or } \\
\text { ITWI }\end{array}$ & $\begin{array}{c}\text { Safety } \\
\text { Category }\end{array}$ & Nuclear Safety Design Bases \\
\hline \multirow[t]{3}{*}{$\begin{array}{l}\text { WP Loadout } \\
\text { (continued) }\end{array}$} & $\begin{array}{l}\text { WP Loadout } \\
\text { Handling Crane } \\
\text { (DTF Room } \\
\text { 1088); } 100 \text { ton } \\
\text { (continued) }\end{array}$ & ITS & SC & $\begin{array}{l}\text { - This crane shall not be capable of exerting sufficient force to breach a WP as the result } \\
\text { of attempts to overcome mechanical constraints. (BSC } 2005 \text { b Section } 5.1 .1 .20 \text { ) } \\
\text { - In the event of a credible fire in an area where waste forms are present, the temperature } \\
\text { of the crane that handles or transports SNF/HLW shall not reach a level that would make it } \\
\text { drop its load. (BSC } 2004 \mathrm{c} \text { Section 5.1.3.1) } \\
\text { - A drop of a load from a crane that handles SNF/HLW due to a spurious signal caused by } \\
\text { a fire shall have a probability of less than } 1 \times 10^{-4} \text { over the life of the facility. (BSC 2004c } \\
\text { Section 5.1.3.4; BSC 2005b Section } 6.1 .1 .1 \text { ) }\end{array}$ \\
\hline & $\begin{array}{l}\text { Crane Lifting } \\
\text { Yokes }\end{array}$ & ITS & SC & $\begin{array}{l}\text { - Crane lifting yokes shall be designed for loading conditions associated with a DBGM-2 } \\
\text { seismic event. In addition, an analysis shall demonstrate that the crane lifting yokes have } \\
\text { sufficient seismic design margin to ensure that a "no drop" safety function }{ }^{3} \text { is maintained } \\
\text { for loading conditions associated with a BDBGM seismic event. (BSC 2004a Table IV-1) }\end{array}$ \\
\hline & \begin{tabular}{|l} 
Trolley, Pedestal, \\
and Hold-Down \\
Devices (DTF)
\end{tabular} & ITS & SC & $\begin{array}{l}\text { - Upon a loss of power, this trolley shall be designed to stop, retain its load, and enter a } \\
\text { locked mode; upon a restoration of power, this trolley shall stay in the locked mode until } \\
\text { operator action is taken. (BSC 2005b Section 5.1.2.2) } \\
\text { - The trolley system shall be designed for loading conditions associated with a DBGM-2 } \\
\text { seismic event to maintain trolley stability and prevent waste container slapdown. In } \\
\text { addition, an analysis shall demonstrate that the trolley system has sufficient seismic design } \\
\text { margin to ensure that a "no slapdown" safety function is maintained for loading conditions } \\
\text { associated with a BDBGM seismic event. (BSC } 2004 \text { a Table IV-1) } \\
\text { - The trolley shall be designed with an inherent speed limit such that a collision at the } \\
\text { trolley speed limit would not cause the trolley to drop its load. (BSC 2005b Section } \\
\text { 5.1.1.61) }\end{array}$ \\
\hline
\end{tabular}


Table A-II. Nuclear Safety Design Bases of Systems and Subsystems

\begin{tabular}{|c|c|c|c|c|}
\hline $\begin{array}{l}\text { System or } \\
\text { Subsystem }\end{array}$ & $\begin{array}{l}\text { Component } \\
\text { or Function }\end{array}$ & $\begin{array}{l}\text { ITS or } \\
\text { ITWI }\end{array}$ & $\begin{array}{l}\text { Safety } \\
\text { Category }\end{array}$ & Nuclear Safety Design Bases \\
\hline \multirow[t]{2}{*}{$\begin{array}{l}\text { WP Loadout } \\
\text { (continued) }\end{array}$} & $\begin{array}{l}\text { Trolley, Pedestal, } \\
\text { and Hold-Down } \\
\text { Devices (DTF) } \\
\text { (continued) }\end{array}$ & ITS & SC & $\begin{array}{l}\text { - Pedestals and hold-down devices shall be designed for loading conditions associated } \\
\text { with a DBGM-2 seismic event. In addition, an analysis shall demonstrate that the } \\
\text { pedestals and hold-down devices have sufficient seismic design margin to ensure that a } \\
\text { "no tipover" safety function }{ }^{3} \text { is maintained for loading conditions associated with a BDBGM } \\
\text { seismic event. (BSC } 2004 a \text { Table IV-1) } \\
\text { - Loaded transfer trolleys shall not derail or drop their loads. (BSC 2005b Section } \\
5.1 .1 .36 \text { ) } \\
\text { - In the event of a credible fire in an area where waste forms are present, the temperature } \\
\text { of the machinery that handles or transports SNF/HLW shall not reach a level that would } \\
\text { make it drop its load. (BSC } 2004 \mathrm{c} \text { Section } 5.1 .3 .1 \text { ) } \\
\text { - A tipover and breach of a cask while on machinery that transports SNF/HLW due to } \\
\text { uncontrolled movements produced by a loss of power or a spurious signal caused by a fire } \\
\text { shall have a probability of less than } 1 \times 10^{-4} \text { over the life of the facility. (BSC } 2004 \mathrm{c} \\
\text { Section 5.1.3.4; BSC } 2005 \mathrm{~b} \text { Section } 6.1 .1 .1 \text { ) }\end{array}$ \\
\hline & $\begin{array}{l}\text { WP Tilting } \\
\text { Machine (DTF, } \\
\text { CHF, FHF) }\end{array}$ & ITS & SC & $\begin{array}{l}\text { - The WP tilting machine system shall be designed for loading conditions associated with } \\
\text { a DBGM-2 seismic event to maintain stability and prevent a WP drop or slapdown. In } \\
\text { addition, an analysis shall demonstrate that the WP tilting machine system has sufficient } \\
\text { seismic design margin to ensure that "no drop" and "no slapdown" safety functions }{ }^{3} \text { are } \\
\text { maintained for loading conditions associated with a BDBGM seismic event. (BSC } 2004 a \\
\text { Table IV-1) } \\
\text { - The WP tilting machine shall be designed to prevent backward slapdowns. (BSC } 2005 \mathrm{~b} \\
\text { Section 5.1.1.53) } \\
\text { - The WP tilting machine shall include measures to prevent movement or release of the } \\
\text { lock on WP trunnions while the WP is being lowered onto the emplacement pallet. (BSC } \\
\text { 2005b Section 5.1.1.53) } \\
\text { - An impact or collision between the WP tilting machine and a WP shall not breach the } \\
\text { WP or cause it to fall off the emplacement pallet. (BSC 2005b Section 5.1.3.10) }\end{array}$ \\
\hline
\end{tabular}




\begin{tabular}{|c|c|c|c|c|}
\hline $\begin{array}{l}\text { System or } \\
\text { Subsystem }\end{array}$ & $\begin{array}{l}\text { Component } \\
\text { or Function }\end{array}$ & $\begin{array}{l}\text { ITS or } \\
\text { ITWI }\end{array}$ & $\begin{array}{l}\text { Safety } \\
\text { Category }\end{array}$ & Nuclear Safety Design Bases \\
\hline $\begin{array}{l}\text { WP Loadout } \\
\text { (continued) }\end{array}$ & $\begin{array}{l}\text { WP Turntable } \\
\text { (DTF, CHF, FHF) }\end{array}$ & ITS & SC & $\begin{array}{l}\text { - The WP turntable system shall be designed for loading conditions associated with a } \\
\text { DBGM-2 seismic event to maintain turntable stability and prevent WP tipover. In addition, } \\
\text { an analysis shall demonstrate that the WP turntable system has sufficient seismic design } \\
\text { margin to ensure that a "no tipover" safety function }{ }^{3} \text { is maintained for loading conditions } \\
\text { associated with a BDBGM seismic event. (BSC } 2004 \text { a Table IV-1) } \\
\text { - The premature actuation of the WP turntable (while holding the WP on an emplacement } \\
\text { pallet) before the disengagement of the trunnion collar removal machine shall be } \\
\text { precluded. (BSC 2005b Section 5.1.1.16) } \\
\text { - An impact or collision between the WP turntable and a WP shall not breach the WP or } \\
\text { cause it to fall off the emplacement pallet. (BSC 2005b Section } 5.1 .3 .10 \text { ) }\end{array}$ \\
\hline & \begin{tabular}{|l} 
Trunnion Collar \\
Removal Machine \\
(DTF, CHF, FHF)
\end{tabular} & ITS & SC & $\begin{array}{l}\text { - The trunnion collar removal machine system shall be designed for loading conditions } \\
\text { associated with a DBGM-2 seismic event to prevent slapdown of the WP. In addition, an } \\
\text { analysis shall demonstrate that the trunnion collar removal machine system has sufficient } \\
\text { seismic design margin to ensure that "no slapdown" and "no breach" safety functions }{ }^{3} \text { are } \\
\text { maintained for loading conditions associated with a BDBGM seismic event. (BSC 2004a } \\
\text { Table IV-1) } \\
\text { - The premature actuation of the WP turntable (while holding the WP on an emplacement } \\
\text { pallet) before the disengagement of the trunnion collar removal machine shall be } \\
\text { precluded. (BSC } 2005 \mathrm{~b} \text { Section 5.1.1.16) } \\
\text { - An impact or collision between the trunnion collar removal machine and a WP shall not } \\
\text { breach the WP or cause it to fall off the emplacement pallet. (BSC 2005b Section 5.1.3.10) }\end{array}$ \\
\hline DPC Cutting & $\begin{array}{l}\text { DPC Cutting } \\
\text { Machine (DTF) }\end{array}$ & ITS & SC & $\begin{array}{l}\text { - The design of the DPC cutting machine shall ensure that the DPC lid will prevent } \\
\text { damage to the SNF assembly resulting in radiological release should the cutting machine } \\
\text { fall into or make contact with the DPC. (BSC 2005b Section 5.1.5.3) } \\
\text { - The DPC cutting machine shall preclude a radiological release due to damage inflicted } \\
\text { upon the DPC contents during the cutting process. (BSC 2005b Section 5.1.5.4) } \\
\text { - The DPC cutting machine shall be designed for loading conditions associated with a } \\
\text { DBGM-2 seismic event and to demonstrate sufficient seismic design margin to ensure that } \\
\text { "no failure" and "no fall down" safety functions }{ }^{3} \text { are maintained for loading conditions } \\
\text { associated with a BDBGM seismic event. (BSC 2004a Table IV-1) }\end{array}$ \\
\hline
\end{tabular}




\begin{tabular}{|c|c|c|c|c|}
\hline $\begin{array}{l}\text { System or } \\
\text { Subsystem }\end{array}$ & $\begin{array}{l}\text { Component } \\
\text { or Function }\end{array}$ & $\begin{array}{l}\text { ITS or } \\
\text { ITWI }\end{array}$ & $\begin{array}{c}\text { Safety } \\
\text { Category }\end{array}$ & Nuclear Safety Design Bases \\
\hline $\begin{array}{l}\text { DPC Cutting } \\
\text { (continued) }\end{array}$ & $\begin{array}{l}\text { DPC Docking } \\
\text { Station }\end{array}$ & ITS & $\mathrm{SC}$ & $\begin{array}{l}\text { - A drop or collision involving components associated with a docking port shall not breach } \\
\text { the lid of a transportation cask or site-specific cask situated at the docking port. (BSC } \\
2005 \text { b Section 5.1.1.17) }\end{array}$ \\
\hline Dry Transfer & $\begin{array}{l}\text { Spent Fuel } \\
\text { Transfer Machine } \\
\text { and Grapples } \\
\text { (DTF, FHF) }\end{array}$ & ITS & SC & 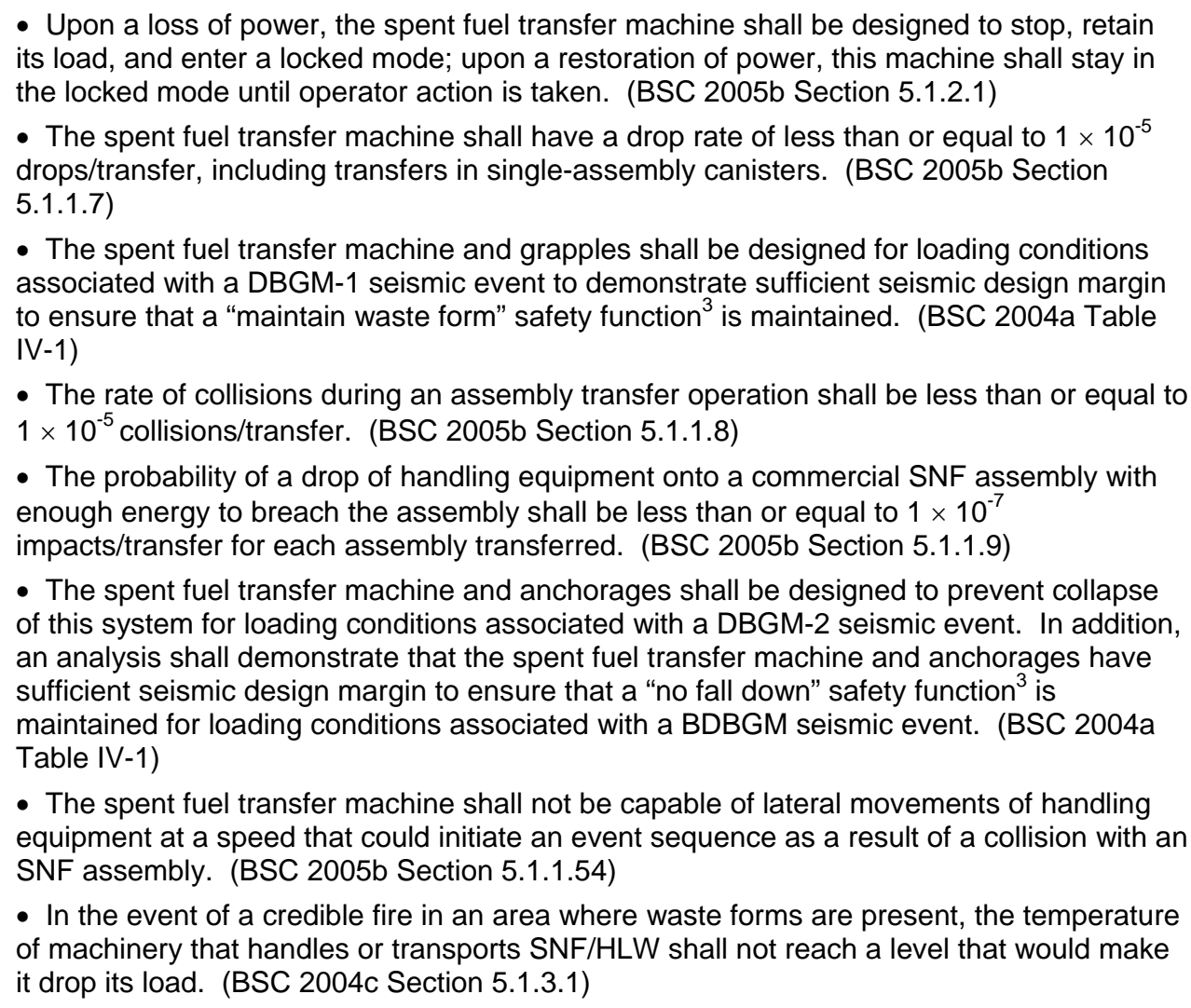 \\
\hline
\end{tabular}




\begin{tabular}{|c|c|c|c|c|}
\hline $\begin{array}{l}\text { System or } \\
\text { Subsystem }\end{array}$ & $\begin{array}{l}\text { Component } \\
\text { or Function }\end{array}$ & $\begin{array}{l}\text { ITS or } \\
\text { ITWI }\end{array}$ & $\begin{array}{c}\text { Safety } \\
\text { Category }\end{array}$ & Nuclear Safety Design Bases \\
\hline $\begin{array}{l}\text { Dry Transfer } \\
\text { (continued) }\end{array}$ & $\begin{array}{l}\text { Spent Fuel } \\
\text { Transfer Machine } \\
\text { and Grapples } \\
\text { (DTF, FHF) } \\
\text { (continued) }\end{array}$ & ITS & SC & $\begin{array}{l}\text { - A drop of a load from machinery that handles SNF due to a spurious signal caused by a } \\
\text { fire shall have a probability of less than } 1 \times 10^{-4} \text { over the life of the facility. (BSC 2004c } \\
\text { Section 5.1.3.4; BSC 2005b Section 6.1.1.1) }\end{array}$ \\
\hline & $\begin{array}{l}\text { Canister/HLW } \\
\text { Handling Crane } \\
\text { (DTF); } 70 \text { ton }\end{array}$ & ITS & SC & 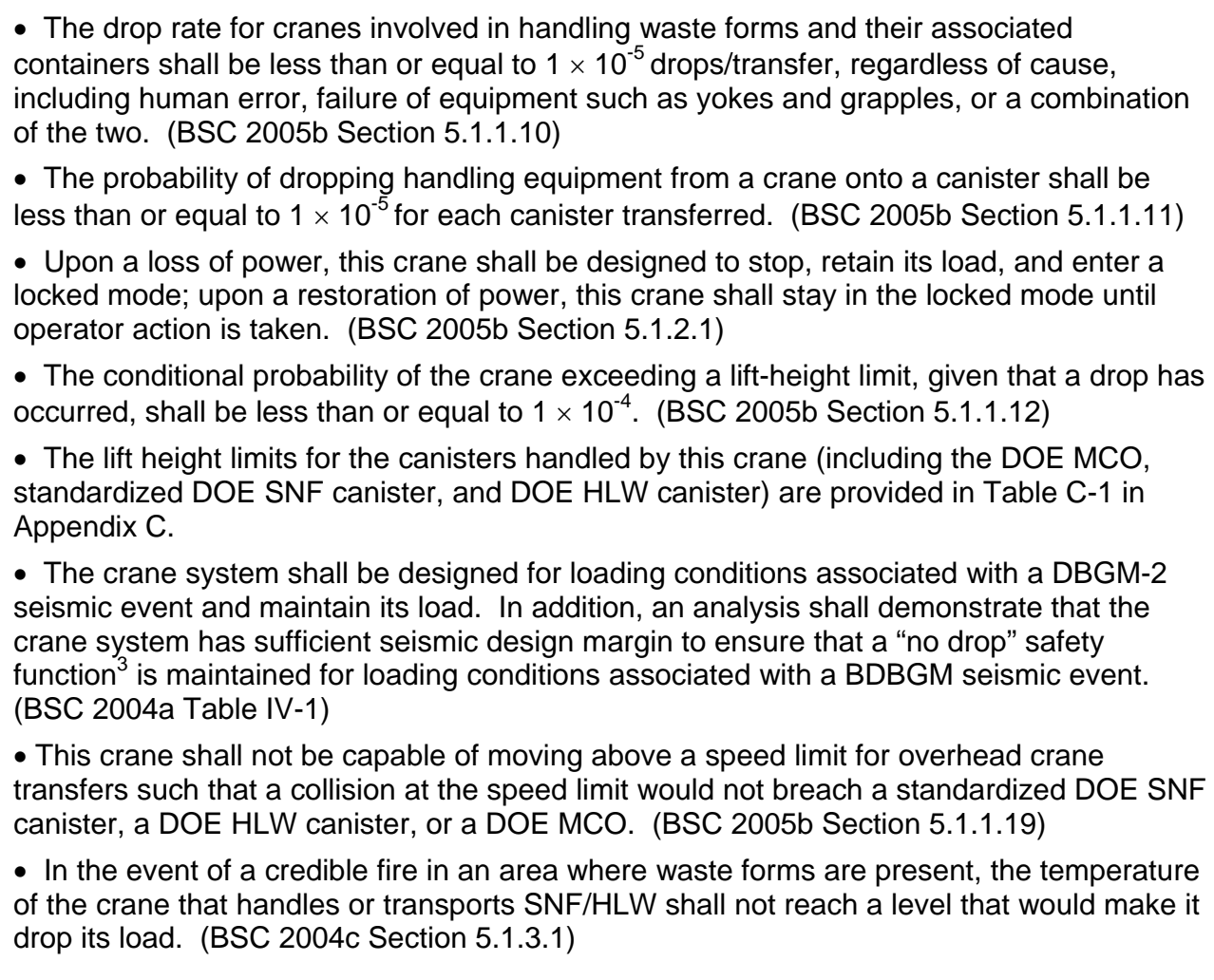 \\
\hline
\end{tabular}


Table A-II. Nuclear Safety Design Bases of Systems and Subsystems

\begin{tabular}{|c|c|c|c|c|}
\hline $\begin{array}{l}\text { System or } \\
\text { Subsystem }\end{array}$ & $\begin{array}{l}\text { Component } \\
\text { or Function }\end{array}$ & $\begin{array}{l}\text { ITS or } \\
\text { ITWI }\end{array}$ & $\begin{array}{l}\text { Safety } \\
\text { Category }\end{array}$ & Nuclear Safety Design Bases \\
\hline \multirow[t]{2}{*}{$\begin{array}{l}\text { Dry Transfer } \\
\text { (continued) }\end{array}$} & $\begin{array}{l}\text { Canister/HLW } \\
\text { Handling Crane } \\
\text { (DTF); } 70 \text { ton } \\
\text { (continued) }\end{array}$ & ITS & SC & $\begin{array}{l}\text { - A drop of a load from a crane that handles SNF/HLW due to a spurious signal caused by } \\
\text { a fire shall have a probability of less than } 1 \times 10^{-4} \text { over the life of the facility. (BSC 2004c } \\
\text { Section 5.1.3.4; BSC } 2005 \text { b Section } 6.1 .1 .1 \text { ) } \\
\text { - This crane shall not be capable of exerting sufficient force to breach a canister as the } \\
\text { result of attempts to overcome mechanical constraints. (BSC 2005b Section 5.1.1.20) }\end{array}$ \\
\hline & $\begin{array}{l}\text { Navy Canister } \\
\text { Handling Crane } \\
\text { (DTF); } 70 \text { ton }\end{array}$ & ITS & SC & $\begin{array}{l}\text { - The drop rate for cranes involved in handling waste forms and their associated } \\
\text { containers shall be less than or equal to } 1 \times 10^{-5} \text { drops/transfer, regardless of cause, } \\
\text { including human error, failure of equipment such as yokes and grapples, or a combination } \\
\text { of the two. (BSC 2005b Section } 5.1 .1 .10 \text { ) } \\
\text { - Upon a loss of power, this crane shall be designed to stop, retain its load, and enter a } \\
\text { locked mode; upon a restoration of power, this crane shall stay in the locked mode until } \\
\text { operator action is taken. (BSC } 2005 b \text { Section } 5.1 .2 .1 \text { ) } \\
\text { - The conditional probability of the crane exceeding a lift-height limit, given that a drop has } \\
\text { occurred, shall be less than or equal to } 1 \times 10^{-4} \text {. (BSC } 2005 b \text { Section 5.1.1.12) } \\
\text { - The lift height limits for the naval SNF canisters handled by this crane are provided in } \\
\text { Table C-1 in Appendix C. } \\
\text { - This crane system shall be designed for loading conditions associated with a DBGM-2 } \\
\text { seismic event and maintain its load. In addition, an analysis shall demonstrate that this } \\
\text { crane system has sufficient seismic design margin to ensure that a "no drop" safety } \\
\text { function is maintained for loading conditions associated with a BDBGM seismic event. } \\
\text { (BSC } 2004 a \text { Table IV-1) } \\
\text { - This crane shall not be capable of moving above a speed limit for overhead crane } \\
\text { transfers such that a collision at the speed limit would not breach a naval SNF canister. } \\
\text { (BSC } 2005 \mathrm{~b} \text { Section } 5.1 .1 .19 \text { ) } \\
\text { - In the event of a credible fire in an area where waste forms are present, the temperature } \\
\text { of the crane that handles or transports SNF/HLW shall not reach a level that would make it } \\
\text { drop its load. (BSC 2004c Section 5.1.3.1) }\end{array}$ \\
\hline
\end{tabular}




\begin{tabular}{|c|c|c|c|c|}
\hline $\begin{array}{l}\text { System or } \\
\text { Subsystem }\end{array}$ & $\begin{array}{l}\text { Component } \\
\text { or Function }\end{array}$ & $\begin{array}{l}\text { ITS or } \\
\text { ITWI }\end{array}$ & $\begin{array}{l}\text { Safety } \\
\text { Category }\end{array}$ & Nuclear Safety Design Bases \\
\hline \multirow[t]{4}{*}{$\begin{array}{l}\text { Dry Transfer } \\
\text { (continued) }\end{array}$} & $\begin{array}{l}\text { Navy Canister } \\
\text { Handling Crane } \\
\text { (DTF); } 70 \text { ton } \\
\text { (continued) }\end{array}$ & ITS & SC & $\begin{array}{l}\text { - A drop of a load from a crane that handles SNF/HLW due to a spurious signal caused by } \\
\text { a fire shall have a probability of less than } 1 \times 10^{-4} \text { over the life of the facility. (BSC } 2004 \mathrm{c} \\
\text { Section 5.1.3.4; BSC } 2005 \text { b Section } 6.1 .1 .1 \text { ) } \\
\text { - This crane shall not be capable of exerting sufficient force to breach a canister as the } \\
\text { result of attempts to overcome mechanical constraints. (BSC 2005b Section 5.1.1.20) }\end{array}$ \\
\hline & $\begin{array}{l}\text { Crane Lifting } \\
\text { Yokes }\end{array}$ & ITS & SC & $\begin{array}{l}\text { - The crane lifting yokes shall be designed for loading conditions associated with a } \\
\text { DBGM-2 seismic event. In addition, an analysis shall demonstrate that the crane lifting } \\
\text { yokes have sufficient seismic design margin to ensure that a "no drop" safety function }{ }^{3} \text { is } \\
\text { maintained for loading conditions associated with a BDBGM seismic event. (BSC 2004a } \\
\text { Table IV-1) }\end{array}$ \\
\hline & $\begin{array}{l}\text { Cask/WP Docking } \\
\text { Stations (DTF, } \\
\text { FHF) }\end{array}$ & ITS & SC & $\begin{array}{l}\text { - A drop or collision involving components associated with a docking port shall not breach } \\
\text { the lid of a transportation cask or site-specific cask situated at the docking port. (BSC } \\
\text { 2005b Section 5.1.1.17) }\end{array}$ \\
\hline & $\begin{array}{l}\text { Canister and SNF } \\
\text { Staging Racks } \\
\text { (DTF) }\end{array}$ & ITS & SC & $\begin{array}{l}\text { - Criticality safety shall be ensured for the commercial SNF assembly staging racks } \\
\text { loaded to capacity with the most reactive commercial SNF assembly accepted at the } \\
\text { repository with moderator control in effect. (BSC } 2005 \mathrm{~b} \text { Section } 5.1 .4 .2 \text { ) } \\
\text { - Criticality safety shall be ensured for commercial SNF assemblies dropped into or onto a } \\
\text { commercial SNF assembly staging rack with moderator control in effect. (BSC } 2005 \mathrm{~b} \\
\text { Section } 5.1 .4 .3 \text { ) } \\
\text { - The most reactive configuration of standardized DOE SNF canisters shall be capable of } \\
\text { being loaded into the canister staging racks (with credit for moderator control) without } \\
\text { leading to a nuclear criticality. (BSC 2005b Section 5.1.1.2) } \\
\text { - The canister and SNF staging racks shall be designed for loading conditions associated } \\
\text { with a DBGM-2 seismic event for stability and distortion such as to maintain } \\
\text { assembly/canister geometry in the rack. In addition, analyses shall demonstrate that the } \\
\text { staging racks have sufficient seismic design margin to ensure that distortion of the racks is } \\
\text { limited and stability is maintained for loading conditions associated with a BDBGM seismic } \\
\text { event. (BSC 2004a Table IV-1) }\end{array}$ \\
\hline
\end{tabular}




\begin{tabular}{|c|c|c|c|c|}
\hline $\begin{array}{l}\text { System or } \\
\text { Subsystem }\end{array}$ & $\begin{array}{l}\text { Component } \\
\text { or Function }\end{array}$ & $\begin{array}{l}\text { ITS or } \\
\text { ITWI }\end{array}$ & $\begin{array}{l}\text { Safety } \\
\text { Category }\end{array}$ & Nuclear Safety Design Bases \\
\hline $\begin{array}{l}\text { Dry Transfer } \\
\text { (continued) }\end{array}$ & $\begin{array}{l}\text { Canister Staging } \\
\text { Racks (CHF) }\end{array}$ & ITS & SC & $\begin{array}{l}\text { - The most reactive configuration of standardized DOE SNF canisters shall be capable of } \\
\text { being loaded into canister staging racks (with credit for moderator control) without causing } \\
\text { a nuclear criticality. (BSC 2005b Section 5.1.1.2) } \\
\text { - The staging racks shall be designed for loading conditions associated with a DBGM-2 } \\
\text { seismic event for stability and distortion such as to maintain canister geometry in the rack. } \\
\text { In addition, analyses shall demonstrate that the staging racks have sufficient seismic } \\
\text { design margin to ensure that distortion of the racks is limited and stability is maintained for } \\
\text { loading conditions associated with a BDBGM seismic event. (BSC 2004a Table IV-1) }\end{array}$ \\
\hline \multicolumn{5}{|c|}{ Subsurface Ventilation System } \\
\hline $\begin{array}{l}\text { Subsurface } \\
\text { Ventilation }\end{array}$ & Entire & $\mathrm{N} / \mathrm{A}$ & Non-SC & $\begin{array}{l}\text { Not applicable. None of the SSC functions associated with these subsystems are credited } \\
\text { for the prevention or mitigation of an event sequence. }\end{array}$ \\
\hline \multicolumn{5}{|r|}{ Surface Industrial HVAC } \\
\hline $\begin{array}{l}\text { Surface Industrial } \\
\text { HVAC }\end{array}$ & $\begin{array}{l}\text { Inlet and Outlet } \\
\text { Dampers and } \\
\text { Ventilation } \\
\text { Ducting (including } \\
\text { stack) for Fuel } \\
\text { Element Staging } \\
\text { Areas (DTF Only) }\end{array}$ & ITS & SC & $\begin{array}{l}\text { - The inlet and outlet dampers and ventilation ducting for the fuel element staging areas } \\
\text { shall be designed for loading conditions associated with a DBGM-1 seismic event and } \\
\text { demonstrate sufficient seismic design margin to a "no failure" safety function }{ }^{3} \text {. (BSC } \\
\text { 2004a Table IV-1) } \\
\text { - The ventilation stack for the fuel element staging areas (DTF only) shall be designed for } \\
\text { loading conditions associated with a DBGM-1 seismic event and demonstrate sufficient } \\
\text { seismic design margin to a "controlled failure" safety function }{ }^{3} \text {. (BSC 2004a Table IV-1) } \\
\text { - A loss of HVAC for up to } 30 \text { days in areas where SNF or HLW is handled or staged shall } \\
\text { not cause waste form temperatures to exceed allowable limits. } \\
\text { 5.1.2.4) }\end{array}$ \\
\hline
\end{tabular}




\begin{tabular}{|c|c|c|c|c|}
\hline $\begin{array}{l}\text { System or } \\
\text { Subsystem }\end{array}$ & $\begin{array}{l}\text { Component } \\
\text { or Function }\end{array}$ & $\begin{array}{l}\text { ITS or } \\
\text { ITWI }\end{array}$ & $\begin{array}{l}\text { Safety } \\
\text { Category }\end{array}$ & Nuclear Safety Design Bases \\
\hline $\begin{array}{l}\text { Surface Industrial } \\
\text { HVAC (continued) }\end{array}$ & $\begin{array}{l}\text { SSCs Other Than } \\
\text { the Inlet and } \\
\text { Outlet Dampers } \\
\text { and Ventilation } \\
\text { Ducting (including } \\
\text { stack) for Fuel } \\
\text { Element Staging } \\
\text { Areas (DTF Only) }\end{array}$ & N/A & Non-SC & $\begin{array}{l}\text { Not applicable. None of the SSC functions associated with these subsystems are credited } \\
\text { for the prevention or mitigation of an event sequence. }\end{array}$ \\
\hline \multicolumn{5}{|r|}{ Surface Nuclear HVAC } \\
\hline $\begin{array}{l}\text { Primary } \\
\text { Confinement }\end{array}$ & Entire (DTF, FHF) & ITS & SC & $\begin{array}{l}\text { - To mitigate the worker and public doses following a Category } 1 \text { event sequence, the } \\
\text { Surface Nuclear HVAC system shall be equipped with HEPA filters. A two-stage HEPA } \\
\text { filtration system with a particulate removal efficiency of at least } 99 \% \text { per stage is required. } \\
\text { This requirement applies to the DTF and the FHF. (BSC 2005c Section 4.8) } \\
\text { - The HEPA filters and vent ducts (exhaust ducting and dampers) shall be designed for } \\
\text { loading conditions associated with a DBGM-1 seismic event and demonstrate sufficient } \\
\text { seismic design margin to a "no discharge" safety function'. (BSC 2004a Table IV-1) } \\
\text { - The probability that the HVAC system, including HEPA filtration in the primary } \\
\text { confinement areas of the DTF and FHF, becomes unavailable during a 4-hour mission time } \\
\text { shall be } 0.01 \text { or less, without credit for backup electrical power. (BSC 2005b Section } \\
\text { 5.1.1.48) } \\
\text { - The primary nuclear HEPA filtered ventilation system shall provide a decontamination } \\
\text { factor of } 10^{4} \text { for particulate. (BSC } 2005 c \text { Section 4.8) } \\
\text { - A loss of HVAC for up to } 30 \text { days in areas where SNF or HLW is handled or staged shall } \\
\text { not cause waste form temperatures to exceed allowable limits. (BSC } 2005 \mathrm{~b} \text { Section } \\
\text { 5.1.2.4) }\end{array}$ \\
\hline $\begin{array}{l}\text { Secondary } \\
\text { Confinement }\end{array}$ & Entire & N/A & Non-SC & $\begin{array}{l}\text { Not applicable. None of the SSC functions associated with these subsystems are credited } \\
\text { for the prevention or mitigation of an event sequence. }\end{array}$ \\
\hline
\end{tabular}


Table A-II. Nuclear Safety Design Bases of Systems and Subsystems

\begin{tabular}{|c|c|c|c|c|}
\hline $\begin{array}{l}\text { System or } \\
\text { Subsystem }\end{array}$ & $\begin{array}{l}\text { Component } \\
\text { or Function }\end{array}$ & $\begin{array}{l}\text { ITS or } \\
\text { ITWI }\end{array}$ & $\begin{array}{l}\text { Safety } \\
\text { Category }\end{array}$ & Nuclear Safety Design Bases \\
\hline $\begin{array}{l}\text { Tertiary } \\
\text { Confinement }\end{array}$ & Entire & $\mathrm{N} / \mathrm{A}$ & Non-SC & $\begin{array}{l}\text { Not applicable. None of the SSC functions associated with these subsystems are credited } \\
\text { for the prevention or mitigation of an event sequence. }\end{array}$ \\
\hline \multicolumn{5}{|r|}{ Transportation Cask } \\
\hline $\begin{array}{l}\text { Transportation } \\
\text { Cask }\end{array}$ & Entire & ITS & $\mathrm{SC}$ & $\begin{array}{l}\text { Transportation casks provide adequate protection against external hazards on the } \\
\text { repository site. See footnotes } 1,4 \text {, and } 5 \text {. }\end{array}$ \\
\hline \multicolumn{5}{|r|}{ WP Closure System } \\
\hline $\begin{array}{l}\text { Welding } \\
\text { (Equipment) }\end{array}$ & Entire & N/A & Non-SC & $\begin{array}{l}\text { Not applicable. None of the SSC functions associated with these subsystems are credited } \\
\text { for the prevention or mitigation of an event sequence. }\end{array}$ \\
\hline $\begin{array}{l}\text { Inerting } \\
\text { (Equipment) }\end{array}$ & Entire & N/A & Non-SC & $\begin{array}{l}\text { Not applicable. None of the SSC functions associated with these subsystems are credited } \\
\text { for the prevention or mitigation of an event sequence. }\end{array}$ \\
\hline $\begin{array}{l}\text { Non-Destructive } \\
\text { Testing } \\
\text { (Equipment) }\end{array}$ & Entire & N/A & Non-SC & $\begin{array}{l}\text { Not applicable. None of the SSC functions associated with these subsystems are credited } \\
\text { for the prevention or mitigation of an event sequence. }\end{array}$ \\
\hline $\begin{array}{l}\text { Stress Mitigation } \\
\text { (Equipment) }\end{array}$ & Entire & $\mathrm{N} / \mathrm{A}$ & Non-SC & $\begin{array}{l}\text { Not applicable. None of the SSC functions associated with these subsystems are credited } \\
\text { for the prevention or mitigation of an event sequence. }\end{array}$ \\
\hline WP Identification & Entire & N/A & Non-SC & $\begin{array}{l}\text { Not applicable. None of the SSC functions associated with these subsystems are credited } \\
\text { for the prevention or mitigation of an event sequence. }\end{array}$ \\
\hline $\begin{array}{l}\text { Spread Ring } \\
\text { Installation }\end{array}$ & Entire & $\mathrm{N} / \mathrm{A}$ & Non-SC & $\begin{array}{l}\text { Not applicable. None of the SSC functions associated with these subsystems are credited } \\
\text { for the prevention or mitigation of an event sequence. }\end{array}$ \\
\hline Material Handling & Entire & N/A & Non-SC & $\begin{array}{l}\text { Not applicable. None of the SSC functions associated with these subsystems are credited } \\
\text { for the prevention or mitigation of an event sequence. }\end{array}$ \\
\hline
\end{tabular}


Table A-II. Nuclear Safety Design Bases of Systems and Subsystems

\begin{tabular}{|l|l|l|l|l|}
\hline \multicolumn{1}{|c|}{$\begin{array}{c}\text { System or } \\
\text { Subsystem }\end{array}$} & \multicolumn{1}{|c|}{$\begin{array}{c}\text { Component } \\
\text { or Function }\end{array}$} & $\begin{array}{c}\text { ITS or } \\
\text { ITWI }\end{array}$ & $\begin{array}{c}\text { Safety } \\
\text { Category }\end{array}$ & \multicolumn{1}{|c|}{ Nuclear Safety Design Bases } \\
\hline $\begin{array}{l}\text { Remote } \\
\text { Equipment } \\
\text { Maintenance }\end{array}$ & Entire & N/A & Non-SC & $\begin{array}{l}\text { Not applicable. None of the SSC functions associated with these subsystems are credited } \\
\text { for the prevention or mitigation of an event sequence. }\end{array}$ \\
\hline $\begin{array}{l}\text { Operations } \\
\text { Control }\end{array}$ & Entire & N/A & Non-SC & $\begin{array}{l}\text { Not applicable. None of the SSC functions associated with these subsystems are credited } \\
\text { for the prevention or mitigation of an event sequence. }\end{array}$ \\
\hline
\end{tabular}

FOOTNOTES:

1. Functions of the transportation casks are credited to prevent or mitigate event sequences. The certification process for transportation casks under $10 \mathrm{CFR}$ Part 71 [DIRS 104091] considers severe transportation accident conditions and conditions of normal transport. The precedent that licensed casks provide adequate protection against all hazards that apply during the transportation phase establishes the basis that the casks will continue to provide adequate protection on site at the repository.

g 2. This requirement may be equivalently replaced by a set of two sub-requirements. The first sub-requirement is the fire requirement applicable to the waste form being sheltered by the waste form container. The second sub-requirement is as follows: the severity of the fire should be controlled such that the waste form container does not lose its structural integrity when handled (BSC 2004c [DIRS 171488], Section 6.2.2)

3. The definitions of the Safety Functions are provided in Appendix B.

4. Transportation casks must meet the flame emissivity and cask absorptivity requirements of 10 CFR 71.73(c)(4).

5. Analyses, as appropriate, will be performed on the respective cask/canister/waste form to demonstrate that the cask, canister, and/or waste form does not fail as a result of the credible fire in all areas where it is handled.

6. Analyses will confirm that sealed WPs shall withstand drops onto energy-absorbing crush pads without breaching and that the impact consequences associated with a drop of a canister or cask onto energy-absorbing crush pads shall be equal to, or less than, the impact consequences associated with the drop of a cask or canister from the maximum specified drop height onto an unyielding surface.

7. The naval SNF canister will not be exposed to fire conditions more severe than those corresponding to a black body gas exposure flux of 50 kW/ $\mathrm{m}^{2}$ and a temperature of $1000^{\circ} \mathrm{C}\left(1832^{\circ} \mathrm{F}\right)$ for 2 minutes. (BSC $2004 \mathrm{C}$ Sections 5.1.2.8 and 6.2.1.2.6)

\section{GENERAL NOTES:}

Lift height limits can be exceeded provided that energy-absorbing material is used to limit the impact energy to that of the drop height limit. The load drop probability includes components (lifting yokes, trunnions, and grapples) associated with the lifting and transferring of heavy loads.

The trolley system includes the trolley, rails, pedestal, and control system. 
The term cask refers to both the transportation cask and the site-specific cask, unless specified otherwise.

Every facility may not use every component listed for each system.

The term breach means an opening of the cask, canister, or WP initiating a Category 1 or Category 2 event sequence.

BDBGM = beyond design basis ground motion; CHF = Canister Handling Facility; DBGM = design basis ground motion; DPC = dual-purpose canister; DOE $=$ U.S Department of Energy; DTF = Dry Transfer Facility; FHF = Fuel Handling Facility; HAM = horizontal aging module; HLW = high-level radioactive waste; HVAC = heating, ventilation, and air-conditioning; HEPA = high-efficiency particulate air; ITWI = important to waste isolation; $\mathrm{MCC}=$ motor control center; $\mathrm{MCO}=$ multicanister overpack; MSC = monitored geologic repository site-specific cask; SC = safety category; SNF = spent nuclear fuel; SRTC = site rail transfer cart; SSC = structure, system, or component; SSCs = structures, systems, and components; TCRRF = Transportation Cask Receipt and Return Facility; UPS = uninterruptable power supply; WNNRF = Warehouse and Non-Nuclear Receipt Facility; WP = waste package. 


\section{B.1 General}

\section{APPENDIX B}

\section{DEFINITION OF SAFETY FUNCTIONS}

Each SSC that is ITS that is credited in the prevention or mitigation of a seismically initiated event sequence is assigned a safety function (or functions) with regard to performance goals for the specific SSC during and after the initiating seismic event. This appendix defines the safety functions used in this report. These definitions of safety functions were obtained from Seismic Analysis for Preclosure Safety (BSC 2004a [DIRS 171470], Section 4).

\section{B.1.1 Safety Function: No Structural Collapse}

The "no structural collapse" safety function is assigned to facilities and structures assigned to either a DBGM-1 or DBGM-2 level. For seismic margin calculations, the function corresponds approximately to the state of "large permanent distortion, short of collapse" of a structure or facility, termed Limit State A.

The "no structural collapse" safety function has the following performance goals during and after a seismic event:

- $\quad$ No structural collapse occurs (i.e., column and support members remain upright, beams remain functional, and walls remain standing), and failure of the contents is not serious enough to cause severe injury or death, prevent evacuation, or induce a breach of a waste container.

- Confinement of internal airflow is not required and may not be maintained. Concrete walls will remain standing, but may be extensively cracked; they may not maintain pressure differential with normal HVAC. Cracks will still provide a tortuous path for material release. The largest cracks are expected to be no greater than one-half in.

- $\quad$ Distortion of the structure will be limited, but expected to be visible to the naked eye.

- Components will remain anchored, but with no assurance that they will remain functional or easily repairable.

An additional requirement of this safety function is that the failure of adjacent structures and other SSCs (whether ITS or not) shall be considered in seismic analyses, as appropriate, and shall not induce collapse of the designated structure.

\section{B.1.2 Safety Function: No Drop}

The "no drop" safety function is assigned to cranes assigned to a DBGM-2 level. The no-drop safety function has the following performance goals during and after a seismic event: 
- $\quad$ The crane shall not release (or drop) a waste container or waste form either due to failure of crane components or controls due to a designated seismic event.

- $\quad$ The crane, as a system, shall not collapse or fall down. The crane shall remain on its track or guide system (regardless if crane is holding a waste container or waste form at the time of the event).

- Horizontal movement (swinging) of the cask or WP shall be restrained (if necessary) to preclude impacts with nearby walls and barriers.

- $\quad$ The crane track or guide system shall remain intact and attached to the structure. It may be distorted and bent, however.

- $\quad$ The crane shall not move in an uncontrolled manner or exceed its design speed limit.

\section{B.1.3 Safety Function: No Breach}

The "no breach" safety function is assigned to various waste containers assigned to either a DBGM-1 or DBGM-2 level.

The no breach (leak tight) safety function has the following performance goals during and after a seismic event:

- $\quad$ Containment of the waste form is maintained and no release or dispersement of radionuclides (either as gas or particulates) to the environment occurs.

- $\quad$ Distortion and damage of the container will be limited.

\section{B.1.4 Safety Function: No Tipover}

The "no tipover" safety function is assigned to various SSCs handling casks and canisters (e.g., turntables and pedestals) assigned to either a DBGM-1 or DBGM-2 level. The no tipover safety function has the following performance goal during and after a seismic event:

- The SSC shall not allow a tipover of a cask or canister (i.e., an overturn from an upright or normal position and impact the floor, ground, or other object), or tilting of the cask or canister resulting in an impact with an adjacent SCC that is ITS causing a domino effect.

\section{B.1.5 Safety Function: No Slapdown}

The "no slapdown" safety function is assigned to various SSCs handling casks and canisters (e.g., trolleys, WP transporters, transport locomotives, horizontal aging modules, site-specific cask transporters) assigned to either a DBGM-1 or DBGM-2 level. The no slapdown safety function has the following performance goals during and after a seismic event: 
- $\quad$ The SSC shall not allow a slapdown or rapid drop of a cask or WP in transit (i.e., the fall of a cask or WP, a vertical distance and subsequent impact onto the floor, ground, or onto another object).

- Any impacts to the cask or WP shall be within design specifications and, thereby, not induce a breach of the cask or WP in transit.

- $\quad$ The SSC itself may sustain substantial damage and may no longer be operable.

\section{B.1.6 Safety Function: No Release}

The "no release" safety function is assigned to staging and storage racks assigned to either a DBGM-1 or DBGM-2 level.

The no release safety function has the following performance goals during and after a seismic event:

- $\quad$ No release or dispersement of radionuclides (either as gas and/or as particulates) to the environment due to shaking or deformation of the waste form or storage rack.

- Distortion and damage of the waste form and rack(s) will be limited and will not preclude additional operations to retrieve the waste forms.

\section{B.1.7 Safety Function: No Failure}

The "no failure" safety function is assigned to various SSCs (e.g., limiters, collars, dampers) assigned to either a DBGM-1 or DBGM-2 level. The no failure safety function has the following performance goal during and after a seismic event:

- $\quad$ The SSC will continue its designated safety function after a seismic event without significant degradation in the performance or requirement for repair. For structural elements, the load response shall be essentially elastic due to the seismic event.

\section{B.1.8 Safety Function: No Significant Cracking/Displacement}

The "no significant cracking/displacement" safety function is assigned to aging pads at the DBGM-2 level. The no significant cracking/displacement safety function has the following performance goals during and after a seismic event:

- $\quad$ Aging pad is essentially intact. The concrete will remain structurally sound, but may contain several small cracks. The largest cracks are expected to be no greater than one-eighth in. and lengths shorter than $2 \mathrm{ft}$.

- $\quad$ Distortion of the pad will be very limited and not expected to be immediately apparent to the naked eye.

- Differential displacement across the pad shall be minimal, with differential displacements insufficient to cause a tipover of individual storage casks. 


\section{B.1.9 Safety Function: Controlled Failure}

The "controlled failure" safety function is assigned in special instances to SSCs (e.g., ventilation stacks) to preclude potential interactions with SSCs that are ITS. The controlled failure safety function has the following performance goals for ventilation stacks during and after a seismic event:

- $\quad$ Failure of an SSC due to a seismic event shall not obstruct an open flow path to the environment of the corresponding ventilation system.

- $\quad$ Failure of an SSC shall not impede the safety function of another SSC that is ITS.

\section{B.1.10 Safety Function: Shielding Integrity Remains Intact}

The "shielding integrity remains intact" safety function is assigned to shielding SSCs (e.g., shield view ports, shield windows, shield doors) at the DBGM-1 and DBGM-2 levels. The shielding integrity remains intact safety function has the following performance goals during and after a seismic event:

- $\quad$ The SSC remains essentially intact and in-place, and provides sufficient (direct shine) shielding to permit workers to egress the area without receiving a significant dose ("significant" is defined as less than 10 percent of the worker dose limit).

- $\quad$ Cracking of glass will be limited, and drainage of fluids (used in ports and windows for shielding) will be slow.

\section{B.1.11 Safety Function: Maintain Waste Form}

The "maintain waste form" safety function is assigned to fuel handling machines at either the DBGM-1 or DBGM-2 level. The maintain waste form safety function has the following performance goals during and after a seismic event:

- $\quad$ The SSC continues to maintain (retain) the waste form.

- $\quad$ The waste form remains intact and in-place.

- $\quad$ Damage to the waste form is minimal.

- $\quad$ Significant release or dispersement of radionuclides (either as gas and/or as particulates) to the environment due to shaking or deformation of the waste form is precluded. 


\section{B.1.12 Safety Function: No Criticality}

The "no criticality" safety function is assigned to various waste containers (e.g., casks, canisters, WPs) and staging and storage racks assigned to DBGM-2 level.

For various waste containers, the no criticality safety function has the following performance goals during and after a seismic event:

- The waste in the container shall remain nuclear subcritical as a result of a drop or impact within design limits with the most reactive credible configuration of the fissile material and moderation to the most reactive credible extent.

- The container internal geometry shall retain the design waste configuration with only minor damage/distortion.

For staging and storage racks, the no criticality safety function has the following performance goal during and after a seismic event:

- The rack shall remain structurally intact (with minimal distortion of the rack) and prevent bare fuel assemblies (or other exposed waste forms) to become nuclear critical as a result, considering the most reactive credible configuration of the fissile material and moderation to the most reactive credible extent.

\section{B.1.13 Safety Function: No Runaway}

The "no runaway" (uncontrolled descent) safety function is assigned to transporters and locomotives assigned to the DBGM-1 and DBGM-2 levels. The no runaway safety function has the following performance goals during and after a seismic event:

- $\quad$ The SSC shall stop the transport train (the trailer/car containing a waste form) after a seismic event (however, a tipover is not precluded).

- $\quad$ The SSC shall not allow the speed of the transport train to exceed its maximum allowable limits.

- The coupler shall remain connected between the locomotive and transport train.

\section{B.1.14 Safety Function: No Discharge}

The "no discharge" safety function is assigned to SSCs such as vent ducts, as well as HEPA filters and filter housings, which can contain a significant particulate dose and are assigned to either a DBGM-1 or DBGM-2 level.

For filters, the no discharge safety function has the following performance goals during and after a seismic event:

- No significant release or dispersement of radionuclides (particulates) to the immediate environment (to the structure interior or exterior) due to shaking of the 
filter and/or deformation of the filter (housing) system occurs. A significant release is defined as a release that results in less than a small fraction of the applicable dose limit over a period of 24 hours.

- No significant release or dispersement of radionuclides (particulates) back into the interior ventilation system (i.e., no back flow); this shall be precluded by valves/dampers or other appropriate devices.

- External components of the system (e.g., housings and fans) shall be rigidly anchored to major building elements (walls, floors, partitions).

- The system shall maintain its structural integrity, and distortion/damage of the housing and hangers (if applicable) will be limited.

For vent ducts, the no discharge safety function has the following performance goals during and after a seismic event:

- No significant release or dispersement of radionuclides (particulates) to the immediate environment. A significant release is defined as a release that results in less than a small fraction of the applicable dose limit over a period of 24 hours, and analyses shall consider potential accumulations within the duct re-entering the air stream.

- The duct shall maintain effective confinement of internal airflow with minimal outflow through joints.

- The duct shall maintain its structural integrity, and distortion/damage of the duct and hangers will be limited.

\section{B.1.15 Safety Function: No Derailment}

The "no derailment" safety function is assigned to trolley rails and rail tracks, which are assigned to either a DBGM-1 or DBGM-2 level.

The no derailment safety function has the following performance goals during and after a seismic event:

- $\quad$ No significant structural deformation of the rail occurs (i.e., the rails will not shear, heave, or warp) that is serious enough to cause a derailment or tipover of any waste transporter on the rail (e.g., WP trolley).

- $\quad$ No significant failure of the rail occurs (e.g., shearing, separation) that could induce a derailment if a transporter would pass over the damaged section.

- Distortion of the rail will be limited and not expected to be immediately apparent to the naked eye. 
- The rail will remain, for the most part, anchored and functional (or easily repairable).

- $\quad$ The rail system shall not impede the braking of any waste transporter on the rail.

\section{B.1.16 Safety Function: No Fall Down}

The "no fall down" safety function is assigned to large equipment (spent fuel handling machines, welders) that could impact SSCs if the specific equipment loses its anchorage and falls due to a seismic event. These SSCs can be assigned to either a DBGM-1 or DBGM-2 level.

The no fall down safety function has the following performance goals during and after a seismic event:

- $\quad$ The equipment, as a system, shall not collapse or fall down. The equipment shall remain on its track/guide system (if present).

- Anchorage for the equipment shall maintain the equipment in-place.

\section{B.1.17 Safety Function: No Loss of Confinement}

The "no loss of confinement" safety function is assigned to facilities and structures assigned to either a DBGM-1 or DBGM-2 level where structural integrity and confinement after the seismic event must be credited for compliance or added for defense-in-depth. For seismic margin calculations, the function corresponds to the state of limited permanent distortion of a structure or facility, termed Limit State C.

In the present dose consequence analysis, no credit is taken for confinement for limiting offsite dose to the public and, thereby, this safety function is not used. This definition was added for completeness.

The no loss of confinement safety function has the following performance goals during and after a seismic event:

- $\quad$ No structural collapse occurs (i.e., column and support members remain upright, beams remain functional, and walls remain standing), and failure of contents is not serious enough to cause severe injury or death, prevent evacuation, or induce a breach of a waste container.

- Confinement of internal airflow is required and will be maintained. Concrete walls will remain standing, but may be cracked. This cracking however, is small enough to maintain the pressure differential with normal HVAC. The largest cracks are expected to be no greater than approximately one-eighth in.

- Distortion of the structure will be very limited and not expected to be immediately apparent to the naked eye.

- Components will remain anchored and functional or easily repairable. 
An additional requirement of this safety function is that the failure of adjacent structures and other SSCs (whether safety-related or not) shall be considered in seismic analyses as appropriate and shall not induce collapse of the designated structure. 


\section{APPENDIX C}

\section{LIFT HEIGHT LIMITS FOR CASKS AND CANISTERS}

The various casks, canisters, and WPs to be handled in the repository surface facilities shall be lifted by the various cranes in these facilities in accordance with the limits specified in Table C-1.

Table C-I. Lift Height Limits

\begin{tabular}{|c|c|c|c|}
\hline Confinement & Contents & Lift Height Limit(s) (Note 1) & Reference \\
\hline $\begin{array}{l}\text { Transportation cask } \\
\text { with impact limiters }\end{array}$ & Any waste form & $\begin{array}{l}30 \mathrm{ft} \text { in the worst orientation above an } \\
\text { essentially unyielding flat surface }\end{array}$ & BSC 2005b Section 4.2.1 \\
\hline \multirow[t]{3}{*}{$\begin{array}{l}\text { Transportation cask } \\
\text { without impact } \\
\text { limiters; }\end{array}$} & DOE MCO & $\begin{array}{l}2 \mathrm{ft} \text { in any orientation above an } \\
\text { essentially unyielding flat surface unless } \\
\text { impact absorption feature is credited }\end{array}$ & $\begin{array}{c}\text { BSC 2005b Sections 5.1.1.18, } \\
4.2 .2\end{array}$ \\
\hline & Naval SNF Canister & $\begin{array}{l}16 \mathrm{ft} \text { in any orientation above an } \\
\text { essentially unyielding flat surface }\end{array}$ & BSC 2005b Section 5.1.1.18 \\
\hline & Any other waste form & $\begin{array}{l}23 \mathrm{ft} \text { in any orientation above an } \\
\text { essentially unyielding flat surface }\end{array}$ & BSC 2005b Section 5.1.1.18 \\
\hline Site-specific cask & $\begin{array}{l}\text { Commercial SNF or } \\
\text { DPC }\end{array}$ & $\begin{array}{l}23 \mathrm{ft} \text { in any orientation above an } \\
\text { essentially unyielding flat surface }\end{array}$ & BSC 2005b Section 5.1.1.18 \\
\hline \multirow[t]{4}{*}{ Unconfined } & DPC & $\begin{array}{c}23 \mathrm{ft} \text { in vertical orientation from the floor } \\
\text { of the transportation cask or } \\
\text { site-specific cask } \\
\text { and } \\
\begin{array}{c}2 \mathrm{ft} \text { in vertical orientation above the floor } \\
\text { of the transfer cell }\end{array}\end{array}$ & BSC 2005b Section 5.1.1.43 \\
\hline & $\begin{array}{l}\text { Standardized DOE } \\
\text { SNF Canister }\end{array}$ & $\begin{array}{c}23 \mathrm{ft} \text { in any orientation above an } \\
\text { essentially unyielding flat surface } \\
\text { and } \\
2 \mathrm{ft} \text { in vertical orientation above the floor } \\
\text { of the transfer cell }\end{array}$ & $\begin{array}{c}\text { BSC 2005b Sections 5.1.1.14, } \\
4.2 .2\end{array}$ \\
\hline & DOE MCO & $\begin{array}{c}23 \mathrm{ft} \text { in vertical orientation ( } 3 \text { degrees or } \\
\text { less off vertical) onto an essentially flat } \\
\text { unyielding surface } \\
\text { and } \\
2 \mathrm{ft} \text { in any orientation above an } \\
\text { essentially unyielding flat surface }\end{array}$ & $\begin{array}{c}\text { BSC 2005b Sections 5.1.1.15, } \\
4.2 .2\end{array}$ \\
\hline & DOE HLW Canister & $\begin{array}{c}23 \mathrm{ft} \text { in vertical orientation above the } \\
\text { floor of a cask, WP, staging rack or } \\
\text { staging pit } \\
\text { and } \\
2 \mathrm{ft} \text { in vertical orientation above the floor } \\
\text { of the transfer cell }\end{array}$ & BSC 2005b Section 5.1.1.24 \\
\hline
\end{tabular}


Table C-I. Lift Height Limits (Continued)

\begin{tabular}{|c|c|c|c|}
\hline Confinement & Contents & Lift Height Limit(s) (Note 1) & Reference \\
\hline $\begin{array}{l}\text { Unconfined } \\
\text { (continued) }\end{array}$ & Naval SNF Canister & $\begin{array}{c}28 \mathrm{ft} \text { in vertical orientation above the } \\
\text { floor of a cask or WP } \\
\text { and } \\
2 \mathrm{ft} \text { in vertical orientation above the floor } \\
\text { of the transfer cell }\end{array}$ & BSC 2005b Section 5.1.1.42 \\
\hline \multirow[t]{2}{*}{$\begin{array}{l}\text { Waste package } \\
\text { (sealed; trunnion } \\
\text { collars installed) }\end{array}$} & $\begin{array}{l}\text { Naval Long SNF } \\
\text { Canister }\end{array}$ & $\begin{array}{c}3.3 \mathrm{ft} \text { in vertical orientation onto an } \\
\text { essentially unyielding flat surface } \\
\text { and } \\
1.6 \mathrm{ft} \text { for tipover from an elevated } \\
\text { surface onto an essentially unyielding } \\
\text { flat surface }\end{array}$ & $\begin{array}{c}\text { BSC 2005b Sections 5.1.3.12 } \\
\text { and 5.1.3.9 }\end{array}$ \\
\hline & Any waste form & $\begin{array}{c}7.8 \mathrm{ft} \text { in a horizontal orientation onto an } \\
\text { essentially unyielding flat surface } \\
\text { and } \\
6.5 \mathrm{ft} \text { in a vertical orientation onto an } \\
\text { essentially unyielding flat surface } \\
\text { (except naval long WP) } \\
\text { and } \\
6.5 \mathrm{ft} \text { for tipover from an elevated } \\
\text { surface onto an essentially unyielding } \\
\text { flat surface (except naval long WP) }\end{array}$ & $\begin{array}{c}\text { BSC 2005b Sections 5.1.3.12 } \\
\text { and 5.1.3.9 }\end{array}$ \\
\hline $\begin{array}{l}\text { Waste package } \\
\text { (sealed; on } \\
\text { emplacement pallet; } \\
\text { trunnion collars not } \\
\text { installed) }\end{array}$ & Any waste form & $\begin{array}{l}6.5 \mathrm{ft} \text { from bottom of the pallet to an } \\
\text { essentially unyielding flat surface, in a } \\
\text { horizontal orientation }\end{array}$ & $\begin{array}{c}\text { BSC 2005b Sections 5.1.3.8 } \\
\text { and 5.1.3.12 }\end{array}$ \\
\hline \multirow{3}{*}{$\begin{array}{l}\text { Waste package } \\
\text { (unsealed) }\end{array}$} & DOE MCO & $\begin{array}{l}2 \mathrm{ft} \text { in any orientation above an } \\
\text { essentially unyielding flat surface }\end{array}$ & $\begin{array}{c}\text { BSC 2005b Sections 5.1.1.52, } \\
4.2 .2\end{array}$ \\
\hline & Naval SNF Canister & $\begin{array}{l}2 \mathrm{ft} \text { in any orientation above an } \\
\text { essentially unyielding flat surface }\end{array}$ & $\begin{array}{c}\text { BSC 2005b Sections 5.1.1.52, } \\
5.1 .1 .18\end{array}$ \\
\hline & Any other waste form & $\begin{array}{l}23 \mathrm{ft} \text { in any orientation above an } \\
\text { essentially unyielding flat surface }\end{array}$ & BSC 2005b Section 5.1.1.52 \\
\hline
\end{tabular}

Note 1: These lift height limits can be exceeded if an appropriate impact absorption feature is credited 